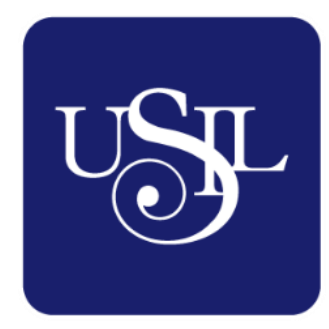

UNIVERSIDAD

SAN IGNACIO

DE LOYOLA

ESCUELA DE POSTGRADO

Maestría en Diseño Gráfico

\title{
DISEÑO DE INFORMACIÓN APLICADO EN UN CORTO DOCUMENTAL COMO HERRAMIENTA DE DIFUSIÓN SOBRE EL PELIGRO DE EXTINCIÓN DE LA LENGUA UCHINAAGUCHI ENTRE LOS DESCENDIENTES DE OKINAWENSES EN EL PERÚ
}

Tesis para optar el grado de Maestro en Diseño Gráfico

\section{GERARDO IGEI KOHATSU}

Asesor:

Mg. Antonio Javier Martinench Lozano

Lima - Perú

2020 


\section{Dedicatoria/Agradecimientos}

A mi esposa, Andrea, quien me enseña a diseñar la vida con el amor.

A mis padres y hermanos, en quienes encuentro motivación y fuerza.

A mi asesor, Antonio, por su paciencia y dedicación en este proyecto.

A mis abuelos, por quienes busco hacer algo por la lengua en la que cantaban y conversaban.

A Dios y a la Virgen, por darme oportunidades como ésta para ser una mejor versión de mí. 


\section{Resumen}

El uchinaaguchi es una de las lenguas de la prefectura japonesa de Okinawa y se encuentra en un proceso de transmisión intergeneracional estancado. Sin embargo, esto se da no solo en dicho archipiélago, sino que tiene mayor fuerza de Japón. Por ello, se realiza el presente estudio en Perú, donde los jóvenes de origen okinawense van perdiendo el interés por sus raíces. Partiendo desde ese enfoque, el objetivo del presente estudio es analizar cómo la falta de transmisión y conservación de su lengua materna ocasiona una amenaza de extinción del idioma uchinaaguchi entre los descendientes en el Perú. Por tal motivo, la pregunta de investigación es: ¿Que pérdidas culturales son generadas por el desconocimiento del idioma uchinaaguchi? Para poder aproximarse a los resultados se utilizó una metodología mixta, basada en un enfoque cualitativo (entrevistas, observación y etnografía); y un enfoque cuantitativo (encuestas). Las respuestas muestran un actual desconocimiento sobre la lengua uchinaaguchi a pesar de la cercanía que muchos de los encuestados (becarios) puedan sentir en relación a Okinawa. Por ello se propone implementar una metodología para utilizar el diseño de información en un documental. Esta herramienta permitirá elevar el interés de los espectadores para conocer más sobre el tema y tomar acciones para mejorar la situación de peligro en la que se encuentra el uchinaaguchi.

\section{Palabras clave:}

Diseño de información, metodología, infografía, uchinaaguchi 


\begin{abstract}
Uchinaaguchi is one of the languages of the Japanese prefecture of Okinawa and is in a stagnant process of intergenerational transmission. However, this occurs not only in said archipelago, but it has greater strength outside Japan. For this reason, the present study is carried out in Peru, where young people of Okinawan origin are losing interest in their roots. Starting from this approach, the objective of this study is to analyze how the lack of transmission and conservation of their mother tongue causes a threat of extinction of the Uchinaaguchi language among descendants in Peru. For this reason, the research question is: What cultural losses are generated by the lack of knowledge of the Uchinaaguchi language? In order to approximate the results, a mixed methodology was used, based on a qualitative approach (interviews, observation and ethnography); and a quantitative approach (surveys). The answers show a current lack of knowledge about the Uchinaaguchi language despite the closeness that many of the respondents may feel in relation to Okinawa. For this reason, it is proposed to implement a methodology to use the design of information in a documentary. This tool will increase the interest of viewers to learn more about the subject and take actions to improve the situation of danger in which the uchinaaguchi finds itself.
\end{abstract}

\title{
Keywords:
}

Information design, methodology, infography, Uchinaaguchi 
Tabla de contenidos

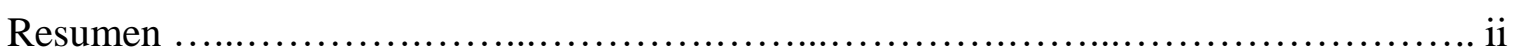

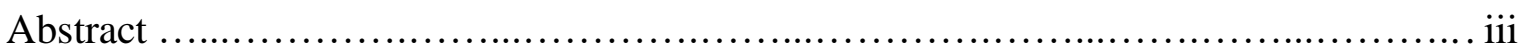

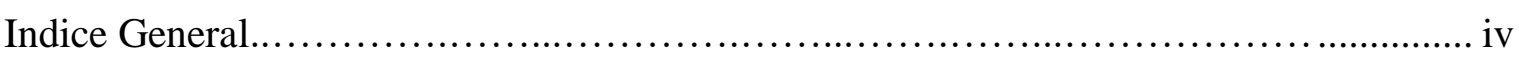

Lista de Cuadros/ Tablas ..................................................... vii

Lista de Figuras ............................................................ viii

Lista de Imágenes.......................................................

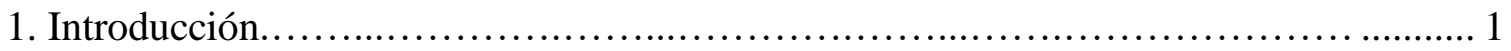

1.1. Descripción del problema................................................ 1

1.2 Pregunta de investigación............................................. 5

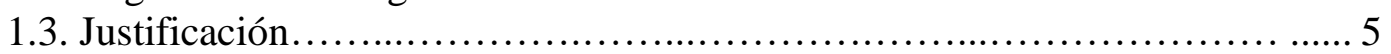

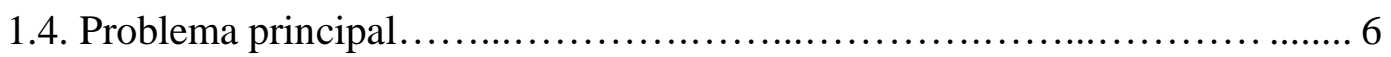

1.5. Problema secundario.............................................................. 6

1.6. Objetivo principal................................................... 6

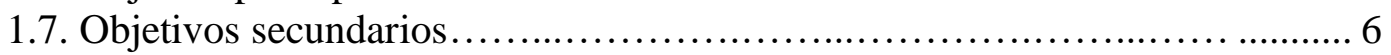

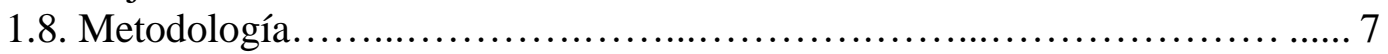

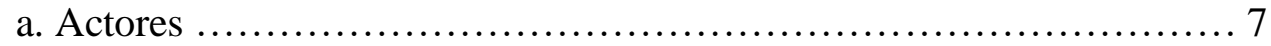

- Mapa de actores......................................... 7

b. Campo ....................................................... 10

- Asociación Okinawense del Perú (AOP) ........................... 10

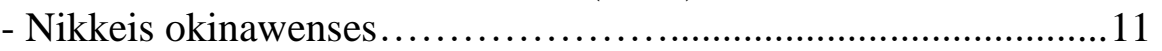

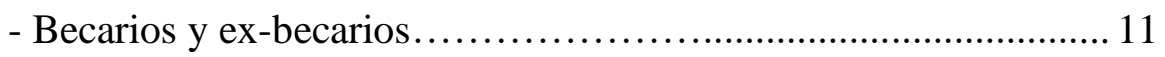

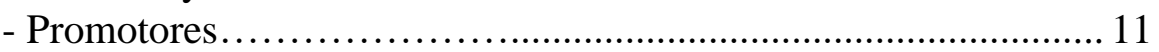

- Espacios digitales...................................................... 12

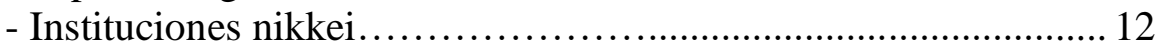

c. Método............................................................... 13

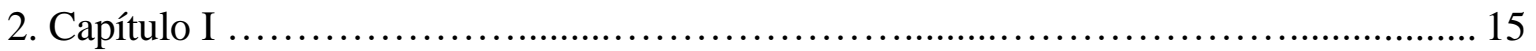

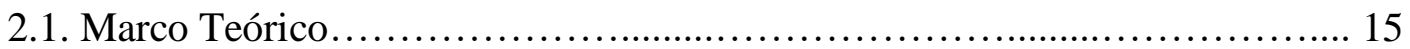

A. Lengua materna..................................................... 15

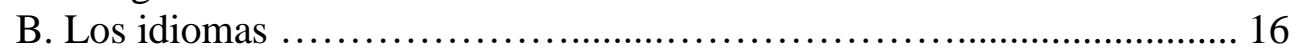

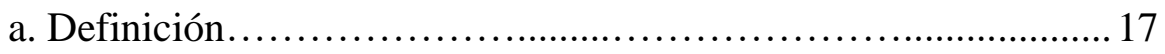

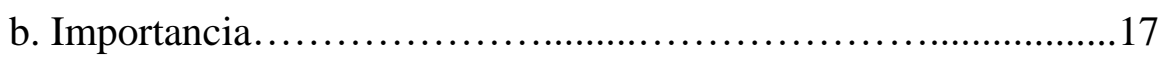

c. Clasificación según su uso....................................... 18

C. Los idiomas en peligro de extinción.......................................... 20

D. ¿Qué se pierde además de la lengua? ...................................... 23

a. El lenguaje y las expresiones culturales......................... 24

- El lenguaje y la música (canciones, danzas) ..............24

- El lenguaje y la cosmovisión................................. 25

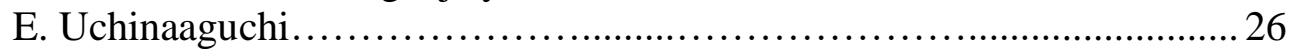

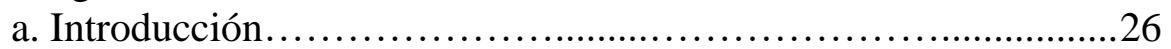

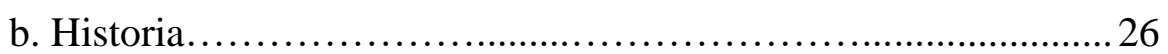

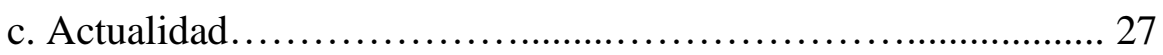

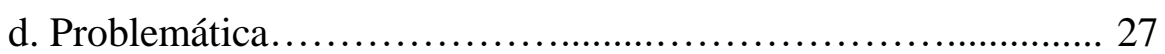

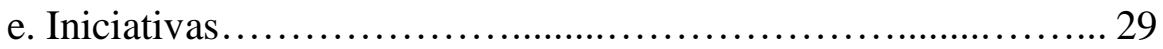

F. Uchinaaguchi en Perú.................................................. 30

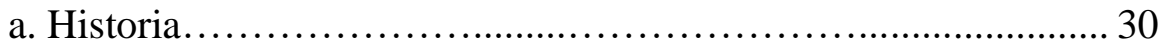

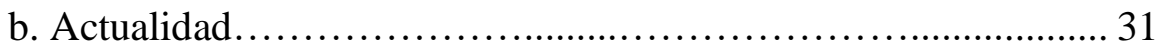


c. Problemática......................................................... 31

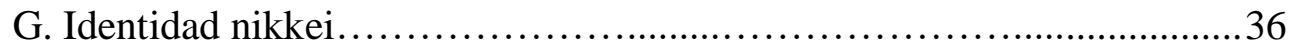

a. Issei (migrantes japoneses) ..................................... 36

b. Nisei (segunda generación) .................................. 36

c. Sansei (tercera generación) .................................. 37

d. Yonsei (cuarta generación) ................................. 37

H. Descendientes de Okinawa en Perú................................. 38

a. Conexión con las raíces...................................... 38

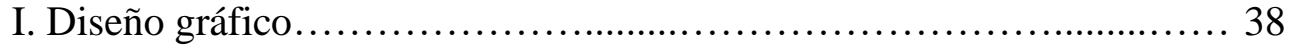

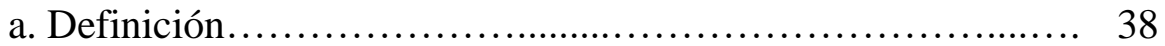

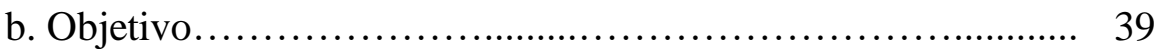

c. Metodología ............................................. 41

J. Semiótica en el diseño............................................ 42

a. Definición ..................................................... 42

b. Objetivo................................................... 44

c. Elementos del diseño...................................... 45

- Imagen y texto........................................ 45

- Color ............................................. 46

- Tipografía............................................. 47

- Formas .............................................. 49

K. Diseño de información........................................... 50

a. Definición................................................. 50

b. Importancia................................................. 51

c. Características............................................ 52

d. Utilización............................................. 53

L. Documental.................................................... 53

a. Definición.............................................. 53

b. Metodología............................................... 54

2.2. Estado del Arte........................................................... 54

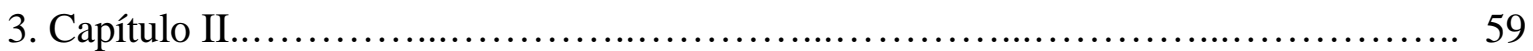

3.1. Análisis del público objetivo............................................. 59

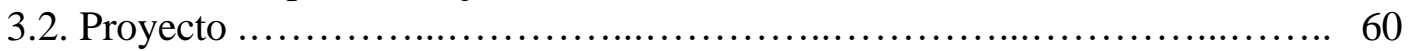

3.3. Proceso del proyecto................................................ 61

A. Concepto ................................................... 61

B. Nombre del proyecto ........................................... 63

C. Identidad de marca .............................................. 63

a. ADN de Marca .............................................. 63

b. Fuerza Marca .................................................. 64

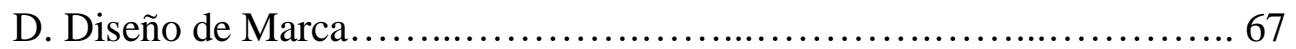

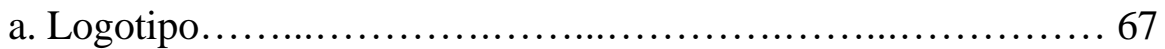

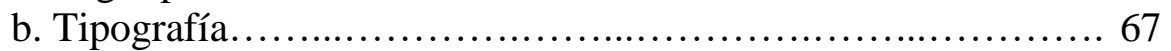

c. Color......................................................... 68

d. Prisma Kapferer ........................................... 69

E. Fundamentación del proyecto .................................... 69

3.4. Diseño de la comunicación.............................................. 70

A. Receptor ........................................................... 72

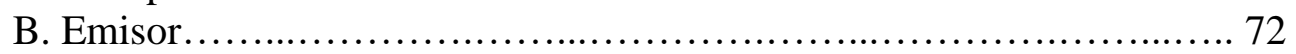

C. Canales y medios................................................... 73

D. Mensaje............................................................... 73 
3.5. Estudio de la comunicación ............................................... 73

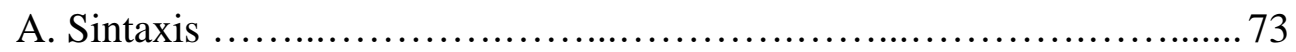

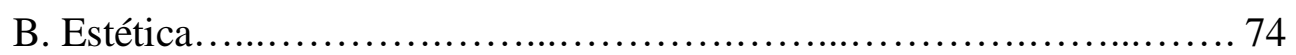

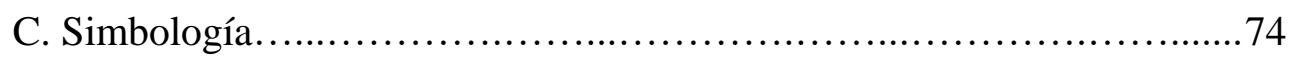

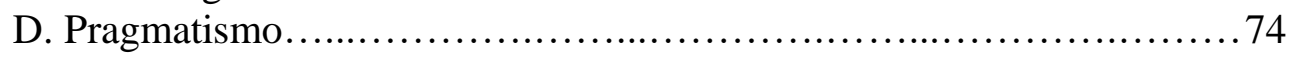

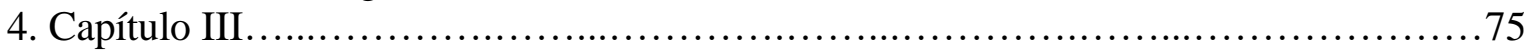

A. Introducción .................................................. 75

B. Presentación de propuesta de diseño.............................. 76

C. Evaluación de pares .............................................. 81

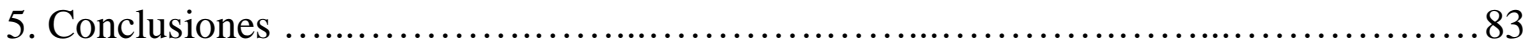

6. Recomendaciones...................................................................... 85

7. Referencias Bibliográficas .................................................. 86

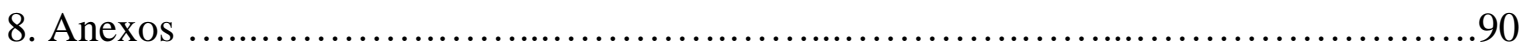




\section{Lista de Cuadros/ Tablas}

Cuadro 1. Mapa de actores relacionado al uchinaaguchi en el Perú y en espacios digitales

Cuadro 2. Actores, campo, repertorios y herramientas alrededor del uchinaaguchi en el Perú 


\section{Lista de Figuras e Imágenes}

Figura 1. ¿Cuántas palabras o frases conoces en Uchinaaguchi?

Figura 2. Lo que sabes de uchinaaguchi, ¿dónde lo aprendiste?

Figura 3. ¿Escuchaste a alguien hablar uchinaaguchi en tu casa?

Figura 4. ¿En qué situación piensas que podría estar, según la clasificación de la UNESCO para las lenguas en peligro de extinción?

Figura 5. Si supieras que se encuentra en peligro de desaparecer en algunos años, ¿te gustaría poder aprender algo de ella?

Figura 6. Actualmente, ¿cuál es tu grado de identificación con Okinawa? (1: no muy identificado / 5: muy uchinanchu)

Figura 7. ¿Conoces personas que dominen este idioma en Okinawa?

Figura 8. ¿Conoces personas que dominen este idioma en Perú? 


\section{Lista de Imágenes}

Imagen 1. Moodboard de imágenes de Okinawa

Imagen 2. Logotipo del proyecto

Imagen 3. Construcción del logotipo

Imagen 4. Colores que expresan la esencia cromática de Okinawa

Imagen 5. Prisma Kapferer aplicado a la marca

Imagen 6. Fórmula para utilizar diseño de información en un documental

Imagen 7. Uchinaaguchi en peligro, infografía final de la categoría "qué"

Imagen 8. Causas de su pérdida en el Perú, infografía final de la categoría "por qué" Imagen 9. Aprende uchinaaguchi, infografía final de la categoría "cómo" 


\section{Introducción}

En 1906 llegaron los primeros migrantes okinawenses al Perú. Ha pasado más de un siglo y estos viajeros juntos con sus descendientes, han vivido un proceso de asentamiento. Durante este tiempo, la comunidad buscó mantenerse unida con el fin de conservar sus tradiciones, costumbres y las enseñanzas de sus ancestros, por lo que fue bastante cerrada, teniendo actividades artísticas, deportivas y educativas al estilo okinawense; se preparaban las comidas típicas y se comunicaban en japonés o uchinaaguchi.

A medida que pasaban las generaciones, los descendientes fueron sintiéndose cada vez más peruanos, como es natural, y se produjo un desinterés por la cultura heredada y, sobretodo, una desconexión con el idioma uchinaaguchi, lengua materna de sus ancestros. Esto ha ocasionado que en nuestro país cada vez hayan menos personas que utilicen y conozcan este idioma, en consonancia a lo que sucede en el mundo, donde se encuentra en peligro de extinción.

\subsection{Descripción del problema}

En los próximos 80 años, se espera que se pierdan al menos 3000 idiomas (UNESCO, 2014). Cada una de estas desapariciones no solo derrumbará un puente con un sistema lingüístico sino que implicará la pérdida de una cosmovisión, de una filosofía de vida, de ciertos valores particulares, de narraciones populares, de una expresión cultural característica. Muchas leyendas, historias, frases y sus significados más profundos se vuelven irrecuperables; se debilita en gran medida la identidad.

Por este motivo, la UNESCO ha analizado idiomas a nivel mundial clasificándolos, según el uso que tengan, por medio del Atlas de las lenguas en peligro de extinción. Allí uno puede encontrar información sobre si está a salvo, es vulnerable, está en peligro, seriamente en peligro, en situación crítica o ya se encuentra extinta (UNESCO, 2014). La preocupación es grande en estos términos, pues hay varias lenguas que quizás no duren muchos años si no 
se hace algo al respecto. Entre ellas se encuentra el uchinaaguchi, que es oriunda de Okinawa, donde la usan unas 400000 personas (Wikitongues, s.f.). Sin embargo, existe una crisis generacional en el uso del idioma en el mismo archipiélago: la población que lo considera como un idioma vivo es mayor de 75 años; aquellos que lo entienden y lo usan poco tienen entre 45 y 75 años, mientras que los menores a 45 usan solo el japonés (Curry, Hijirida \& Serafim, 2009). El problema surge cuando no existe un interés por el idioma, la cultura, ni la identidad; va pasando el tiempo y aquellos que hablan fluidamente la lengua irán muriendo.

Sin embargo, en los últimos años en Okinawa existe un interés por no perder el uchinaaguchi manifestado en iniciativas en el ámbito de educación (Hijirida \& Oshiro, 2010; Sakihara, 2006; Shimabukuro, 2014), en los medios de comunicación (radios, programas de TV, etc.), en las redes sociales (páginas de Facebook, canales de YouTube, etc.), en el arte (producciones musicales, obras teatrales, etc.), entre otros. Por otro lado, en Hawai también existen varias iniciativas (cursos, escritos, centros de estudios okinawenses, etc.) que fomentan el conocimiento y uso del idioma. No obstante, más allá de estos dos lugares, no hay mucha preocupación por la recuperación del idioma entre sus descendientes (Argentina, Brasil, Bolivia, EEUU, etc.).

Aprender este idioma en particular, implica un reto para todos aquellos que quieran hacerlo en Perú, pues tendrían que estudiar principalmente japonés para comprender la mayoría de los libros o programas que existen, o inglés para estudiar con las oportunidades que brindan en Hawai.

Actualmente en nuestro país, existe una fuerte presencia de nikkei (personas de ascendencia japonesa) cuyo origen es la prefectura de Okinawa (se aproxima entre el 50 y el 70\%). Para los primeros migrantes (issei), mantenerse unidos y utilizar su lengua era un deseo muy fuerte pues de este modo sentían que seguían arraigados con su tierra natal. 
Además, un motivo importante fue que ellos tenían la esperanza de volver a Okinawa luego de juntar dinero, pues el motivo de la migración fue que este archipiélago se encontraba en profunda pobreza y no había muchas oportunidades.

Sin embargo, este deseo de conservación del idioma se fue desvaneciendo por diversos motivos. El primero es que durante la segunda guerra mundial, los japoneses fueron perseguidos, sus locales saqueados, y prohibidos de tener escuelas propias. Esto produjo que los nikkei en general, no pudieran aprender formalmente el japonés como se debe (salvo en algunas escuelas clandestinas que surgieron). Esto los fue desligando de sus raíces en un contexto difícil. Una vez terminado el conflicto bélico, los issei vieron que ya no sería oportuno volver a Japón porque era un país que había recientemente perdido una guerra y estaba devastado. Por ese motivo, decidieron quedarse, lo cual implicaba dejar de lado todo lo que estaba relacionado a volver, como mantener la lengua nativa o el sistema educativo japonés, que luego seguirían usando una vez en el país del sol naciente.

Fue así que aprender el español se volvió una prioridad. De esta manera, fue más común ver que los nikkei tenían nombres en español, comenzaron a adaptarse a la cultura local, ser más abiertos con los vecinos, y a hacer su vida sabiendo que éste sería definitivamente su nuevo hogar. Además, aprender español era un elemento importante para poder surgir dentro de la sociedad y sacar adelante a su familia. Por ello, hasta los isseis comenzaron a comunicarse con sus hijos en un español sencillo. Poco a poco había menos interés en el idioma, tanto japonés (que lo aprendían en una educación formal en sus escuelas antes de la guerra) como el uchinaaguchi (con la que se comunicaban en casa).

Por otro lado, la tercera generación (sansei) ya no tiene muy en cuenta sus raíces orientales, puesto que se sienten muy peruanos. Debido a eso, ha resultado complicado para sus padres fomentar en ellos el deseo de conocer o continuar las tradiciones, porque les resultan ajenas o aburridas, en muchos casos. Muchos de ellos han vivido con sus abuelos 
japoneses, de quienes aprendieron palabras básicas en uchinaaguchi para usar en casa (mezcladas con japonés, sin saber cuál pertenecía a cuál), las canciones en esa lengua, las costumbres y las enseñanzas cargadas con la sabiduría de ese pueblo.

Cabe destacar que desde hace aproximadamente 30 años, se vienen realizando intercambios culturales con Okinawa, enviando jóvenes de Perú, Argentina, Brasil, Bolivia y otros países a que tengan experiencias con la tierra de sus ancestros, así como estrechar los lazos con los familiares que tienen allá. Estas becas, dentro de sus programas, cuentan con clases de idioma japonés, danza, música, karate, pintura al estilo okinawense, entre otras manifestaciones culturales. Al volver de Japón, muchos han comenzado a enseñar lo que han aprendido, teniendo bastante acogida entre sus contemporáneos. Se vive, de algún modo, un despertar de la cultura okinawense entre los jóvenes de la colectividad. Sin embargo, no ha pasado así con la lengua.

En nuestro país ha habido algunas iniciativas para fomentar el idioma. Por ejemplo, en el año 2018, la voluntaria japonesa de JICA (Japan International Cooperation Agency), Lima Tokumori, reconoció que este desinterés por la lengua uchinaaguchi era a su vez impulsado por las faltas de oportunidades que tienen los descendientes para poder aprenderlo o practicarlo. Ella preparó un curso de este idioma, con materiales impresos y apoyo audiovisual. Tuvo acogida entre algunos miembros de la colectividad que mostraron su interés con su presencia y participación. Sin embargo, hay mucho más por hacer para poder captar el interés y la atención, sobretodo, de las nuevas generaciones. Ésta es una tarea de recuperar el uso, al menos básico, del idioma, que tendrá su repercusión en el interés en la cultura desde una nueva perspectiva. Cuántas veces habremos "cantado" una melodía en otro idioma sin saberlo, solo porque suena bien, sin comprender su significado. Del mismo modo, las canciones, los proverbios, las frases en uchinaaguchi tienen un mensaje, que es importante conocerlo. 
Si no se hace nada al respecto se puede caer en lo que dice un proverbio de Okinawa: Umarejima nu kutuba washinnee, kunin washun (si olvidas la lengua de tu tierra natal, olvidarás también a tu tierra natal).

\subsection{Pregunta de investigación}

¿Que pérdidas culturales son generadas por el desconocimiento del idioma uchinaaguchi?

La extinción de un idioma se da cuando muere la última persona que tiene esa lengua como materna. Pero no solamente se pierde el modo de comunicación de una comunidad, sino que se relaciona con otros aspectos que hay que tomar en cuenta: la cultura, los significados de las canciones y manifestaciones artísticas, la sabiduría de sus refranes, su gastronomía, su espiritualidad, su riqueza social, sus saberes en general; comienza un proceso de congelamiento en el tiempo. Cada idioma tiene su forma de conceptualizar ideas. Hay lenguas que tienen palabras que no se pueden traducir, y eso les otorga una riqueza particular. Esto se ve manifestado en sus expresiones culturales y es la lengua la que tiene la facultad de dar un verdadero sentido a todo esto, pues le da el significado a la cosmovisión.

\subsection{Justificación}

La elección de este tema nace de la experiencia de haber viajado a Okinawa y notar cómo este idioma se está olvidando entre los habitantes de este archipiélago. A modo personal, representa la cultura de mis ancestros y su extinción significaría una desconexión para mi familia y mis raíces. Por ello, la preocupación de conocer el problema, para poder enfrentarlo desde el ámbito académico y del diseño. En el campo académico, al ser un tema poco abordado, permitirá recopilar información de diferentes fuentes para poder realizar estudios que permitan plantear otras soluciones al problema de la pérdida de este idioma.

A nivel social, su extinción implicaría la pérdida de una gran riqueza cultural, puesto que se perderían muchos significados, sabiduría popular, cosmovisión, etc. Es por ello que 
resulta crucial emprender una investigación para poder enriquecer el corpus, así como preparar el campo para futuros estudios.

\subsection{Problema principal}

¿La falta de transmisión y conservación de su lengua materna ocasiona una amenaza de extinción del idioma uchinaaguchi entre los descendientes de okinawenses en el Perú?

\subsection{Problema secundario}

¿La falta de transmisión y conservación de su lengua materna ocasiona una amenaza de extinción del idioma uchinaaguchi entre los descendientes de okinawenses en el Perú originando una pérdida de la riqueza musical?

¿La falta de transmisión y conservación de su lengua materna ocasiona una amenaza de extinción del idioma uchinaaguchi entre los descendientes de okinawenses en el Perú originando una pérdida de tradiciones orales?

\subsection{Objetivo principal}

Analizar la falta de transmisión y conservación de su lengua materna ocasiona una amenaza de extinción del idioma uchinaaguchi entre los descendientes de okinawenses en el Perú

\subsection{Objetivos secundarios}

Evidenciar la falta de transmisión y conservación de su lengua materna ocasiona una amenaza de extinción del idioma uchinaaguchi entre los descendientes de okinawenses en el Perú originando una pérdida de la riqueza musical

Demostrar la falta de transmisión y conservación de su lengua materna ocasiona una amenaza de extinción del idioma uchinaaguchi entre los descendientes de okinawenses en el Perú originando una pérdida de tradiciones orales

\subsection{Metodología}




\section{a. Actores}

\section{UCHINAAGUCHI うちなーぐち}

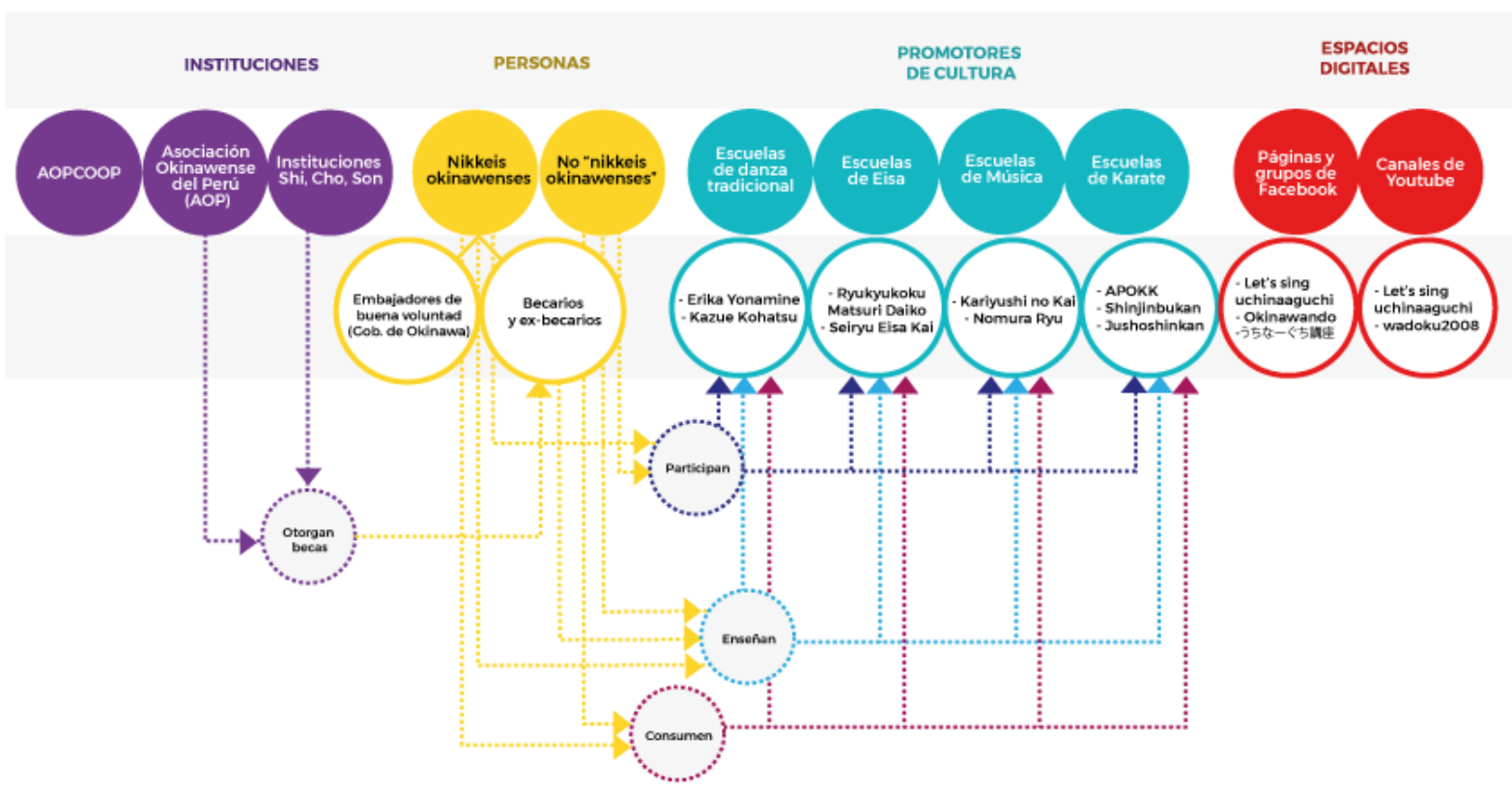

Cuadro 1. Mapa de actores relacionado al uchinaaguchi en el Perú y en espacios digitales

\section{- Mapa de actores}

Según el mapa de actores realizado, podemos encontrar 4 grupos:

instituciones, personas, promotores culturales y espacios digitales. Dentro de los más involucrados hallamos en primer lugar a la Asociación Okinawense del Perú. Esta institución, fundada en 1911, reúne a esta colectividad en nuestro país y está integrada por unas cuarenta instituciones (Shi - Cho - Son) que a su vez tienen una administración autónoma. Uno de sus objetivos es mantener la confraternidad, así como difundir la cultura okinawense mediante diversas actividades y cursos.

Por otro lado, encontramos a los nikkei, de diferentes prefecturas de Japón (Okinawa, Yamaguchi, Kagoshima, Yamanashi, Kagawa, Fukushima, etc.). Aquí 
podemos distinguir a los descendientes de segunda generación (nisei) y a los de tercera y cuarta (sansei y yonsei, respectivamente).

Los nisei tienen aproximadamente de 60 años a más. La mayoría de ellos no habla japonés, por la clausura de las escuelas niponas durante la Segunda Guerra Mundial. Los que nacieron antes del conflicto culminaron solo la primaria, mientras que los demás tuvieron oportunidad de estudiar en la universidad, siendo la generación que revitalizó a la colectividad. Las carreras que más siguieron fueron ingeniería, medicina, contabilidad, arte. Durante la década de los 60's sufrieron una crisis de identidad pues no sabían si eran japoneses o peruanos. Algunos de ellos han escuchado a sus padres hablar en uchinaaguchi, por lo general entre ellos, por lo que podrían entender algunas cosas, pero no hablarlo.

A diferencia de otros países donde también hubo migración japonesa, en Perú se puede hablar de una transición generacional. A partir de la segunda guerra mundial se prohibió el ingreso de nipones al Perú, lo cual generó que el grupo generacional sea bastante homogéneo en edad, pensamiento, forma de actuar, etc. Esto permitió que el fenómeno nikkei tenga un proceso no tan conflictivo como sucedió en Argentina o Brasil que constantemente recibían issei, quienes disputaban en modos de pensar y actuar con los nisei, siendo incluso algunos nisei mayores que los recientes migrantes. Recién a partir de la década de los 60's se permitió el ingreso a japoneses que certifiquen que tenían familiares en Perú.

Por otro lado se encuentran los sansei y yonsei. Ellos tienen un escaso conocimiento del idioma uchinaaguchi pero han escuchado algunas palabras y frases en su casa de parte de sus abuelos o bisabuelos. Su sentido de peruanidad es muy fuerte, pues han nacido, vivido, estudiado y trabajado como sus 
compatriotas. Ellos no se ligan con Japón más que por algunas costumbres y rasgos físicos evidentes.

Dentro de ellos hay un grupo especial que son los becarios; en este caso serán quienes han tenido la oportunidad de viajar a Okinawa, despertándose en ellos el interés y cariño hacia la tierra de sus antepasados. Durante la estadía en este lugar han aprendido diversas manifestaciones culturales, y al volver, algunos han decidido enseñar para compartir sus experiencias, volviéndose difusores de Okinawa en nuestro país.

Asimismo, es bueno tener en cuenta a las personas que no son "nikkei okinawenses”. Esto incluye a los descendientes de japoneses de otras prefecturas, así como peruanos que no tienen ninguna relación familiar nipona. Ellos han conocido la cultura de Okinawa por medio de algún amigo, interesándose en algunos casos por aprenderla.

También está pasando cada vez con mayor frecuencia (lo que antes era considerado "casi prohibido" dentro de la colectividad), que hay matrimonios mixtos (nikkei con no nikkei). Los hijos, al no tener solo origen japonés, tienen un bagaje cultural más amplio, lo que por naturalidad hace que, usualmente, una de las raíces pierda fuerza.

En muchos casos los nikkeis okinawenses y los no okinawenses son muy cercanos en la actualidad, lo que no ocurría décadas atrás. La cultura de Okinawa, al tener mayoría de descendientes, ha tenido bastante impacto dentro de la sociedad peruana, y no resulta extraño que lo okinawense se exponga como cultura japonesa, y en algunos casos, hasta pueda ser considerado representativo (como podría pasar con el Eisa). 
Los promotores de la cultura okinawense tienen un papel muy importante en la colectividad. Mediante diversas escuelas, algunas de origen japonés y otras fundadas aquí, transmiten las artes de Okinawa y las mantienen vivas entre sus descendientes y simpatizantes. En estos grupos se aprenden canciones, bailes, y costumbres típicas de Okinawa. Por último, hay espacios digitales (iniciativas extranjeras) donde se difunde el uso del idioma, tanto en Facebook como en YouTube. Hay clases de uchinaaguchi, hay canciones didácticas para aprender, hay publicaciones relacionadas al idioma, etc.

\section{b. Campo}

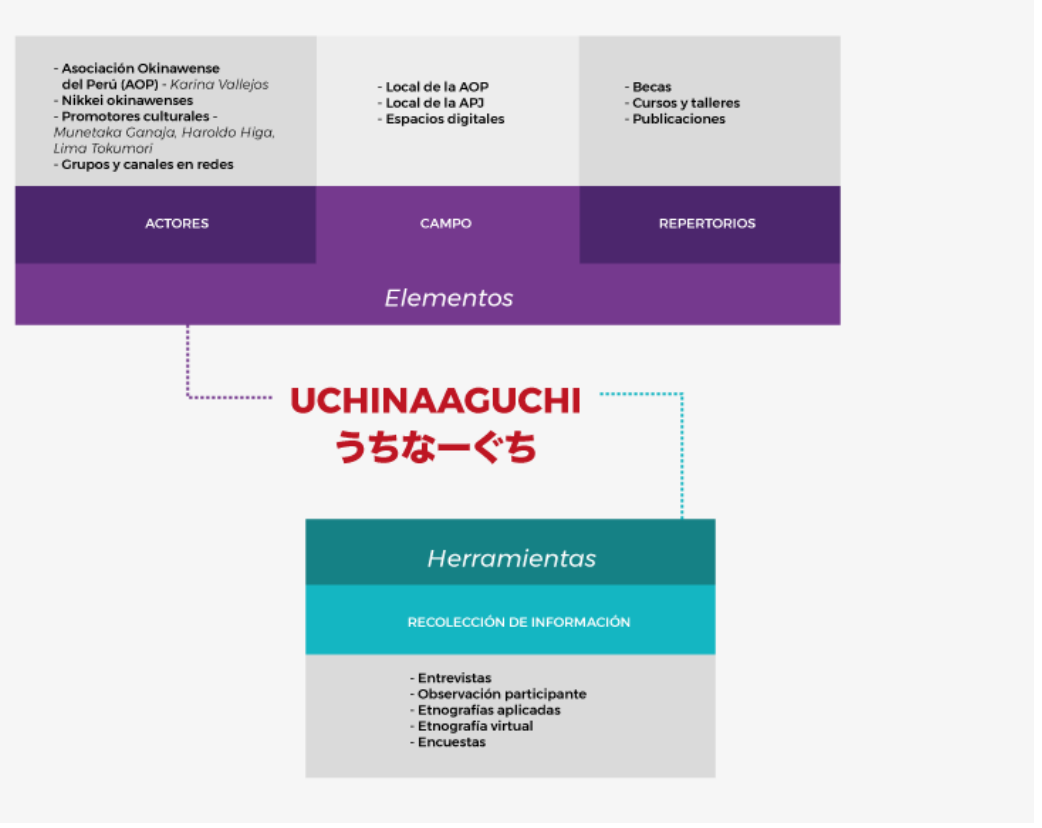

Cuadro 2. Actores, campo, repertorios y herramientas alrededor del uchinaaguchi en el Perú

\section{- Asociación Okinawense del Perú (AOP)}

Su local está ubicado en el distrito de Ate y cuenta con un complejo multiusos de gran extensión donde se realizan diferentes actividades a lo largo del año. En este espacio se difunde la cultura, la música, la gastronomía, la danza y tradiciones okinawenses. 
Repertorios: Aquí se dictan cursos y talleres de temas relacionados a Okinawa, como eisa, sanshin, comida, koto, taiko, bingata, etc. El año pasado se dictó un curso de uchinaaguchi. Además, organiza actividades culturales como el Icharibachoode, el Uchiná engeikai, el Okinawa Matsuri, etc., donde las diferentes agrupaciones participan mostrando su arte. Por último, es una de las instituciones que otorga becas a jóvenes.

\section{- Nikkeis okinawenses}

La mayoría se caracteriza por no participar activamente de las actividades organizadas por la AOP. No suelen usar el idioma uchinaaguchi porque no hay un interés de por medio. Se les encuentra en sus casas, lugares de estudio o trabajo y probablemente en la AELU (Asociación Estadio La Unión). Las costumbres se conservan gracias a sus familias, pero no se explica el significado de las tradiciones. La falta de los issei (migrantes), hace que las costumbres vayan debilitándose en cada generación que pasa.

\section{- Becarios}

Las becas son otorgadas tanto por la AOP (programas de un año) como por las instituciones Shi, Cho, Son (programas entre 3 a 6 meses, aproximadamente). En ambos casos se suelen agrupar en el local de la AOP o de la Asociación Peruano Japonesa (APJ), en Jesús María.

\section{- Promotores}

Las escuelas de cultura okinawense solicitan espacios para poder realizar ensayos tanto en el local de la AOP como de la APJ.

Repertorios: Las clases y talleres que realizan de danza tradicional, eisa, música, karate, entre otros.

\section{- Espacios digitales}


Podemos hallar algunos espacios digitales que permiten a los internautas intercambiar información sobre este idioma. Estos se encuentran tanto en Facebook como en YouTube.

Repertorios: Publicaciones que realizan en los espacios digitales (como en los fanpages o canales de Youtube de Let's sing uchinaaguchi, Okinawando, wadoku2008, etc.).

\section{- Instituciones nikkei}

La más representativa es la Asociación Peruano Japonesa, ente que se encarga de velar por la transmisión de la cultura japonesa y nikkei, mediante cursos, actividades, talleres, conferencias, intercambios, etc.

Además podemos encontrar colegios nikkei. Son seis: CEGECOOP La Unión, CEINE Santa Beatriz, CEP Peruano Japonés La Victoria, CEP Peruano Japonés Hideyo Noguchi, Colegio Inka Gakuen y la Institución Educativa Particular José Galvez. En ellos, los alumnos reciben una formación con los valores nikkei, teniendo distintas actividades culturales niponas, así como en algunos casos la enseñanza del idioma japonés, pero no se enseña en ninguna uchinaaguchi. No existe en este momento una universidad nikkei.

En el sector salud, se encuentran el Policlínico Peruano Japonés y la Clínica Centenario Peruano Japonesa. A nivel de entretenimiento y arte, está el Teatro Peruano Japonés, donde se realizan muchas presentaciones profesionales, tanto a nivel de la comunidad nikkei como externas. Por último está la AELU (Asociación Estadio La Unión), que es un centro deportivo ubicado en Pueblo Libre.

\section{c. Método}


Esta investigación tienes dos vertientes. Por un lado, se encuentra la pérdida del idioma uchinaaguchi, y por otro, la validación de un método efectivo para transmitir la data utilizando el diseño de información en un documental.

La primera parte tiene un alcance exploratorio ya que se examina un tema poco estudiado como lo es la lengua uchinaaguchi. Asimismo es descriptiva pues muestra las características y consecuencias de los idiomas en peligro de extinción. La metodología a emplearse será mixta. Por un lado, se utilizarán herramientas de índole cualitativo, como entrevistas, observación y etnografía. Por otra parte, se empleará la encuesta para poder obtener información de orden cuantitativo.

Las entrevistas se realizarán a personas conocedoras del tema como son Jorge Igei Ikehara, Director del Museo de Inmigración Japonesa al Perú; Karina Vallejos, Directora de Cultura de la Asociación Okinawense del Perú; y personas que viven en Lima que conocen acerca del idioma y su relación con los jóvenes.

La observación y la etnografía se realizarán a nivel local. Se asistirá a eventos donde se difunda la cultura okinawense en el Perú, como el Icharibachoode, Uchiná engeikai, etc. Allí se podrá ver cuánto de este idioma es utilizado entre los descendientes como vocabulario en común.

La encuesta se realizará a un grupo de 30 jóvenes que han participado de las becas otorgadas para conocer Okinawa entre 15 y 35 años aproximadamente. El objetivo es conocer principalmente su relación con el uchinaaguchi, así como con la prefectura de Okinawa. Se desarrollará vía online según los contactos en redes sociales que se puedan obtener.

Luego de obtener toda esa información, empezamos con la segunda vertiente del trabajo, relacionada a la manera más óptima, a través del diseño, de presentar esta data al público objetivo para poder generar un impacto. Primero comenzamos 
con investigación de gabinete buscando sobre metodología del diseño, diseño de información y otros temas relacionados. Con eso, se empezó a clasificar el contenido encontrado, para luego diseñarlo y validarlo con expertos como Alfredo Oshiro, Alicia Alvarez y Victor Sanjinez. El detalle de la metodología sobre el diseño se profundizará en el capítulo III. 


\section{Capítulo I}

\subsection{Marco Teórico}

\section{A. Lengua materna}

La comprensión del mundo está directamente relacionado con la lengua que uno aprende de niño. Cómo describes los colores, las texturas, las formas, los olores; qué palabras utilizas para explicar un suceso o nombrar un objeto dependen del idioma que emplees. "Es a través del idioma que utilizan nuestros allegados que aprendemos a valorar, a decidir qué es bonito, feo, deseable, prohibido, rechazable, etc." (Galdames, Walqui \& Gustafson, 2006, p.17). Como dice Calderón (2014), “el vocabulario no sólo es un medio de intercambio de ideas, pensamientos e inquietudes, sino que es el instrumento que utilizan las personas para interpretar el medio en que se desenvuelven" (p.3).

Hay palabras cuyo significado se comparte en varios idiomas, pero hay otras que no se puede utilizar una sola palabra para traducir lo que significa: "El conocimiento es capturado o codificado en palabras específicas y por tanto no se pueden intercambiar entre lenguas" (United Nations Economic and Social Council, 2018). Por ejemplo, en uchinaaguchi, existe el término "icharibachoode", pero en español solo se podría entender como "una vez que nos conocemos, somos hermanos". La riqueza conceptual se vincula con la importancia que tiene para la vida cotidiana, pues en este caso, se reconoce a los okinawenses como muy acogedores y hospitalarios. Este término resulta ser una forma de describir la realidad que se comparte entre los que lo utilizan. Ante esta situación es importante rescatar lo que sostiene Wotjak (2006): "Si solo nos manejáramos con una lengua, que forzosamente sería la materna, posiblemente no nos percataríamos siquiera de que existen otras visiones igualmente legítimas, 
convencionalizadas e institucionalizadas en otras comunidades lingüísticas y culturales" (p.13).

En ese sentido, hablar de la lengua materna, es comprender la profundidad de un idioma que configurará la comprensión y cosmovisión del mundo: "El niño al hacerse miembro de su familia y luego de su comunidad, adquiere sus conocimientos, costumbres y valores, al hacerlo construye una estructura mental que se delega de generación en generación" (Calderón, 2014, p.15).

\section{B. Los idiomas}

No se sabe con certeza el motivo por el cual el ser humano comenzó a hablar, a usar palabras para definir cosas o describir situaciones, ni tampoco cuáles fueron las que se utilizaron en un primer momento. La ciencia no puede asegurar esos detalles. No obstante, Martínez (1820) argumenta que "la invención de las lenguas no fue una producción meditada con inteligencia: ellas nacieron poco a poco e insensiblemente, según lo exigían las circunstancias, la casualidad, el temperamento, el uso y la necesidad" (p.2). Se calcula el inicio en el uso del habla entre los 100000 y 40000 años a.C. (IGER, 2016).

Asimismo, existen hipótesis que explican el inicio de las lenguas. Por un lado, se encuentra la monogénesis lingüística (Trombetti, 1905), que afirma que existió una lengua en común con todos los seres humanos y que luego por diversos motivos la lengua fue mutando hasta dividirse en una gran diversidad.

Por su parte, la poligénesis lingüística establece que en el momento de la aparición del habla, los seres humanos se encontraban en lugares diversos, ocasionando que cada comunidad cree su propio idioma o sistema de comunicación (IGER, 2016). Sea cual sea el inicio de las lenguas, en la actualidad se utilizan 7111 alrededor del mundo. 


\section{a. Definición}

La lengua es el modo en que los seres humanos nos comunicamos entre nosotros, y nos diferencia del "lenguaje animal", como diría Bernárdez (1999). Todos los idiomas que existen tienen algún tipo de parecido y es por ello que se puede traducir palabras de uno a otro, pero no a un idioma animal. Esta similitud no está relacionado a que sea parte de la genética humana, sino que se puede entender desde el funcionamiento del cerebro y sus procesos cognitivos (Bernárdez, 1999).

\section{b. Importancia}

Los idiomas son fundamentales no solo para la comunicación con las personas, sino también para la comprensión del mundo. "Las personas no solo integran en los idiomas su historia, tradiciones, memoria, conocimiento tradicional, modos únicos de pensamiento, significado y expresión, sino que, lo que es más importante, también construyen su futuro a través de ellos” (ECOSOC, 2018).

Involucran la vida cotidiana de tal forma que abarcan todos los aspectos sociales. Serrano (1999) sostiene que "tal vez lo más característico de la vida humana sea la omnipresencia del lenguaje. El universo lingüístico nos envuelve de tal forma que no podemos salir de los límites que nos impone” (p.11). La utilización del idioma permite organizar las sociedades, establecer leyes, patrones de conducta, homogeneizar los sistemas educativos, permitir la transmisión de mensajes en los medios de comunicación, profundizar en conocimiento científico, expresarse artísticamente, etc.

Además, la Declaración Universal de los derechos humanos defiende la libertad de pensamiento, de opinión y expresión, así como de acceso a la 
educación y a la información. Estos derechos deben partir de la libertad de la persona a utilizar la lengua que ha escogido para ser su herramienta de comunicación con el mundo. En muchos casos esto se ve interrumpido por la marginación y exclusión por parte de fuerzas externas a las comunidades indígenas (ECOSOC, 2018).

\section{c. Clasificación según su uso}

El presente estudio no pretende profundizar en un análisis lingüístico exhaustivo, mas busca clasificar la situación de los idiomas que se encuentran con vida. Eberhard, Simons, y Fennig (2019) organizan a las lenguas en tres grupos: institucionales $(8.06 \%)$, estables $(51.23 \%)$ y en peligro (40.71\%). Las primeras son las que han sido oficializadas por el gobierno de un país, los sistemas educativos y los medios de comunicación. Este grupo tiene menos opciones de desaparecer pues su uso es generalizado.

Las lenguas estables son las que los niños aún siguen utilizando y aprendiendo en su vida cotidiana. Sin embargo, la situación podría revertirse y en un futuro entrar en el grupo que peligra.

Por último, se encuentran las que están en riesgo de desaparecer. Éstas han sido reemplazadas por idiomas dominantes y se han dejado de enseñar a las nuevas generaciones.

En la clasificación de idiomas institucionalizados, se consideran 573 lenguas. Algunos idiomas a lo largo de la historia han tenido sus momentos de expansión y otros de reducción de uso. "No se pueden hacer previsiones por lo que respecta a la fortuna de las lenguas. Sus destinos son cambiantes e imprevisibles" (Beccaria, 2016). Podemos pensar en el inglés, que en el siglo XVI no era una lengua tan difundida como en la actualidad, hoy cuenta con 350 
millones que lo hablan como lengua materna, 60 países lo tienen como lengua oficial, y alrededor de mil quinientos millones lo tienen como segunda lengua (Beccaria, 2016). Así ha sucedido en diferentes contextos, encontrando motivaciones económicas, de colonización, de difusión cultural o de aumento poblacional, entre otros, que han permitido la expansión y uso extendido.

A la hora de pensar en los idiomas más usados se puede enfocar desde el número de hablantes nativos y desde los usuarios incluyendo los no nativos. En la primera perspectiva encontramos el chino mandarín (917 000000 de hablantes), el español (460 000 000), el inglés (379 000 000) y el hindi (341 000 000) como las lenguas maternas más habladas (Eberhard, Simons, \& Fennig, 2019).

Por otro lado, entre los idiomas más hablados en general, podemos encontrar el inglés (1 132000 000), el chino mandarín (1 117000 000), el hindi (615 000 000) y el español (534 000 000). En ambas listas se encuentran los mismo idiomas, solo que en otro orden. Sin embargo, entre el chino mandarín y el inglés existe una gran diferencia, y es que el primero se encuentra concentrado en una zona del planeta (se habla en 29 países), mientras que el inglés se utiliza en diversas latitudes, siendo hablada en unos 140 países, especialmente en África.

Según lo descrito por Eberhard, Simons, y Fennig (2019), el grupo de idiomas estables está conformado por 3643 lenguas, que incluyen las que se encuentran en desarrollo (1519) y las que están vigorosas (2124). Charles Ferguson (1968) define el desarrollo del lenguaje relacionado principalmente a la realización de tres acciones concretas planificadas: desarrollar un sistema de escritura (grafización), desarrollar normas que anulen los dialectos regionales (estandarización) y el desarrollo de terminología que permita expandir las funciones de una lengua (modernización). 
Es importante la planificación para poder entrar en la dinámica del desarrollo del lenguaje de modo que las comunidades puedan "utilizar efectivamente esas lenguas para alcanzar sus objetivos sociales, culturales, políticos, económicos y espirituales” (Eberhard et al., 2019).

Cuando los usuarios de una lengua comienzan a enseñar y a hablar una lengua dominante a sus hijos en vez de la materna, se puede decir que se encuentra en peligro. Esto quiere decir que con el paso de las generaciones, los descendientes no emplearán este idioma como natal, sino que será cuestión de tiempo que quede el último hablante, y finalmente, puede desaparecer. En muchas ocasiones han muerto los últimos usuarios de la lengua sin dejar ningún tipo de registro. "Sin una documentación adecuada, una lengua extinta no podrá revivir jamás” (UNESCO, 2003).

\section{Los Idiomas en peligro de extinción}

Actualmente existen aproximadamente 2895 lenguas en peligro de extinción (Eberhard et al., 2019). A esto hay que sumarle el creciente número de idiomas que se pierden frecuentemente. Crystal (1999a) hizo el siguiente cálculo para explicarlo:

Según las mejores estimaciones, hay unos 6,000 idiomas en el mundo en este momento. Y de estos, aproximadamente la mitad - algunos dicen más, otros dicen menos - van a desaparecer en el transcurso del próximo siglo. La deducción relevante es aleccionadora: 3.000 idiomas, en 1200 meses. Eso significa que, en promedio, hay un idioma que desaparece en algún lugar del mundo cada dos semanas más o menos.

Pero, ¿qué se entiende por la muerte de un idioma? "Una lengua muere solo cuando la última persona que lo habla muere. Un día está ahí; al día siguiente murió” 
(Crystal, 1999b). En el libro Language Death, se habla de la tragedia de la muerte de una lengua:

Cuando eres el último que lo habla, el conocimiento de tu lengua es como un repositorio, o un archivo, del pasado lingüístico hablado por tu pueblo (...) El momento en que este último hablador de una lengua que no se ha escrito o registrado muere, el archivo desaparece para siempre (Crystal, 2000).

Eberhard et al. (2019) sostienen que existen dos dimensiones en las cuales una lengua puede estar en peligro. La primera es el número de usuarios. Si las personas que reconocen esta lengua como propia son cada vez menos, así como aquellos que lo pasan de una generación a otra, podemos encontrarnos frente a una amenaza lingüística. La segunda es el uso que se le otorga a la lengua. Si ésta deja de ser usada en la vida cotidiana y no se emplea en funciones comunicativas y sociales, quedando cada vez más limitada para expresar lo que se necesita, también existe el riesgo de pérdida a mediano o largo plazo.

La UNESCO cuenta con una investigación muy detallada llamada Atlas de las lenguas del mundo en peligro (Moseley, 2010) donde se puede encontrar información valiosa sobre si una lengua es vulnerable, está en peligro, seriamente en peligro, en situación crítica o extinta. Esta herramienta permite ubicar el nombre, el grado de peligro y los países donde se habla la lengua.

Según este mapa, el Perú tiene 62 lenguas en situación de peligro o desaparecidas, de las cuales 10 se encuentran en la clasificación de vulnerables (asháninca, aguaruna, aymara, bora, quechua cuzqueño, entre otros), 18 en peligro (shipibo-conibo, hakarambeto, cachibo, ticuna, machiguenga, quechua de Ancash, de Huánuco y Ayacucho, entre otros), 14 seriamente en peligro (amahuaca, capanahua, 
quechua de Huanca, quechua de Cajamarca, entre otros), 15 en situación crítica (quechua de Chachapoyas, omagua, záparo, abishira, iquito, entre otros) y 5 extintas (cholón, culle, mochica, panobo, yameo).

En el 2002, la UNESCO convocó a un grupo de expertos sobre las lenguas en peligro con el fin de que se pueda presentar un marco para definir los grados de vitalidad y peligro de una lengua. Así, este informe permite evaluar contextos según el caso concreto, y proponer políticas gubernamentales o medidas particulares para la conservación de las lenguas y todo lo que conlleva. El documento conclusivo (UNESCO, 2003) desarrolla nueve criterios :

1. Transmisión intergeneracional de la lengua

2. Políticas y actitudes hacia la lengua por parte del gobierno y las instituciones

3. Situación de la lengua en cuanto a los ámbitos en la que se emplea

4. Disponibilidad de materiales didácticos para el uso de la lengua en la enseñanza, así como para su propia enseñanza

5. Naturaleza y calidad de la documentación disponible de la lengua

6. Posibilidades de la lengua de abrirse a nuevos ámbitos y a los medios de comunicación

7. Actitudes de los miembros hablantes de la comunidad de la lengua

8. Proporción de hablantes en la comunidad etnolingüística afectada

9. Número absoluto de hablantes

No se puede hacer la evaluación de una lengua basándose sólo en un criterio. Es necesario conjugarlos y analizar de manera conjunta para poder determinar la 
viabilidad de un idioma, su rol en medio de la sociedad y las acciones concretas que serán mejor llevar a cabo según el caso correspondiente.

Es importante destacar que cada 9 de agosto se celebra el Día Internacional de los Pueblos Indígenas del Mundo, con el fin de concientizar a manera global sobre las contribuciones e importancia de estas comunidades en el desarrollo de la paz y la construcción de un mundo más justo e inclusivo. En el marco de esta fecha, la UNESCO dedicó al 2019 como el Año Internacional de las Lenguas Indígenas (IYIL2019, por sus siglas en inglés). De esta manera reconoce la amenaza en la que se encuentran muchos idiomas y la pérdida de la herencia irreemplazable que representa la desaparición de una lengua. Con este nombramiento busca centrar la atención en diferentes ámbitos y espacios de modo que la preocupación sea masiva y efectiva (Azoulay, 2019).

\section{D. ¿Qué se pierde además de la lengua?}

No solo es la pérdida de un sistema de comunicación, sino también la pérdida de todo un ecosistema cultural. "Las lenguas, con sus complejas implicancias acerca de la identidad, diversidad cultural, espiritualidad, comunicación, integración social, educación y desarrollo, son de crucial importancia para las personas y para el planeta" (ECOSOC, 2018).

Asimismo, se expresa en proverbios, canciones, danzas, cuentos, ritos y tradiciones que nacen de la acumulación de experiencias que ha tenido la comunidad a lo largo de los tiempos. "Una gran parte de cada cultura se expresa lingüísticamente por lo que no estaría mal decir que la mayoría de los comportamientos etnoculturales serían imposibles sin su expresión a través del idioma particular con el que estos comportamientos se han asociado tradicionalmente"(Fishman, 2001). 
De este modo, “los lenguajes específicos están relacionados a culturas específicas y a sus identidades culturales en el nivel del hacer, en el nivel del conocer y en el nivel del ser" (Fishman, 2001).

\section{a. EI lenguaje y las expresiones culturales}

La lengua materna no solo permite la herencia lingüística sino que es "la herramienta para transmitir la cultura" (Calderón, 2014). Bogre Udell, cofundador de Wikitongues, sostiene que "cuando la humanidad pierde una lengua, también perdemos el potencial de una mayor diversidad en arte, música, literatura, y tradiciones orales" (Strochlic, 2018). Es por ello que es crucial tener en cuenta las pérdidas no lingüísticas que suceden tras la desaparición de una lengua. “¿Cómo puedes preservar una lengua que está en peligro de ser olvidada? Conviértela en arte" (Hartnett, 2013)

\section{- El lenguaje y la música (canciones, danzas)}

Cada lengua pertenece a una cultura y la música está relacionada con sus formas más particulares de expresar su sentir y su pensar; eso los hace únicos. "Es a través de las canciones, los bailes y las ceremonias que los pueblos indígenas mantienen sus culturas y mantienen la Ley y un sentido de identidad dentro del mundo.” (Marret \& Barwick, 2002). El riesgo que implicaría la pérdida de una de las lenguas se relaciona directamente con las expresiones musicales:

Muchas de éstas [tradiciones musicales] están ahora en peligro de perderse para siempre. Las representaciones indígenas son una de nuestras formas más ricas y hermosas de expresión artística, y sin embargo, siguen siendo desconocidas e invisibles dentro del patrimonio cultural nacional (Marret \& Barwick, 2002). 
Sin embargo, hay artistas que han encontrado en la música su forma de mantener viva su lengua, como dice Jeremy Dutcher sobre su álbum en idioma Wolastoqey: "nuestras lenguas están en nuestras canciones. Ellas nunca mueren. Tienen que irse lejos un tiempo para estar seguras. Ahora es tiempo de traerlas de vuelta" (Grier, 2018). Él mismo sostiene que “todavía tenemos hablantes de las generaciones más antiguas, así que es el momento de comprometerlos y activar la lengua para no perderla para siempre".

De igual modo, Zaraysky reconoce que "podemos comenzar a mantener vivas estas lenguas en peligro, aprendiendo las canciones en esos idiomas. Podemos grabar a personas que hablan estas lenguas; grabarlas cantando y hablando, y que alguien que sea bilingüe nos ayude a traducirlo" (TEDxTalk, 2014). Asimismo, argumenta que la música en el ámbito educativo tiene mucha eficacia y de eso se puede sacar beneficio en la enseñanza de las lenguas.

\section{- EI lenguaje y la cosmovisión}

Cada lengua encierra toda una comprensión de la realidad. Es por eso que es un deber de la humanidad de preservar y proteger las lenguas que se encuentran en peligro de extinción. Conocer una cultura es reconocer su visión del mundo y valorar los conocimientos que han sabido conservar por siglos.

La extinción de una lengua significa la pérdida irrecuperable de saberes únicos, culturales, históricos y ecológicos. Cada lengua es una expresión irremplazable de la experiencia humana del mundo. Por lo tanto, el conocimiento de una lengua cualquiera puede ser la clave para dar respuesta a cuestiones fundamentales en el futuro. Cada vez que muere una lengua tenemos menos datos para entender los patrones de estructura y función del lenguaje humano, la 
prehistoria humana y el mantenimiento de los diversos ecosistemas del mundo. (UNESCO, 2003)

Como dice Maffi (2002), "los idiomas siguen respondiendo y adaptándose a las necesidades de comunicación de sus usuarios, sirviendo como puentes dinámicos entre el pasado y el futuro y como vehículos para la transmisión continuamente innovadora de los conocimientos, creencias de una comunidad, valores y prácticas".

\section{E. Uchinaaguchi}

\section{a. Introducción}

Antiguamente existía el Reino de Ryukyu, en lo que hoy se conoce como el archipiélago de Okinawa. La UNESCO reconoce 6 idiomas que se agrupan en lo que se conocen como lenguas ryukyuanas. Cinco de éstas (las lenguas de Kunigami, Uchina, Miyako, Yaeyama y Dunan) son habladas en la prefectura de Okinawa, mientras que Amami se utiliza en la prefectura de Kagoshima (Heinrich \& Ishihara, 2017). En este caso, centraremos el estudio en el Uchina o Uchinaaguchi.

\section{b. Historia}

El uchinaguchi tiene muchos dialectos y subdialectos según la región donde uno se encuentre. El de Shuri, o de Naha, fue el que se estandarizó cuando estuvo como rey Sho-Shin (1477-1526). Esta variación fue la que se empleó en la clase aristocrática y fue en la que se escribieron la mayor parte de poemas y canciones de Okinawa.

Durante el período Meiji (1868-1912), se buscó que el idioma japonés fuese impuesto en todo el país, por lo que se establecieron políticas lingüísticas y colonizadoras para establecerlo. Según la ideología política del momento, las lenguas que no eran el idioma nacional, eran degradadas a un dialecto. Fue así que en las escuelas públicas se prohibió la enseñanza y la utilización de otras lenguas que no 
fueran el japonés en 1907, con la Ordenanza de la regulación de dialectos (Heinrich, Bairon, \& Brenzinger, 2009).

Por varios años, tanto los okinawenses como los pobladores de Tohoku y Kyushu, zonas donde se utilizaban lenguas distintas al idioma nacional y geográficamente distantes a la capital, sufrieron discriminación y castigo. En los colegios de Okinawa, los alumnos que empleaban estas lenguas, eran obligados a utilizar un cartel colgado del cuello llamado hogen fuda, donde decía literalmente su traducción, "etiqueta de dialecto". Cada vez que un alumno empleaba una palabra en uchinaguchi, se lo tenía que colocar hasta que otro diga alguna. Al final del día, el que la llevaba recibía un castigo de parte del profesor (Goebel \& Fotos, 2001).

En la década de 1950, algunas comunidades grandes locales decidieron no transmitir los idiomas ryukyuanos a sus siguientes generaciones, causando así que hayan menos hablantes y menos lugares donde se utilicen. Perdiendo presencia en los hogares, estas lenguas se introducen en la fase final de extinción. (Heinrich et al., 2009). La Asociación Okinawense de Profesores tuvo una actitud negativa hacia las lenguas ryukyuanas durante el período de ocupación americana (1945-1972) (Ishihara, Miyahira, van der Lubbe, \& Heinrich, 2019).

Luego de la Segunda Guerra Mundial, se produjo la ocupación americana hasta que en 1972, Okinawa fue oficialmente devuelta a Japón. Sin embargo, se produjeron cambios que hicieron sentir como si hubiera existido una ocupación japonesa (cultural, lingüística, económica, políticas, etc.) pues las medidas gubernamentales consideraban al uchinaguchi como un dialecto, un idioma de segunda clase.

\section{c. Actualidad}

Según el Atlas de las lenguas del mundo en peligro (UNESCO, 2010), el uchinaguchi es utilizado por unas 400000 personas en la actualidad y es considerado 
dentro de una de las 8 lenguas que se registran. Como ya se mencionó, se encuentra en un proceso donde la transmisión intergeneracional se ha visto estancada.

Como enfatizan Heinrich e Ishihara (2017), "los nacidos antes de 1950 son bilingües japoneses y de ryukyuano, los nacidos entre 1950 y 1980 son hablantes oxidados o bilingües pasivos de ryukyuano, y los nacidos después son monolingües japoneses y hablantes simbólicos de ryukyuano".

Observamos que las nuevas generaciones se encuentran cada vez menos relacionadas e interesadas en la lengua. Según una encuesta realizada por el diario Ryukyu Shimpo de Okinawa, el 90\% de las personas entre 20 y 40 no pueden hablar ni entender el uchinaguchi y una encuesta dirigida por el profesor Masahide Ishihara de la Universidad de Ryukyu, indica que solo el 5\% de los menores a 30 años pueden hablar fluidamente el uchinaguchi (Mie, 2012).

Sin embargo, por el valor cultural, histórico y turístico que actualmente está teniendo Okinawa tanto a nivel nacional como internacional, el sentido de identidad está variando, sobretodo entre los jóvenes. Esto ha ocasionado que surjan alternativas modernas sin perder la conexión con lo antiguo.

Uchina-Yamatoguchi es una mezcla entre japonés y uchinaguchi, y ha surgido como una alternativa utilizada entre los jóvenes. Según el análisis de Ota, esta nueva lengua debería ser considerada incluso "una creación lingüística emergente y auténtica de Okinawa" (Hein \& Selden, 2003).

\section{d. Problemática}

Una de las dificultades principales para solucionar la crisis del uchinaguchi es que dentro de Okinawa existen muchas variantes del idioma y que incluso "lingüistas y oficiales de gobierno no pueden determinar cuál es el dialecto en que debería codificarse como forma estandar” (Mie, 2012). Una vez que se decida cuál será el 
dialecto elegido, se podrá comenzar a unificar a nivel educativo con libros escolares e iniciativas más concretas.

Asimismo, algunos consideran que las lenguas ryukyuanas no son realmente japonesas, por lo que en vez de unificar al país, lo que se haría es fragmentarlo (Heinrich \& Ishihara, 2017). Es contra este problema que se ha tenido que lidiar durante bastante tiempo: ser japonés contra promocionar algo que no es japonés.

Podemos encontrar, en ese sentido, dos momentos importantes: el primero es cuando las lenguas del Ryukyu fueron impedimento para la unificación del país por medio del monolingüismo. La segunda es cuando la Prefectura de Okinawa comenzó a tener una actitud favorable hacia las lenguas locales (Ishihara et al., 2019).

Sin embargo, "si las comunidades de hablantes y los lingüistas no actúan inmediatamente, todas las lenguas ryukyuanas habrán desaparecido para el 2050” (Heinrich et al., 2009).

\section{e. Iniciativas}

Según una encuesta realizada por la Prefectura de Okinawa en el 2014 (Heinrich \& Ishihara, 2017), el 70\% querían que se enseñe la lengua local en las escuelas. Aunque la realidad sea muy distinta, puesto que la currícula la elige el gobierno central de Japón, es importante conocer el pensar y sentir de los pobladores con respecto al tema. No obstante, en 1989 hubo un cambio en el sistema educativo, permitiéndose enseñar no solo el japonés sino algunas lenguas locales, así como la introducción de la hora de estudio integrada en el 2002, que permitía cursos de lenguas ryukyuanas, cultura, historia y artes escénicas (Heinrich \& Ishihara, 2017). Lo difícil de aplicar, en este caso uchinaguchi en las escuelas, es que la mayoría de los profesores de colegio no hablan esta lengua y no existen acreditaciones para profesores de lenguas ryukyuanas. 
Si bien es cierto aún falta mucho para alcanzar la revitalización de la lengua, se pueden encontrar proyectos que permiten tener esperanza en los cambios con respecto al uchinaguchi.

La instauración del Día de la lengua comunitaria (shimakutuba no hi) en 2004 fue uno de los más representativos, obteniendo a su vez apoyo de la prefectura desde el 2006 (Heinrich et al., 2009).

Asimismo, podemos encontrar algunas iniciativas gubernamentales como el Concurso de Oratoria en Lengua Nativa a lo largo de toda la prefectura, que se inició en 1996; el proyecto Plan Maestro de Visión del Siglo XXI de Okinawa, que incluye el tema de las lenguas locales; la Campaña Prefectural de Lengua Local, que investigó con diferentes grupos cómo poder promocionar mejor la utilización de estas lenguas; el Departamento de Cultura, Turismo y Deporte publicó un calendario donde cada día tiene un proverbio en uchinaguchi y un manual de lenguaje llamado Hablemos en la lengua comunitaria, etc.

\section{F. Uchinaaguchi en Perú}

\section{a. Historia}

Como comentó Jorge Igei, Director del Museo de Inmigración japonesa al Perú (ver Anexo 1), los primeros migrantes japoneses llegaron hace 120 años. El primer grupo de migrantes okinawenses estaba conformado por 36 personas y llegó en el año 1906 en el buque "Itsukushima Maru". Ellos estaban destinados a laborar en las haciendas azucareras del norte del país, especialmente en La Libertad (comunicación personal, 18 de octubre de 2019).

Durante la Segunda Guerra Mundial, Perú se alió con EEUU convirtiéndose enemigo de Japón. Es por ello que se prohibió el uso del japonés, se clausuraron 
algunos locales y escuelas, así como reuniones. Esto también produjo que el uchinaaguchi deje de utilizarse.

Inicialmente los japoneses habían venido al Perú con la intención de volver a su país, pero luego del conflicto bélico, el país nipón se encontraba devastado. Es por ello que estos migrantes decidieron continuar su futuro aquí, dejando de usar la lengua materna para aprender el español y adaptarse a la sociedad peruana (J. Igei, comunicación personal, 18 de octubre de 2019).

\section{b. Actualidad}

Los únicos que hablan este idioma en el Perú son los nisei que lograron aprenderlo mientras escuchaban a sus padres hablarlo. Sin embargo, no lo utilizan para hablar porque es un poco difícil de pronunciar (J. Igei, comunicación personal, 18 de octubre de 2019). Ellos bordean los 80 años y vivieron su niñez durante la Segunda Guerra Mundial. Las generaciones más jóvenes no conocen ni se interesan mucho en aprender y menos en utilizarlo.

\section{c. Problemática}

En un estudio realizado en la comunidad nikkei peruana por Lily Niland (2012), se puede observar cómo el uchinaguchi no es considerado como lengua materna, salvo para 6 de los 200 participantes.

Asimismo, gracias a la encuesta pudimos observar que el grado de interés o identificacón con el idioma no está directamente relacionado con el tiempo visitado o con la generación a la que pertenece. Hay casos en los que alguien que ha vivido una beca kenpi (un año) tiene un grado de identificación de 3 (en la escala del uno al cinco, donde cinco es sentirse más okinawense), mientras que alguien que ha experimentado la beca de una semana, tiene grado de identificación de 5. Es importante rescatar que ninguno ha marcado que no se siente okinawense. Junto con eso nos damos cuenta que 
tampoco hay relación con la generación en la que pertenece. Algunos niseis marcan cuatro, los sanseis marcan cinco o tres, y hay algunos yonseis que marcan cinco.

También observamos que no hay relación en cuantas palabras hay uchinaaguchi. El que más frases conoce es un yonsei.

Asimismo, en la encuesta realizada en este estudio, los jóvenes respondieron que es un idioma que no les resulta práctico ni beneficioso, pues buscan aprender idiomas que les resulten atractivos para su futuro (laboral, académico o cultural). Además, mencionan que no hay lugares donde aprender ni tampoco mucha utilidad de uso aquí (ver Anexo 2)

En relación al uso de palabras en uchinaaguchi, la mayoría de los encuestados sostienen que saben menos de $10(52,7 \%)$ y solo uno sostiene que sabe de 41 palabras a más. Podríamos concluir de esto que si la situación entre los jóvenes más conectados con Okinawa es que en su mayoría saben 10 palabras, lo más probable es que la mayoría de los nikkeis okinawenses que no han sido becarios, no sepan ni una sola palabra. Es decir, que esta lengua, para la siguiente generación en Perú, estará extinta por falta de transmisión intergeneracional.

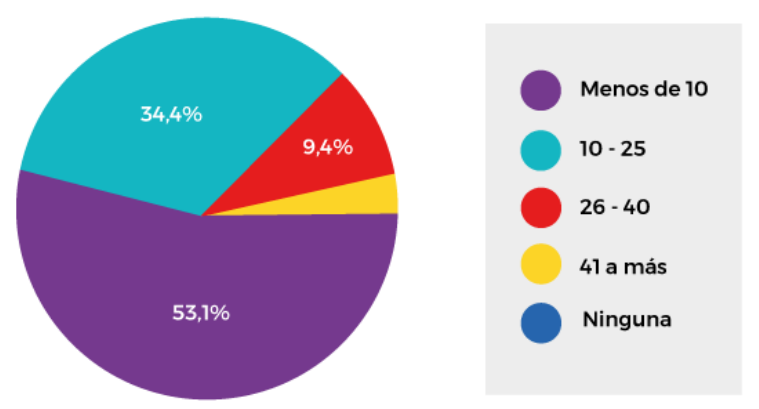

Figura 1. ¿Cuántas palabras o frases conoces en Uchinaaguchi?

En cuanto a dónde aprendieron, lo poco que conocen del idioma, el 71,9\% comenta que lo conoce gracias a la beca en la que estuvo. Es importante decir que hay un porcentaje considerable $(56,3 \%)$ que aprendió en su hogar. 


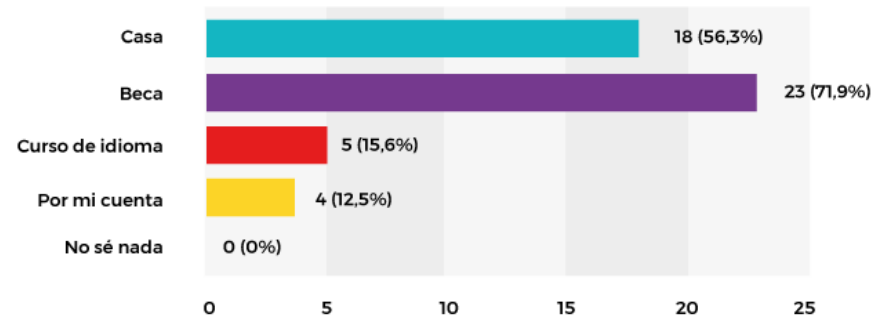

Figura 2. Lo que sabes de uchinaaguchi, ¿dónde lo aprendiste?

En cuanto a la pregunta de si han escuchado a alguien hablar uchinaaguchi en casa, el 41,9\% contestó que a sus abuelo, mientras que el 32,3\% dijo que no escuchó a nadie emplearlo en casa.
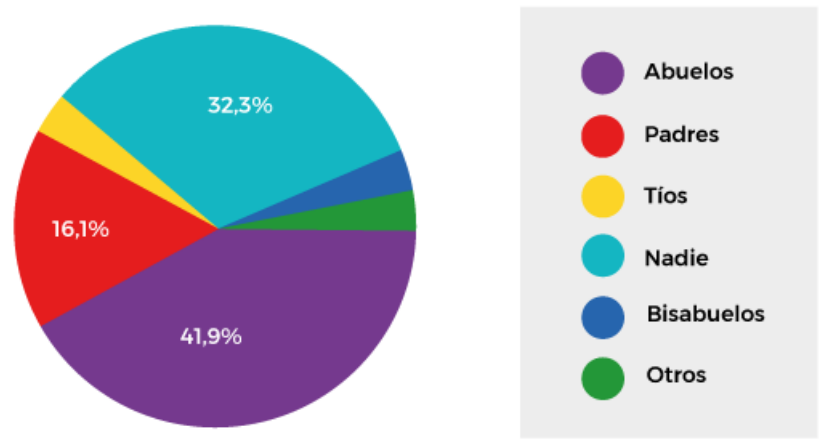

Figura 3. ¿Escuchaste a alguien hablar uchinaaguchi en tu casa?

Esta lengua, que en su mayoría es del abuelo, los encuestados lo sienten como una lengua no hablada. El 40,6\% considera que se encuentra seriamente en peligro y el 21,9\% en una situación crítica; es decir, que los entrevistados sienten que como no se habla en su entorno, esta lengua no existe. 


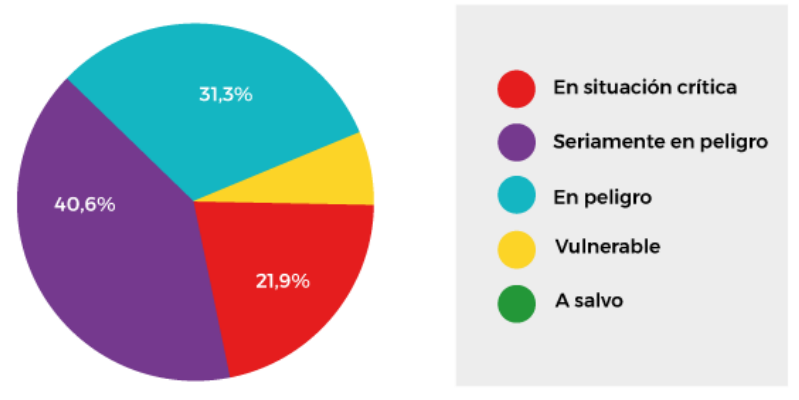

Figura 4. ¿En qué situación piensas que podría estar, según la clasificación de la UNESCO para las lenguas en peligro de extinción?

Sabieno la realidad de la lengua, el $62 \%$ de los encuestados responde que les gustaría aprender el idioma. Sólo uno responde que no.

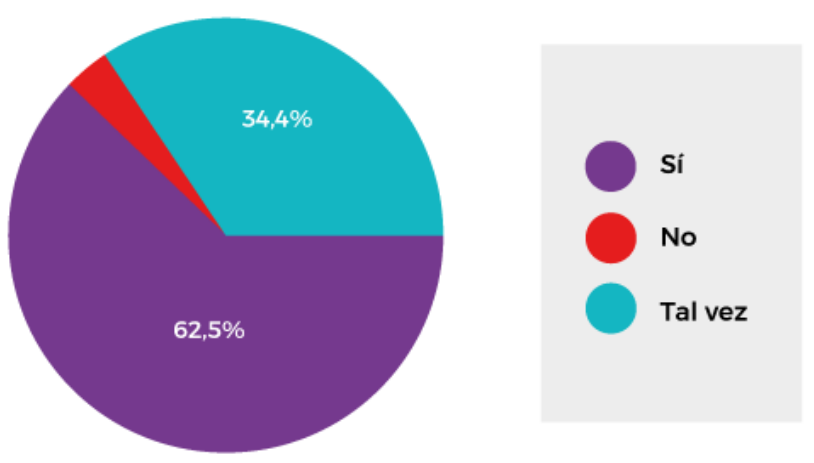

Figura 5. Si supieras que se encuentra en peligro de desaparecer en algunos años, ¿te gustaría poder aprender algo de ella?

Lo interesante es ver que todos los ex becarios se sienten en un grado de identificación alto, ya que ninguno ha marcado el uno o el dos. Esto se convertiría en una oportunidad ventajosa para las futuras iniciativas. 


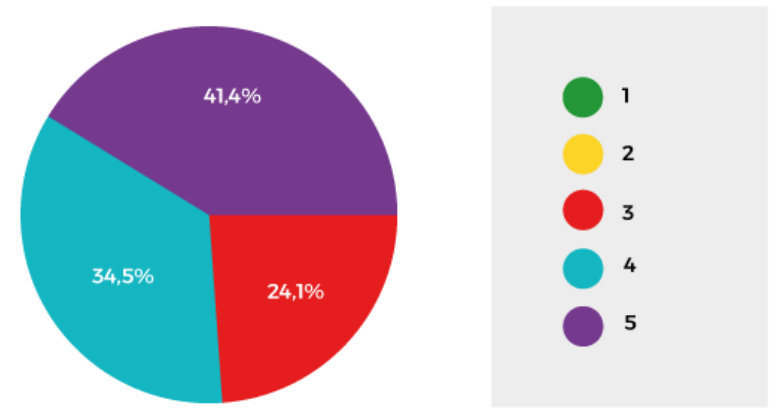

Figura 6. Actualmente, ¿cuál es tu grado de identificación con Okinawa? (1: no muy identificado / 5: muy uchinanchu)

Podemos observar en la Figura Y e Y que el 62\% tiene algún tipo de nexo para poder aprender pues conocen a alguien que ya hable la lengua, tanto en Okinawa como en Perú.

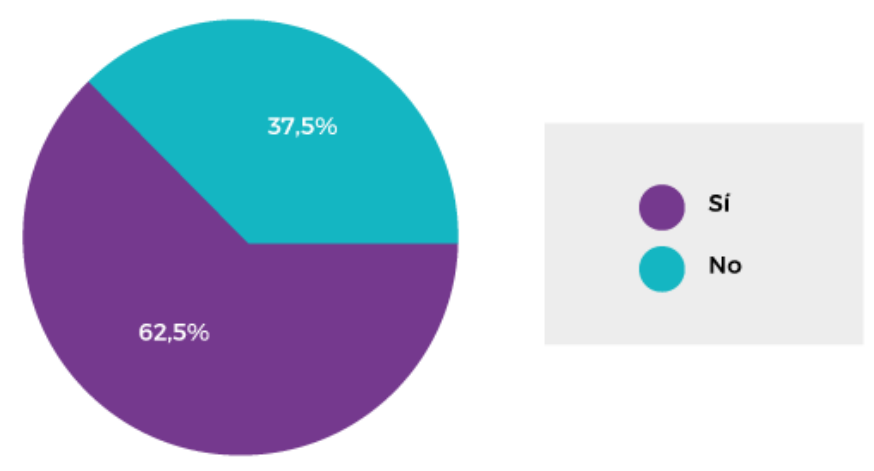

Figura 7. ¿Conoces personas que dominen este idioma en Okinawa?
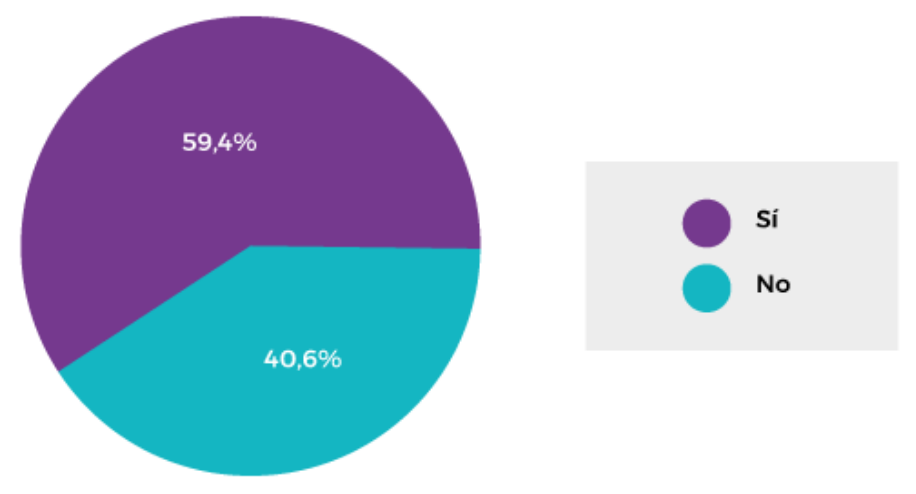
Figura 8. ¿Conoces personas que dominen este idioma en Perú?

En resumen, Podemos observar que existe un alto grado de identificación y ganas para aprender el idioma, pero que no existen las herramientas correctas ni suficientes para poder hacerlo.

\section{G. Identidad nikkei}

\section{a. Issei (migrantes japoneses)}

Son los japoneses que por diversos motivos salieron de su país en busca de nuevas y mejores oportunidades. En el Perú la migración se dio en bloque y está bastante estructurado el grupo generacional (a diferencia de otros países que siguió recibiendo migrantes japoneses durante y después de la Segunda Guerra Mundial, lo cual no sucedió aquí).

Su idioma natal es el japonés, y aquellos que vinieron de Okinawa utilizaban también el uchinaaguchi. Al estar varios años en el Perú, aprendieron el español para adaptarse a la sociedad.

\section{b. Nisei (segunda generación)}

Son los hijos de los issei que nacen fuera de la patria de sus padres. Tienen en promedio 60 años a más. Sin embargo, los menores de 80 no hablan japonés porque se cerraron los colegios nikkeis durante la segunda guerra. Los que nacieron antes de la guerra culminaban solo primaria.

Entre los nisei y los issei, hubieron diferencias que generaban ciertas distancias. El idioma fue uno de ellos, puesto que los japoneses se habían formado con un sistema educativo propio del Japón, a pesar de haber estado aquí. Los nisei, la mayoría, vivieron la época de la clandestinidad escolar y sus oportunidades no fueron las mismas. 
Después del conflicto bélico, los japoneses que habían viajado con la intención de retornar, cambiaron de parecer puesto que Japón había sido devastado y quedó destruido. Además, ya se habían acostumbrado, a pesar de las dificultades, a la vida en Perú. Esto hizo que los nisei fueran impulsados a incluirse en la sociedad peruana con mayor determinación. Esto se realizó mediante la adquisición de ciertas costumbres peruanas (como los nombres en español), bautizarse para ser incluidos en ciertos colegios y socializar más con los vecinos no japoneses, entre otros. Asimismo, tuvieron oportunidad de estudiar en universidades, destacándose en sus estudios y en el trabajo, sobretodo por los valores japoneses que habían aprendido de sus padres.

Los nisei pasaron un proceso de crisis de identidad, puesto que sus padres eran japoneses, hablaban en japonés, pero ellos debían desarrollarse en la sociedad peruana y hablaban español.

\section{c. Sansei (tercera generación)}

Son los nietos de los migrantes japoneses. La mayoría nacen en la post guerra. Muchos han conocido a sus abuelos. Sin embargo, existió una barrera del idioma con ellos pues no hablan japonés. No tuvieron mucha crisis de identidad puesto que su sentimiento de peruanidad es bastante elevado. La relación que tienen con Japón es básicamente de origen pero no es estrecha.

\section{d. Yonsei (cuarta generación)}

Son los bisnietos de los migrantes japoneses. Quizás algunos hayan logrado conocer a sus bisabuelos (los okinawenses son de las poblaciones más longevas del mundo). También se consideran muy peruanos y no suelen hablar japonés.

\section{H. Descendientes de Okinawa en Perú}


Dentro de la colectividad peruano japonesa, hay descendientes de diferentes prefecturas del Japón. En la actualidad existen aproximadamente unos 40000 peruanos de origen okinawense.

\section{a. Conexión con las raíces}

En la actualidad, en nuestro país hay diversas actividades que permiten que los nikkei okinawenses puedan conectarse con sus raíces. Sin embargo, sigue resultando complicado para algunas instituciones poder convocar a los jóvenes para que participen en estos eventos. Hay clases de Eisa, de sanshin, de Odori (baile), cocina, karate, etc. Además hay actividades culturales y artísticas en la Asociación Okinawense del Perú, donde se puede disfrutar de eventos como el Matsuri, el Icharibachoode, Uchina engeikai, etc.

\section{Diseño}

\section{a. Definición}

En un sentido más elemental, Dalley (1980) define al diseño como la “ordenación, composición y combinación de formas y figuras”. Sherin (2018) va más allá cuando conceptualiza al diseño gráfico como la práctica de combinar textos, imágenes y otros elementos para comunicar un mensaje o crear una experiencia para el usuario. Por su parte, Landa (2017) sostiene que es una disciplina profesional de las artes visuales, una forma de comunicación usada para dar un mensaje a una audiencia.

Las áreas en las que se involucra el diseño son muy variadas, “desde los más evidentes como anuncios y carteles, al diseño de mapas, sellos, camisetas o construcciones" (Delley, 1980).

Asimismo, Sherin (2018) explica que el diseño gráfico comenzó en espacios bidimensionales pero que hoy incluye además espacios 3D y virtuales como blogs, 
trípticos, plataformas de realidad virtual, empaques, revistas, posters, merchandising, aplicaciones móviles, páginas web, libros, logos, videojuegos, entre otros.

\section{b. Objetivo}

“La razón de ser del diseño gráfico es comunicar” (Reina, 2011, p.152) y por eso es importante enfocarse en cómo hacer más efectivo el mensaje que se quiere dar a conocer, sino podemos caer en lo que dice Reina: "Todo proceso de comunicación es un proceso de transmisión de información, pero no toda transmisión de información es comunicativa" (2011, p. 140).

Es fundamental que el diseño gráfico, para que cumpla con efectividad su objetivo de comunicación, tenga en cuenta conocimientos teóricos relacionados al lenguaje gráfico, así como a términos de composición. La función del diseño gráfico no es solamente estética, sino comunicativa, pues cumple un propósito de recepción eficaz de un mensaje. Vemos así que "las figuras por sí mismas se convierten en pequeñas técnicas creativas al servicio de una argumentación más llamativa e interesante y no tanto de la ornamentación puramente estética." (Gamonal-Arroyo y García-García, 2015, p.55).

Para lograr esto es necesario "ser consciente de las posibilidades del discurso retórico, conocer sus principios y fundamentos" (Gamonal-Arroyo y García-García, 2015, p.55). Podemos hablar entonces de un lenguaje visual que hay que conocer y manejar correctamente para poder amplificar las opciones que tenemos para comunicar. Esto se puede encontrar en lo que sostiene Reina (2011): "El diseñador es un estratega, que debe conocer los fundamentos simbólicos que estructuran los sistemas de comunicación visual y debe procurar la transformación del otro, yendo mucho más allá de facilitar lecturas claras, desempeños adecuados e impactos efectivos" (p. 152). Si bien es cierto el diseño cumple una función comunicacional, no 
debe descuidarse en ningún sentido la parte estética que servirá para captar la atención de quien vea su mensaje.

No obstante, hay que ver que el diseño tiene además otro tipo de alcance y es capaz de alcanzar otros objetivos. Éste puede hacer de la comunicación una herramienta de transformación, como dice Reina: “A través del diseño, y específicamente en lo relacionado con el diseño de mensajes, el diseñador debe impactar a la sociedad desde muchos frentes" (2011, p.152).

Si se evalúa la problemática de esta investigación, el diseño puede ser capaz de motivar a las personas al aprendizaje de un idioma, de unir a estos jóvenes con sus raíces, de rescatar una lengua y todo lo que viene con ella en términos culturales e históricos. De este modo, utilizar el diseño para intervenir el problema, ayudará a nivel receptivo, pues generará interés y relación: “el diseño muestra una serie de valores que buscan que el público los acepte y se adhiera a ellos. Y en eso, el impacto estético tiene una enorme importancia en la percepción del receptor" (GamonalArroyo y García-García, 2015, p.52).

Por tanto, el diseñador gráfico tiene la misión no solo de crear piezas atractivas y comunicativas, sino de "diseñar acciones expresivas que permitan la interconexión entre el usuario y el diseño a partir de la cual se constituye la comunicación dentro del contexto social generando intercambios sociales a través de su discurso" (GamonalArroyo y García-García, 2015, p. 44).

Utilizado con criterios comunicacionales y con fines sociales adecuados, el diseño es capaz de generar un impacto importante en la sociedad: "el diseño es una herramienta social poderosa" (Reina, 2011, p. 152).

\section{c. Metodología}


El diseño como disciplina académica ha tenido una vinculación con la ciencia y la investigación, buscando desligarlo de la subjetividad, “dada por sus orígenes empíricos, técnicos y artísticos” (Herrera, 2010). Ha habido una tendencia hacia los métodos más lógicos y sistemáticos del diseño que se ha evidenciado desde mediados de los 50's. (Cross, 1984).

De este modo, las metodologías que se emplearon para organizar el proceso de diseño estuvo fuertemente marcado por el método científico, como el caso del Modelo General del Proceso de Diseño (MGPD), de la Universidad Autónoma Metropolitana de México. "Dicha metodología contiene cinco fases: Caso, Problema, Hipótesis, Proyecto y Realización, que muestran claramente su herencia científica” (Herrera, 2010). Asimismo, hubo una corriente que se apoyó en las teorías psicológicas para dar sustento científico al diseño, especialmente en las teorías de la Gestalt y de la percepción (Herrera, 2010).

Ha habido distintos métodos que han buscado sistematizar el proceso de diseño. Podemos encontrar el de Christopher Jones, quien dio en Londres la primera “Conference on Design Methods" en el año 1962. Su intención fue considerar el proceso de análisis como complemento y no como reemplazo al proceso creativo (Cross, 1984). Él presenta dos conceptos clave: la caja negra y la caja transparente (Gonzalez, s.f.).

El primero consiste en que "el diseñador es capaz de producir resultados en los que confía y que a menudo tienen éxito, mas no es capaz de explicar cómo llegó a tal resultado" (Gonzalez, s.f.). Algunas características de la caja negra son que está relacionada a experiencias previas pero también a los conocimientos actuales del problema, que pueden aparecer las ideas como una "iluminación” repentina, que 
puede ser difícil entender cómo se obtuvo el resultado pues no hay un orden específico, etc.

Por otro lado, la caja transparente presenta cinco características que son problema, divergencia, transformación, convergencia y evaluación (Gonzalez, s.f.). Lo presentado por Jones permite que tanto el lado más esquemático como el subjetivo puedan vincularse y complementarse para obtener los resultados creativos esperados. Como dice González (s.f.): "Se puede decir que tanto el método de la caja negra como el de la caja transparente tienen como resultado ampliar el espacio de búsqueda de la solución al problema del diseño".

\section{J. Semiótica en el diseño gráfico}

Si bien es cierto en esta parte del informe no se busca profundizar en el complejo mundo de la semiótica, se quiere resaltar algunos aspectos básicos que se relacionan con su utilización en el diseño.

\section{a. Definición de semiótica}

El término Semiótica fue desarrollado por el filósofo Pierce, y Saussure profundizó en el concepto y propuso el de Semiología (Chao-Ming \& Tzu-Fan, 2015). Pierce define a la semiótica como "la doctrina de la naturaleza esencial y de las variedades fundamentales de cualquier clase posible de semiosis" (Pierce en Eco, 2000, p.32), entendiendo a la semiosis como una acción donde debe existir una relación de tres sujetos: signo, objeto y el interpretante. (Eco, 2000).

Por su parte, Saussure definió la semiología como "una ciencia que estudia la vida de los signos en el marco de la vida social” (Saussure en Eco, 2000, p.31). Asimismo, estableció las dos caras de los signos: el significado, “el contenido informativo que se transmite" (Marcos-Marin, 2020) y el significante, "la expresión de 
ese contenido" (Marcos-Marin, 2020), los que pueden conocerse también como mensaje y señal.

La diferencia entre la definición que plantea Saussure y la de Pierce, es que la segunda es un poco más amplia y puede adjudicársele a un emisor no humano, como la naturaleza. Sin embargo, como ambos autores analizaban el fenómeno de los signos dentro del lenguaje y el proceso comunicativo, se limita a la definición de signo a “todo lo que, a partir de una convención aceptada previamente, pueda entenderse como alguna cosa que está en lugar de otra" (Eco, 2000). No obstante, los términos suelen utilizarse en ocasiones como si fueran sinónimos: “a veces se utiliza el término Semiótica como equivalente de Semiología” (Marcos-Marin, 2020).

En cuanto a los signos, Pierce los entiende como los significantes y establece tres clases de ellos para la comunicación humana: símbolo, ícono e índice. Los símbolos se pueden definir por ser signos arbitrarios, "que se definen por el carácter convencional de la relación entre la expresión y el contenido" (Marcos-Marin, 2020, p.66). En ese sentido, los signos lingüísticos son símbolos, pues la lengua ha sido creada de forma convencional para designar significados según las necesidades de comunicarse. Por ello, para el símbolo es importante destacar el papel del intérprete, quien debe decodificar los signos para comprender el mensaje.

Los iconos "son signos motivados, que no necesitan que el objeto cuyo significado comunican tenga existencia real" (Marcos-Marin, 2020, p.67). No necesita de un intérprete, ya que puede existir por sí mismo.

Por último, el indicio, al igual que los íconos no requieren de un intérprete para tener sentido, pero su diferencia radica en que "son dependientes de la situación del objeto al que se refieren: si el objeto cambia de lugar, el indicio cambia." (Marcos- 
Marin, 2020, p.67). Si bien es cierto, de los tres tipos de signo es el más complejo de entender, Marcos-Marin (2020) lo explica así:

Para poder decir de un signo que es un indicio, se requiere que haya una conexión conocida entre un signo A y su significado o contenido $\mathrm{C}$, de manera que de que exista A se desprenda que existe $\mathrm{C}$, pero por medio de una relación de indicación (p. 68).

El ejemplo que expone es que si hay un crimen por apuñalamiento en una casa, se detienen a todos los que estuvieron ahí y uno de ellos tiene manchas de sangre encima, la policía puede decir que la sangre es un indicio de que es el asesino. Sin embargo, si el que tiene la sangre fuese un cocinero que acaba de matar un pollo, ese signo ya no sería el indicio de que es el asesino. La conexión se rompe (Marcos-Marin, 2020, p.68).

\section{b. Semiótica y diseño gráfico}

En sus orígenes, la semiótica fue planteada por Saussure como un análisis enfocado estrictamente en la lingüística, y los signos utilizados dentro del lenguaje. Estas teorías no fueron ampliadas en la utilización general de los signos, por lo que era difícil encontrarle relación sencilla para ser aplicada en el diseño gráfico.

En ese sentido, Pratt (s.f.) sostiene que para los comunicadores visuales, las teorías de Saussure tienen dos problemas. El primero, está basado en uno de los principios que dice que no hay ideas en la mente antes que el lenguaje las coloque ahí. En ese sentido, las ideas son construcciones culturales y subjetivas. Esto implicaría que para una comprensión correcta de un mensaje, el receptor debe compartir un entorno cultural con el emisor.

Lo segundo a considerar es que Saussure sostiene una estructura sencilla del signo, definiendo el significante y el significado. Al partir del lenguaje, no establece 
más allá de las relaciones que pueden haber entre las letras y el concepto detrás, pero no toma en cuenta la tipografía y lo que pueda suscitar expresarlo de un modo u otro. De este modo, el enfoque centrado en lo lingüístico no permite que se consideren cómo las imágenes, los colores, texturas y tipografías puedan interactuar y comunicar cierto tipo de mensajes (Pratt, s.f.).

Por otro lado, las teorías de Pierce, al tener la clasificación de los signos desarrollada líneas arriba, permite que los diseñadores puedan analizar de un modo más profundo y complejo la realidad. Esto permite que a la hora de realizar una pieza pueda abrir más posibilidades al tener en cuenta las categorías de símbolo, ícono e índice (Pratt, s.f.).

\section{c. Elementos del diseño}

\section{- Imagen y texto}

Podemos entender el diseño gráfico como la distribución de textos e imágenes en un espacio, con un sentido para cumplir un propósito. Es por ello que el texto y la imagen son elementos fundamentales en la composición de cualquier pieza gráfica.

Como describe Costa, "los signos alfabéticos son unidades gráficas elementales de los sonidos del habla" (2007, p. 123). Para Lupton y Phillips, "las letras son también formas abstractas hechas de líneas y curvas. No tienen sentido alguno fuera de los sistemas de escritura.” (2016, p.100). Es por ello que es importante tener en cuenta que las letras deben ser entendidas mediante un código o un lenguaje.

Es importante considerar lo que dice Costa: "el mensaje escrito es con demasiada frecuencia considerado por el diseñador como secundario, cuando no 
inevitable" (2007, p. 27). Hay que tener en cuenta que el uso de los textos y las imágenes es distinto, y que "en el mundo actual predominan las imágenes en todos los ámbitos del aprendizaje de comunicación y de información” (Ministerio de Educación, 2012, p. 114). Las imágenes permiten que los receptores visuales tengan mayores oportunidades de ser atraídos $y$, dependiendo de la composición, pueden tener grandes resultados de recordación.

De esta manera "la alfabetización visual ya no se asocia sólo a la lectura y escritura de textos, también a las 'nuevas alfabetizaciones' que aportan otros lenguajes y posibilidades" (Ministerio de Educación, 2012, p. 98). Pero no es cuestión de cuál es más usado sino cómo poder llegar a la complementariedad, la cual está basada en que "los sistemas escrito/imagen se dirigen a un solo canal de percepción: la visión” (Costa, 2007, p. 39).

A lo largo de la historia ha existido una separación y, podríamos decir, conflicto, entre la imagen y el texto. Cada uno de estos lenguajes es autónomo; la escritura está asociada con el pensamiento racional, mientras que las imágenes con el pensamiento mágico (Costa, 2007, p.44). Sin embargo, el diseño gráfico "consiste en crear una serie de interacciones entre ellos, que podemos llamar un sistema bimedia. En él, ambos modos de expresión se conjugan, colaboran, se refuerzan a favor de la mayor funcionalidad comunicativa y la mayor expresividad" (Costa, 2007, p. 44). El objetivo es que “la imagen completa al texto, entregando 'datos' adicionales que contextualizan al mensaje" (Reina, 2011, p. 150).

\section{- Color}

Definitivamente el color es un elemento primordial en el mundo del diseño. Cada color tiene una fuerza distinta y especial para expresar algo. Como establece 
Costa: "El color así considerado [como intencionalidad expresiva por parte del diseñador] es un elemento más del sistema gráfico, en pie de igualdad con las formas, las imágenes y los signos, sean tipográficos o icónicos” (2007, p. 57).

Algo que tiene mucha importancia es la utilización del color y la aplicación que se le dé según las intenciones del emisor visual. "Una de las características esenciales del lenguaje visual es el color. Su capacidad de atraer la atención y mantenerla, unida a su capacidad de sugerir y establecer asociaciones semánticas" (Gamonal-Arroyo y García-García, 2015, p.51). Además, es cuestión de ver qué lugar tiene en la composición y en relación a los demás elementos, pues de esta manera es que adquiere protagonismo (Costa, J., 2007).

En el caso de Okinawa, sus colores son bastante llamativos. Utilizarlos en este proyecto, respondería a los efectos que sostiene Costa cuando dice que ayudarán a "detener la mirada por la fuerza de los colores y asociar esta impresión a la marca" (2007, p. 58). Si bien es cierto no se trata solo de una marca la que se establecerá, sino que además se determinará una línea gráfica que permita asociar la paleta cromática a los colores típicos de Okinawa. Y este estilo se mantendrá a lo largo del material a realizarse.

\section{- Tipografía}

Las tipografías tienen un valor importante a la hora de expresar contenido y despertar emociones en los públicos a los que una pieza gráfica se dirige. Estas "pueden generar estados emocionales, redundar el mensaje linguiístico e incluso ser consideradas como elementos significantes que generan significaciones y favorecen la interpretación del texto visual” (Pérez, 2011, p.270). 
En ese sentido, podemos tener la certeza de que cada tipografía es capaz de trasmitir algo particular en un contexto dado. Nos encontramos con fuentes gruesas, delgadas, cuadradas, dibujadas, con serif, sin serif, etc. y cada una habla de un modo distinto. Así, "las fuentes tipográficas manifiestan personalidad propia, desde los elementos plásticos que la conforman” (Pérez, 2010, p. 12) y además es importante resaltar que "cuentan con un alto poder discursivo y llevan inmersa en sí mismos la posibilidad de sobrepasar su dimensión lingüística” (Pérez, 2011, p.271).

Por eso es importante, conocer al público al que se dirige, así como tener bien claro el objetivo de diseño para poder expresar correctamente el mensaje:

Desde el punto de vista del diseño, la elección de una fuente tipográfica no puede darse en principio de manera arbitraria, pues involucra un proceso cuidadoso de selección en el que se tienen en cuenta factores como tema, contexto, público hacia quien se dirige el mensaje, composición, color, entre otros (Pérez, 2010, p. 12).

Finalmente, al elegir una tipografía se requerirán ciertos conocimientos que hay que tener en cuenta para no usarlos sin pensar, ya que "el proceso de elección de la tipografía no es arbitrario, pues de ser así se corre el riesgo de obtener resultados desastrosos" (Pérez, 2010, p. 13). Por ello debe hacerse bajo ciertos criterios que garanticen su eficacia: "palabras bien elegidas merecen letras bien elegidas, éstas a su vez merecen que se las componga con afecto, inteligencia, conocimiento y habilidad" (Bringhurst, 2008).

\section{- Formas}


Las formas tienen un papel fundamental a la hora de hacer diseño gráfico. Como diría Colston (2019), todo diseño gráfico tiene al menos una forma. Éstas están orientadas a dar sentido visual al mensaje que se quiere transmitir. Moreno (2009) define la forma como "un contorno cerrado, un elemento definido por su perímetro" (p. 90) y la describe a su vez como la unión entre líneas y puntos.

Sin embargo, es algo más que el número de límites que tiene un objeto; "la forma perceptual es el resultado de un juego recíproco entre el objeto material, el medio luminoso que actúa como transmisor de la información y las condiciones reinantes en el sistema nervioso del observador" (Arnheim, 2006). Además, como sostiene Arnheim (2006), "la imagen viene determinada por la totalidad de experiencias visuales que hemos tenido de ese objeto, o de esa clase de objeto, a lo largo de nuestra vida" (p.63).

Asimismo, Arnheim (2006) comenta que "la forma sirve, antes que nada, para informarnos acerca de la naturaleza de las cosas a través de su aspecto exterior" (p. 109). Y es importante recordar que "toda forma es semántica, esto es, que sólo con ser vista ya hace afirmaciones sobre clases de objetos" (Arnheim, 2006, p.110).

Es por eso que resulta fundamental reconocer el poder comunicativo que puede tener la forma que se elija para expresar algo en particular. Un diseñador puede distorsionar las formas con un sentido expresivo (Colston, 2019). Hay que tener en cuenta que "la forma no viene determinada sólo por las propiedades físicas del material, sino también por el estilo de representación de una cultura o de un artista concreto" (Arnheim, 2006, p.151). 


\section{K. Diseño de información}

\section{a. Definición}

El diseño de la información es una disciplina relativamente nueva, por lo que su conceptualización se encuentra aún imprecisa. El mismo nombre del diseño de información nos remite a su definición, aunque en realidad hay todo un arte detrás.

Podemos encontrar algunos conceptos como el de Baer (2010), quien menciona que es la traducción de una compleja, desorganizada y desestructurada data en una información valiosa y significativa. La definición de Lipton (2007) complementa a la de Baer, ya que no solo es la organización de la data, sino que la diseña para otorgar una comprensión visual. Él define al diseño de la información como el estudio y la práctica de otorgar claridad y comprensión a materiales visuales hechos para dirigir, enseñar, explicar e informar.

Petterson (2002), por su parte, sostiene que para poder responder ante la necesidad de información que se tiene, el diseño de información analiza, planifica, presenta y comprende un mensaje. Por último, Jacobson (1999) define al diseño de información como el arte y la ciencia de preparar información de modo que pueda ser usado por seres humanos con eficiencia y eficacia.

Podemos observar que para esta rama de la disciplina, no es solo importante el uso de la información sino que tiene un papel fundamental el análisis, la interpretación y organización que se le da, acompañada de un diseño bien logrado. Quizás se puede resumir en que hay información que es muy sencilla y otra que es muy compleja. El truco es hacer la información compleja, comprensible (Bruno Martin en Katz, 2012) y para ello es necesaria una capacidad de análisis y síntesis al iniciar el proceso. 
De este modo podemos decir que un diseñador de la información es como un traductor muy bueno, que es capaz de entender el objetivo y obtener la esencia de la historia o el mensaje (Baer, 2010, p.23)

\section{b. Importancia}

Es evidente que en la actualidad nos encontramos en un entorno lleno de datos cada vez más complejos, para lo cual se vuelve necesaria la aplicación de este tipo de diseño. El diseño de la información ayuda a las personas a hacer una tarea, solucionar un problema o encontrar una necesidad, por lo que minimiza las frustraciones (Lipton, 2007). Asimismo, encontramos su utilidad no solo en el lenguaje y las artes, sino también en la psicología, en las leyes, en las tecnologías (Petterson, 2002).

El objetivo principal del diseño de información siempre estará orientado a la claridad de la comunicación, el cual no se alcanza cuando los intérpretes reciben el mensaje sino cuando lo han comprendido (Petterson, 2002). Para poder cumplir esto, Katz (2012) menciona que los diseñadores tienen que tener en cuenta que existen dos tipos de diseño: el autoreferencial, en donde solo el diseñador entiende, y el pragmático, donde el usuario es quien ha logrado captar el mensaje a plenitud. El propósito del diseño de información debe estar siempre dirigido a que, sin importar el medio o soporte, el usuario llegue a comprender el mensaje porque sino tanto el diseño como el diseñador han fallado (Katz, 2012).

Baer (2010) defiende la idea de que cada uno de estos diseños debe estar centrada en el usuario y no en lo que el cliente o el diseñador piensan que el usuario quiere y necesita. Para eso, también hay que tener en cuenta que habrán obstáculos y que los usuarios tienen distintos modos de absorber la información. Para ello hay que tener en cuenta la atención, percepción, memoria, capacidades de aprendizaje y actitud de cambio de los receptores de la información (Pettersson, 2002). 
Para Petterson (2002), el proceso por medio del cual se realiza con efectividad, debe estar guiado por los siguientes pasos: (1) Analisis y sinopsis, (2) Producción del boceto, (3) Producción del script y (4) Producción del original y versión final.

\section{c. Características}

Para poder realizar un diseño de información que cumpla sus objetivos, un factor muy importante es la claridad. Pettersson (2010) sostiene que la legibilidad en los textos debe evaluarse según el medio en el que es transmitido (hay tipografías creadas para pantallas, otras que se ven mejor para leer en impresos, el tamaño y el grosor de los textos para los carteles en pared debe evaluarse antes de ser elegidos, etc.). Asimismo, las imágenes que se empleen deben diferenciarse, los colores se recomiendan ser contrastados para poder reconocer figura y textos, etc.

Otra característica que expone Pettersson (2010) es la simplicidad. El lenguaje utilizado debe estar acorde con los lectores, siendo de preferencia sencillo y fácil de descifrar. Del mismo modo, las imágenes y símbolos no deben confundir ni complejizar el proceso de lectura. Lipton (2007) argumenta que la simplicidad dependerá de la audiencia, el contexto y otros factores, pero que en la medida de lo posible es mejor tenerla en cuenta mientras sirva completamente a las necesidades de la audiencia. Como recuerda Katz (2012): “las mejores y más comunicativas imágenes y símbolos, son simples y directos, sin elementos externos que reduzcan su poder o lo hagan difícil de recordar".

Una tercera particularidad es el énfasis. De diversos medios se puede lograr llamar y retener la atención del espectador. Dentro de las variables que se pueden emplear para lograrlo se encuentran la complejidad, direccionalidad, la exageración de ciertos rasgos, el humor, o el movimiento (Pettersson, 2010). 
Finalmente, una de las propiedades que debe tener el diseño de información es la unidad (Pettersson, 2010), de modo que todos los elementos que se presenten, cuenten con una relación consistente (tipografía, imágenes, estilo, composición, etc.).

Asimismo, Mijksenaar (1997) dice que la información visual utiliza grandemente las nuevas formas visuales prestadas de la fotografía, del cine, así como también de los comics y las técnicas de ilustración.

\section{d. Utilización del Diseño de Información}

Hoy en día podemos encontrar cada vez más el diseño de información en nuestras vidas cotidianas. Cuando subimos a un auto y vemos las señales de tránsito, cuando buscamos las guías del Metropolitano para saber cómo llegar a la estación deseada, cuando leemos el periódico y vemos cuadros estadísticos, cuando nos dan una guía de museo, cuando vemos las instrucciones para el último electrodoméstico adquirido, cuando visitamos cualquier página de internet, cuando leemos algún libro, etc. (Baer, 2010, p. 26).

\section{K. Documental}

\section{a. Definición}

El documental es una expresión audiovisual que nace en los años treinta. Según Paul Wells, el video documental es una "representación no ficticia que utiliza material actual y del presente, (...) para abordar un tema social particular de interés y que potencialmente afecte a la audiencia” (Tejada y Valencia, 2008).

Como dice Nichols (1997), el documental "no moviliza un inventario finito de técnicas, no aborda un número establecido de temas y no adopta una taxonomía conocida en detalle de formas, estilos o modalidades" (p.42). Este mismo autor puede variar la definición dependiendo de la perspectiva desde la que se aborde. En el caso 
de verlo desde el realizador, se podría diferenciar de otro tipo de creaciones audiovisuales por esto: “A menudo diferenciamos una película documental de una de ficción según el grado de control que se ha ejercido durante la producción” (Bordwell y Thompson en Nichols, 1997, p.42).

Se considera a John Grierson como aquel que "por vez primera pervirtió el adjetivo habitual para emplearlo como sustantivo”. (Breschand, 2004)

\section{b. Metodología}

Es importante destacar que, si bien es cierto la creación de un documental tiene incertidumbre pues no hay un grado de control mayoritario, "no existen documentales hechos sin guión (puede ocurrir que en algún caso el texto original sea mínimo" (Deltell, 2006, p.185). En ese sentido la metodología común utilizada para la creación de una pieza audiovisual (escaleta, guión literario, guión técnico, storyboard, etc.), no se podrá emplear de la misma manera, ni tampoco servirá con efectividad en los documentales.

\subsection{Estado del arte}

A la vista de la problemática que existe, han surgido varias investigaciones y proyectos para poder contrarrestar la desaparición de los idiomas. Entre algunos de ellos podemos encontrar iniciativas que giran en torno a tres tendencias: la clasificación de las lenguas según región/país, la enseñanza del idioma y la exposición del problema.

Sobre la primera tendencia, encontramos First voices (firstvoices.com). Este es una página web muy completa que presenta 52 lenguas nativas del Canadá. Su objetivo es documentar idiomas de comunidades indígenas para que sus futuras generaciones puedan tener conocimiento de ellas. Su forma de trabajo es por medio de equipos con personas mayores que hablan fluidamente estas lenguas y jóvenes que les ayuden a subir diccionarios, 
palabras, historias y frases, tanto en audio como en video a los archivos de cada comunidad. En caso que alguna comunidad quisiera colocar recursos sobre su lengua, sólo tiene que contactarse con la coordinadora del proyecto para iniciarlo.

Cada una de estos idiomas tiene una variedad inmensa de opciones para poder aprenderla. Sus categorías principales son Aprende la lengua (Palabras, Frases, Canciones, Historias y Alfabeto), Juega (Rompecabezas, Búsqueda de palabras, Ordena palabras, Paracaídas, Memoria y Examen), Galería de fotos y Portal de niños (Palabras, Frases, Canciones e historias y Juegos). Definitivamente es un proyecto muy bien elaborado, con mucho trabajo previo de investigación y con contenido creado para ser compartido en este medio. Por ejemplo, en la sección de palabras y frases, se pueden encontrar éstas por escrito, pero también se cuenta con un audio que ayuda a conocer la pronunciación, así como algunas imágenes referenciales para poder captar mejor el significado de lo que se quiere enseñar.

Además de la web, este proyecto incluye las plataformas de juego para niños FirstVoices Kids, las clases personalizadas de FirstVoices Language Tutor, los equipos electrónicos del FirstVoices Language Lab para desarrollar las lecciones correctamente, los FirstVoices Dictionary Apps para ser utilizados en los dispositivos de Apple y FirstVoices Keyboards con teclados en más de 100 idiomas para ser descargados y empleados en los celulares.

Asimismo, podemos encontrar el portal native-languages.org. Ha sido creada por una organización sin fines de lucro llamada Native Languages of Americas, dedicada a preservar y promover más de 800 lenguas indígenas que se encuentran en peligro de extinción en este continente, entre las que están el quechua, el aymara, el asháninka, entre otros. Cuenta con recursos online de diverso tipo, con una clasificación por familias lingüísticas, con libros enfocados en temas de los idiomas nativos americanos, y links variados. Dentro de cada 
idioma se presenta un vocabulario con imágenes, frases típicas, y algunos cuentan con ejercicios.

Lo asombroso de esta página es la recopilación de tanta información en un solo lugar que expresa el interés y la preocupación no solo por la propia lengua materna, sino la conciencia de que la pérdida de un idioma, implica la pérdida de una cosmovisión. Además, se puede observar claramente que su interés es sobretodo una preocupación cultural, puesto que en la sección "cómo puedes ayudar" mencionan 12 maneras de colaborar con el proyecto y solo una de ellas habla del tema económico. Las demás están relacionadas con hablar, escribir y enseñar para promocionar estos idiomas con el fin de que no mueran. Estas recomendaciones están dirigidas según la situación en que se encuentre el aportante. Por ejemplo, el primer punto se dirige a los que son indios nativos y se les dice que la mejor manera de contribuir con este proyecto es que hablen su idioma, lo practiquen con los suyos y lo enseñen a sus hijos. La segunda recomendación está dirigida a los que hablan una lengua fluidamente o conocen a alguien que lo hace, diciéndoles que graben audios de personas hablando el idioma, pues escuchar el ritmo y los sonidos es importante para aprender una lengua. También esto permitirá que en un futuro, otras generaciones puedan interesarse y hasta ser quienes tomen iniciativas para revivir un idioma. De esta manera se va pidiendo la colaboración de los que escriben, los que leen, los que tienen habilidades lingüísticas, los que cuentan con destreza para la tecnología, etc.

En la actualidad en nuestro país solo hay un material relacionado con la lengua uchinaaguchi. Es un diccionario okinawense - castellano realizado por Munetaka Ganaja (2016). La primera edición fue realizada con el apoyo del gobierno de la prefectura de Okinawa y la Universidad de Ryukyu. Esta publicación es muy importante puesto que es el primer diccionario en nuestro idioma en relación al uchinaaguchi y esto permite que los hispanohablantes puedan tener acceso a ella. Antes, para aprender esta lengua era necesario 
saber japonés (pues la mayoría de los textos y ejercicios están en este idioma) o inglés (aunque es más conocido, igual no es lengua materna y hay muchos cabos sueltos en sentido lingüístico y gramatical).

Por otro lado, existe un artículo sobre los esfuerzos de mantener el uchinaaguchi en Sao Paulo (Petrucci \& Miyahira, 2010). En éste explican cómo se ha desarrollado, en primer lugar, el idioma en Okinawa y luego en Brasil. Existen algunas iniciativas en Brasil como en Jornal Utiná Press, boletín mensual, que incluye unas lecciones básicas de uchinaaguchi. Asimismo, hay un interés por parte de algunos jóvenes descendientes de Okinawa que utilizan este idioma en la música y obras de teatro.

El texto también explica cómo se desarrolló un curso de uchinaaguchi en Vila Carrao en el 2010. Fue una clase dirigida a personas en la comunidad y se inscribieron 14 alumnos. El director de la escuela y su hermano estaban convencidos de que el uchinaaguchi representa el poder de la cultura okinawense y por ese motivo debería mantenerse vivo en la medida de lo posible. Estas clases de tres horas semanales tuvieron la siguiente estructura: primero, la discusión de un proverbio; luego, el estudio de un cuento popular comprendiendo su significado; posteriormente, se profundiza en estructuras gramaticales por medio de la explicación de la profesora y la creación de diálogos cotidianos; finalmente se emplean diferentes medios (audios o videos) para poder complementar la información recibida.

En relación a la última tendencia, encontramos el proyecto "Invisible languages: Okinawa", el cual acaba de finalizar su proceso de financiamiento exitosamente en la plataforma de crowdfunding Kickstarter. Esta iniciativa es la producción de un documental cinematográfico dirigido por tres jóvenes de distintos países, entre ellas una descendiente de Okinawa. Ellas buscan dar a conocer la problemática de la extinción de las lenguas de este archipiélago, contando cómo es que ha sido este proceso. En este trabajo audiovisual 
presentan antecedentes y testimonios que permitirán conocer de cerca las dificultades que están alrededor.

Una iniciativa didáctica y entretenida es Let's sing uchinaaguchi. Su plataforma principal es Youtube y por este medio presenta videos animados de canciones donde se enseñan los saludos y palabras básicas en uchinaaguchi. Sus melodías sencillas permiten una fácil recordación de las palabras. Su público objetivo son los niños, lo cual resulta muy interesante puesto que aprender un idioma a temprana edad permite que crezcan familiarizados con el idioma. 


\section{Capítulo II}

\subsection{Análisis del público objetivo}

El público objetivo al que se dirige el presente proyecto es a jóvenes nikkei peruanos que han participado de becas a Okinawa. Estas experiencias son otorgadas por diferentes instituciones a descendientes de esta zona de Japón, que tienen entre 13 a 35 años, por lo que la edad del público al que nos dirigimos está dentro o sobre este rango etario. Según el tipo de beca (pueden ser a nivel distrital o prefectural), la estadía puede durar entre un par de meses y un año, habiendo opciones de conocimiento cultural y de idioma japonés, así como experiencias profesionales en algunos casos.

Ellos han tenido la oportunidad de sentir la cercanía de Okinawa como el hogar de sus ancestros. El hecho de estar en ese lugar les aumenta el deseo de saber más sobre sus raíces (costumbres, danzas, música, arte, relaciones familiares, etc.), despertando en ellos el respeto y consideración hacia ciertas tradiciones que los migrantes buscaron conservar en sus nuevos destinos. Además, crece en ellos el sentido de identidad okinawense.

Asimismo, estando allá, en algunos casos se les suele enseñar lo básico del idioma uchinaaguchi para poder presentarse en algunos eventos, por lo que han tenido contacto incipiente con el idioma. De igual modo, esta beca les ha permitido conocer a algunas personas que son nativas de la lengua.

Algunos becarios, al volver a Perú se han dedicado a compartir lo aprendido en su estadía, en algunos casos creando escuelas o dictando cursos de danza, instrumentos, cocina, etc. Sin embargo, las expresiones artísticas han sido lo más difundido pero la parte de la lengua no ha sido tomada en cuenta.

Para estos jóvenes, el uchinaaguchi es un idioma ajeno y no se sienten ligados a él, por lo que no suelen preocuparse en aprenderlo. Conocer esta lengua no les favorece en sentido profesional por lo que invertir tiempo en su aprendizaje no resulta atractivo ni beneficioso. 
No obstante, la lengua materna de sus ancestros está en peligro de extinción y conocer al menos lo básico de ella, les permitirá conservar en cierto sentido el recuerdo y la herencia de Okinawa.

Por los motivos expuestos, se decidió elegir a este público objetivo. Los becarios quizás sean los jóvenes más vinculados a sus orígenes okinawenses, que si bien es cierto, puede que no hayan aprendido mucho sobre la lengua, han comenzado a querer y a valorar a Okinawa y esa es una razón que los puede llevar a preocuparse e interesarse por la posible pérdida definitiva de algo relacionado a este lugar. Lo más probable es que la mayoría de ellos no sepan de la gravedad de la situación en la que se encuentra el idioma.

\subsection{Proyecto}

El proyecto consistirá en la aplicación de diseño de información en un corto documental como herramienta de difusión sobre el peligro de extinción de la lengua uchinaaguchi.

En cuanto a la pieza de video, tratará sobre una recopilación de datos estadísticos que permitan conocer la realidad en la que se encuentra este idioma. También se empleará una narrativa que les haga recordar a sus ancestros y a su experiencia vivida en Okinawa. Para ello se incluirán entrevistas a especialistas y personas que hayan tenido cercanía con el idioma.

Asimismo, uno de los énfasis que se querrá dar es que el hecho de que una lengua se encuentre en peligro de extinción implica que las expresiones culturales (danzas, cantos, relatos populares, frases, etc.) perderán una fuente viva de interpretación de significados. Por tal razón, se utilizarán tomas de apoyo de las expresiones artísticas que argumenten visualmente ese discurso. 
También le daremos una fuerza especial al diseño de información para que sirva de herramienta para resumir los datos presentados en el documental y crear una mayor recordación e interés en el tema.

Por último, concluirá con un llamado a la acción para que ellos se vean involucrados y empoderados en el desafío de aprender al menos palabras y frases básicas en este idioma.

\subsection{Proceso del proyecto}

\section{A. Concepto}

El concepto que se ha definido para este proyecto es el de "nostalgia familiar y a las raíces”. Por lo expuesto acerca del público objetivo, esta idea central invita a despertar en ellos el deseo de estar cerca de sus ancestros. En la mayoría de los casos, son nietos o bisnietos de los primeros migrantes, quienes ya perecieron. En ese sentido, la nostalgia familiar toma un papel fundamental que conecta con sentimientos profundos y recuerdos de momentos que se vivieron juntos. Trayendo esto a la mente, se podrá vincular emocionalmente a lo que haga memoria de los abuelos, como el idioma que usaban.

Este concepto también evoca a las experiencias vividas durante la beca, que tantos sentimientos de identidad y orgullo despertaron en los jóvenes. Estos intercambios surgieron hace aproximadamente 30 años debido a que las comunidades okinawenses en Sudamérica estaban perdiendo contacto con las autoridades e instituciones de la prefectura japonesa, y dificultaba poder augurar un porvenir que vislumbre relaciones óptimas con las futuras generaciones de descendientes. En ese sentido, estas becas han permitido a los participantes encontrarse con sus familiares que viven allá, que en la mayoría de los casos no conocían. De este modo, intercambiar lazos con los hermanos, tíos, primos o parientes de los abuelos también responde a este sentimiento de nostalgia familiar. 
Asimismo, "nostalgia a las raíces" porque conlleva al deseo de conservarlas, pues vincula a los orígenes personales y la conexión generacional. De este modo, Okinawa aparece como el lugar que encierra toda esa riqueza. Además, estos jóvenes serán conscientes de que si no aprenden ahora la lengua, quizás hayan menos posibilidades de que lo aprendan luego.

También se juega con el sentir de que si no se toman acciones, se perderá algo que era muy valioso para los abuelos, la lengua en que se comunicaban, en la que estaban sus danzas y canciones favoritas, sus cuentos e historias, etc.

Este concepto no tiene solo un aspecto negativo, sino que invita a tener esperanza en lo que se puede lograr. Este sentimiento impulsa a interesarse en el tema y a tener conciencia de que hay mucho por hacer, sirviendo como motivación para revalorar la lengua.

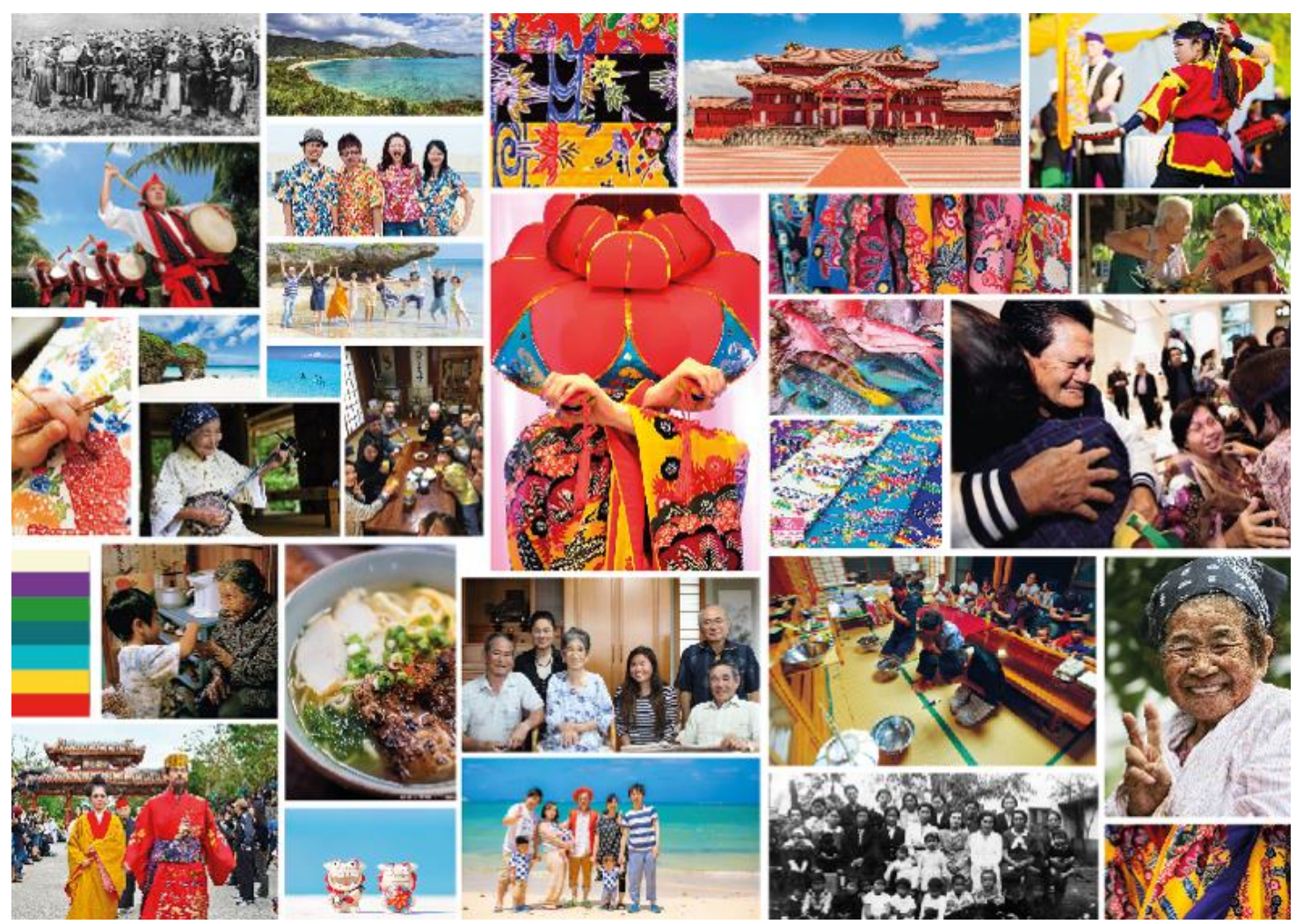

Imagen 1. Moodboard de imágenes de Okinawa 
El moodboard refleja la esencia okinawense, expresado en momentos familiares cargados de sentimientos por medio de sonrisas o abrazos. Los grupos de personas que se observan incluyen varias generaciones unidas (abuelos, padres, hijos). Además, el butsudán (altar okinawense) representa la conexión que se tiene con los antepasados, pues ahí se les rinde culto y veneración, remitiendo al concepto.

\section{B. Nombre del proyecto}

"Uchinaaguchi: el idioma de oji y oba"

El nombre elegido para el proyecto contiene la combinación de un elemento nostálgico para despertar en cada uno de los lectores el interés, la preocupación y la responsabilidad personal por hacer algo para que esta lengua no muera.

Tiene dos partes. "Uchinaaguchi”, deja en claro el marco en el que se encierra, pues los que conocen el término saben de qué se trata, y los que no, lo descubrirán en la descripción de la segunda parte.

"El idioma de oji y oba": Utilizando el concepto de nostalgia familiar, se quiere crear una vinculación emotiva con los lectores, pues contiene el término oji (abuelo en japonés, dicho con cariño), que es utilizado por la mayoría de los descendientes nikkei en Perú y que remite a la cercanía y a las memorias con el abuelo.

\section{Identidad de Marca}

\section{a. ADN de Marca}

Dentro de la cultura vivida en la marca, se transmitirán los valores okinawenses como el respeto, la solidaridad, la acogida, la preocupación por el otro, la laboriosidad y la honestidad. No obstante los valores propios de la marca son sentido de comunidad, cercanía, optimismo y honestidad.

Propósito: Por medio de este proyecto se busca sensibilizar al público objetivo con el fin de que pueda despertarse en ellos el interés por 
uchinaaguchi. Se trata de una lengua que no es propia de aquí ni mucho menos utilizada, por lo que resultará muy difícil revivirla. Sin embargo, se busca que los descendientes de okinawenses puedan conocerla e interesarse, y así valorarla como algo que está presente en las diferentes expresiones artísticas de la cultura de Okinawa.

Promesa: A través de la concientización de la pérdida del idioma que va relacionada con la cultura okinawense, se buscará crear el anhelo por hacer algo para rescatarla.

Posicionamiento: Buscamos posicionarnos como la marca social preocupada e interesada en la preservación de la lengua uchinaaguchi entre los descendientes de okinawenses, siento un referente de compromiso no solo a nivel nacional sino también internacional.

Personalidad: La marca tiene interés sincero por las raíces okinawenses, habla con creatividad, pues quiere que los mensajes que transmita sean acogidos con apertura y simpatía. Asimismo, es amigable, ya que por medio de la confianza y la cercanía que se genere se fortalecerá la relación con los seguidores.

\section{b. Fuerza Marca}

Para poder establecer una marca consistente, hay que tener en consideración factores internos:

Claridad: Está vinculada con los valores de marca. Dentro de estos elementos se encuentran el sentido de comunidad, direccionado a trabajar en conjunto, conociendo la fortaleza de la comunidad okinawense; la cercanía, pues se buscará hablar desde el corazón, con el sentido de icharibachoode - "una vez que nos conocemos, somos hermanos"-, que 
caracteriza a los okinawenses; optimismo, ya que se darán mensajes pensando que el trabajo que se realiza dará algún tipo de fruto a la comunidad, enfocando en la esperanza ante el problema planteado; y la honestidad, por medio de la información estadística veraz, y los testimonios reales se busca que los seguidores puedan creer en lo que decimos.

Compromiso: Se buscará involucrar por medio de la responsabilidad y de este modo hacer que otros se puedan interesar por el idioma, así como la familiaridad, que es uno de los factores que llevarán a comprometerse con el proyecto.

Gobierno: La organización interna ayudará a que el proyecto avance con eficacia. Dentro de este, hay temas como el organigrama, que consiste en un director del proyecto, un equipo audiovisual, un equipo de redes sociales y un equipo de logística; etapas de producción, s importante poder tener estructurada las funciones que realiza cada equipo, con el fin de lograr los objetivos; el cronograma, manteniendo el orden y cumpliendo las fechas para terminarlo a tiempo (preproducción, producción, post producción, promoción, presentación/evento); protocolo de proyección, que permite que en caso se realice la proyección en distintos lugares, la experiencia sea la misma.

Por otro lado, hay factores externos para tener en cuenta:

Autenticidad: Es una factor que permitirá el enganche con la audiencia. La información veraz, la voz real de alguien en el video, los testimonios y los datos estadísticos brindarán credibilidad a la marca. Por otro lado, el espacio donde se va a realizar la proyección debe tener la característica 
inmersiva (música, objetos, puesta en escena) para poder crear la experiencia multisensorial relacionada a la cultura okinawense.

Diferenciación: Los valores diferenciales en este proyecto son que no hay productos similares (no hay trabajos que se enfoquen en el tema de esta lengua y además que esté en español) y el aporte del diseño de información en los videos a través del motion graphic, para crear dinamismo y captar la atención en un tema que puede resultar un poco tedioso.

Relevancia: El tema y la problemática despierta un interés en el público objetivo, que ya ha cultivado de algún modo su cercanía a Okinawa.

Consistencia: Las redes sociales mantendrán un tono de comunicación cercano, familiar y que trata de enseñar algunas cosas acerca del idioma, así como invitar a participar en las redes (Instagram, Facebook y Youtube). Asimismo, la identidad visual mantendrá la paleta de colores especificada (rojos, amarillos, morados, celestes y verdes) y habrán tramas que remitan a lo okinawense.

Engagement: Toda la campaña comunicacional tendrá un call to action para que el contenido se pueda compartir (“destaca la parte más emocionante del trailer y compártelo con alguien”). Además será un llamado a la conciencia, para crear un anhelo por ver el documental. Por último, utilizaremos fotos de abuelos, que nos ayudarán a que se sientan identificados.

\section{Diseño de marca}

\section{- Logotipo}




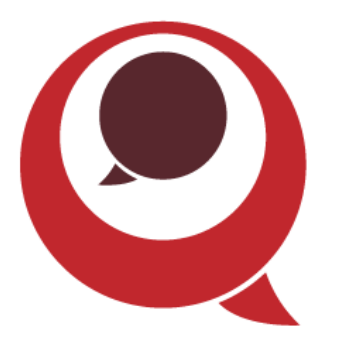

\section{UCHINARGUCHI}

El idioma de oji y oba

\section{Imagen 2. Logotipo del proyecto}

El logo está compuesto de dos elementos gráficos que sintetizan aquello de lo que trata el proyecto. Por un lado, observamos la referencia al escudo de Okinawa, que incluye un círculo rojo, rodeado de uno blanco y circunscrito en otro rojo más grande.

Asimismo, las formas que aparecen son globos de diálogo que representan todo lo relacionado con la lengua, con la conversación, con el intercambio de ideas, etc.

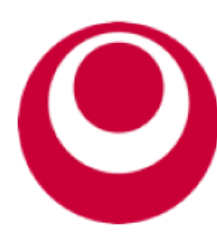

Escudo de Okinawa

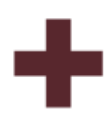

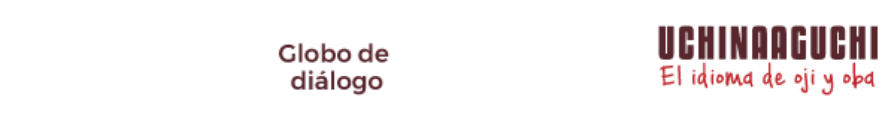

Imagen 3. Construcción del logotipo

\section{- Tipografía}

Las tipografías utilizadas son Kenyan Coffee para "uchinaaguchi” y Cashew Apple Ale para "El idioma de oji y oba". La primera se eligió porque al ser una palabra larga, se requería una fuente que sea angosta y tenga buena altura para no expandir mucho las letras. A su vez, ésta otorga firmeza y llama la atención por 
de tipo bold. Se empleó solo para esta palabra pues es lo central del corto documental y se quería diferenciar del otro texto.

Por otro lado, la segunda tipografía buscaba transmitir jovialidad, puesto que es un proyecto dirigido a jóvenes. Ésta, al ser caligráfica, remite también a algo más cercano y familiar, como es el tema a tratar y el mensaje de el texto que se escribe (“el idioma de oji y oba”).

\section{- Color}

El color principal será el rojo. Este color remite al escudo de Okinawa, aunque en este caso se empleen dos tonos para diferenciarlos. Del mismo modo, la diferencia de tamaño y color dan la sensación de que el grande se consume al pequeño, que se encuentra ensombrecido.

Este color también es representativo del castillo Shuri y del hanagasa (sombrero en forma de flor utilizado en una danza típica), ambos típicos de este archipiélago. Como sostiene Heller (2004), “el efecto psicológico y simbólico de la sangre hace del rojo el color dominante en todos los sentimientos vitalmente positivos" (p.55), como la vida y la felicidad.

Por otro lado, se utilizará una variedad cromática, como colores secundarios, para ser empleados en las diversas piezas de comunicación. Estos se obtuvieron del moodboard y ayudan a expresar el concepto del proyecto reflejando tanto la variedad cromática de la cultura okinawense como de sus paisajes. Estos serán utilizados en diferentes aplicaciones, tanto para redes sociales, diseños impresos y animaciones dentro del corto documental. 

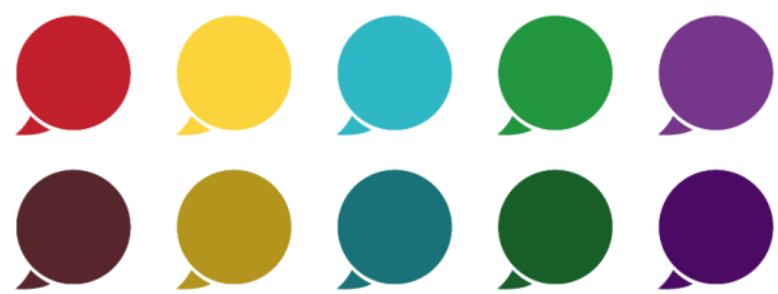

Imagen 4. Colores que expresan la esencia cromática de Okinawa

\section{- Prisma Kapferer}

Esta herramienta permite resumir tanto los conceptos de marca como los elementos del diseño expuestos. De este modo, se puede corroborar que el logotipo responde a factores que fortalecen la identidad.

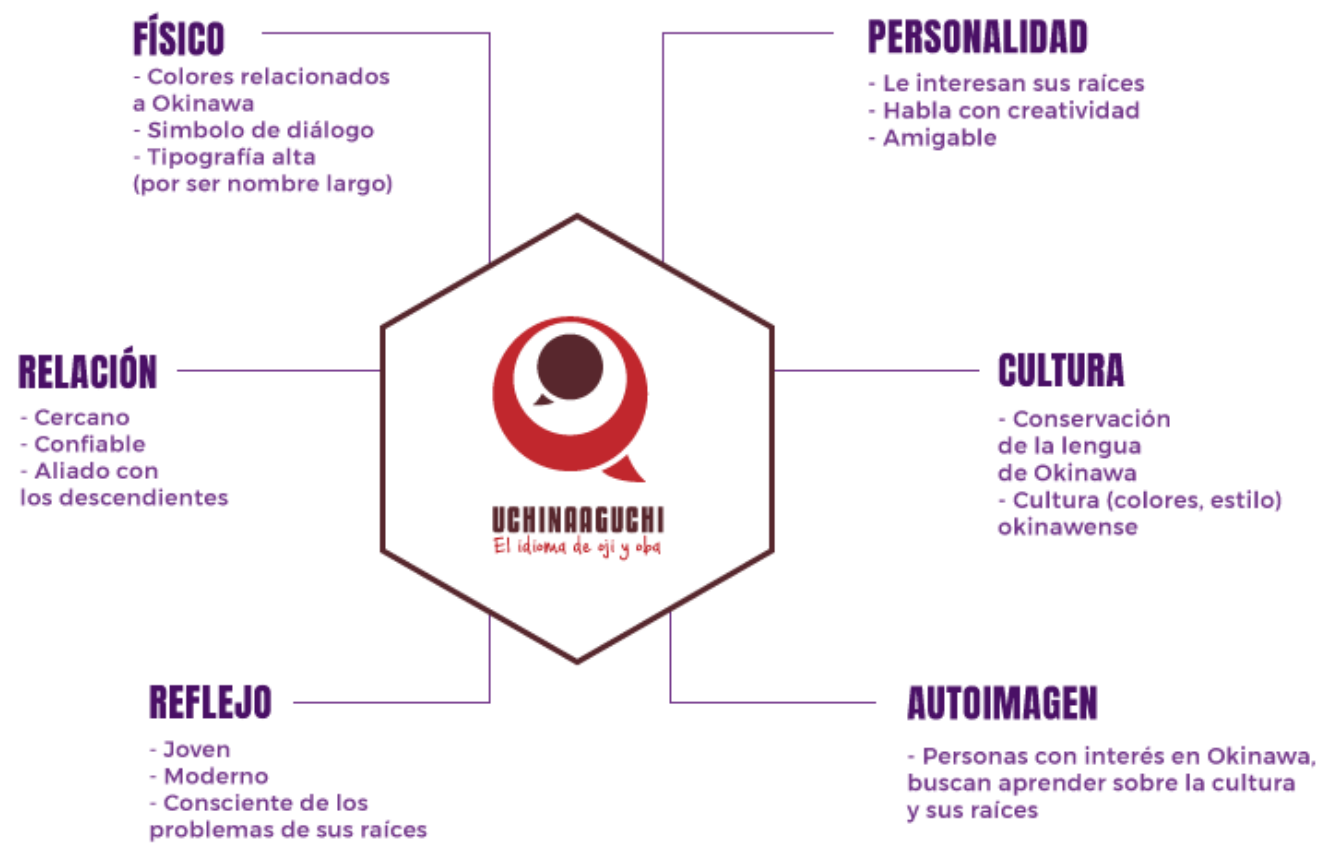

Imagen 5. Prisma Kapferer aplicado a la marca

\section{E. Fundamentación del proyecto}

El problema al que nos enfrentamos es la extinción del idioma uchinaaguchi entre los descendientes de okinawenses en el Perú. Es por ello que nace esta iniciativa que 
permite dar a conocer esta realidad, para así, acrecentar la necesidad de valorar y aprender este idioma entre nuestro público objetivo. Es importante mencionar que no existen proyectos audiovisuales que se preocupen por este tema en nuestro idioma.

Según el estudio realizado se ve claramente que la lengua ha estado perdiendo fuerza en los últimos años. El hecho de que tenga el rango de peligro de extinción es un problema latente y en el entorno peruano muy pocos hablan este idioma. Uno de los motivos es que los primeros migrantes, al iniciar la segunda guerra mundial y al quedar Japón devastado, decidieron hacer su vida aquí, para lo cual no era necesario enseñar a sus hijos ni japonés ni uchinaaguchi. Esto hizo que se perdiera la continuidad.

Actualmente, la mayoría de jóvenes que han tenido cercanía con el idioma, son los que han ido de beca, y para ellos el único contacto que han tenido ha sido durante el período de tiempo de su permanencia en Okinawa.

Somos conscientes que no queremos que los jóvenes terminen conversando en uchinaaguchi. Sin embargo, conocemos que la necesidad de que sepan que no solo han disminuido el número de hablantes sino que está en peligro de desaparecer, es un mensaje que podría motivar, sirviendo como motor para aprender más sobre esta lengua. De esta manera pueden honrar a sus ancestros, conservando el legado lingüístico que se está perdiendo.

\subsection{Diseño de la comunicación}

A este público objetivo se llegará por diferentes medios. En primer lugar, se hará una campaña gráfica impresa (afiches, folletos) que se colocará en los locales donde los jóvenes acuden (por eso se eligió la APJ y la AOP). Asimismo, se contactará por grupos y páginas de redes sociales donde se encuentren estos becarios (Kimutaka Ex Becarios Peru Okinawa, Asociación Okinawense del Perú, entre otros). También se puede llegar a ellos mediante los contactos en común en espacios digitales, así como por los grupos de Whatsapp que existen 
entre ellos. Se contactará con el Departamento de Becas de la AOP para solicitar una base de datos del público objetivo.

Lograremos que se entienda el mensaje por medio de la narrativa del corto documental, pero sobretodo por la aplicación efectiva del diseño, tanto en el diseño de información como en la línea gráfica que se empleará a lo largo de todo el documental. De este modo nos aseguraremos su interés.

Lo que más importa es que se puedan quedar con el mensaje de la situación del idioma, de las causas que ocasionaron su actual problema y que estén deseosos de poder aprender algo de esta lengua. Para ello, se les otorgará a los participantes un breve resumen para que puedan guardar, y así recordar los puntos clave que se trataron en el documental.

Al tratarse de un proyecto digital, las redes sociales, y en especial Youtube, permiten el almacenamiento a largo plazo del contenido que se realizará. De este modo se garantiza su permanencia.

Los medios que se utilizarán en este proyecto son impresos (afiches de promoción volantes, volantes informativos y resúmenes de datos), digitales (afiches para redes sociales) y audiovisuales (el documental).

El proyecto tiene cinco etapas:

1. La primera consta de la creación del documental, que implicará la preproducción (planificación e investigación), la producción (filmación) y la postproducción (edición y efectos).

2. Con esa pieza audiovisual, nos presentaremos a la Asociación Peruano Japonesa y a la Asociación Okinawense del Perú para presentarles la posibilidad de proyectar el documental en sus locales.

3. Una vez aceptado, daremos el paso a la difusión del evento de proyección del documental a través de material gráfico. 
4. Proyección del documental en las instituciones mencionadas. Allí se repartirá un volante donde se indique el link del documental que estará disponible a partir de una fecha determinada.

5. Una vez terminado el lanzamiento del documental en las instituciones nikkei más importantes, pasaremos a una campaña de lanzamiento por redes sociales, que se apoyará de las plataformas de las asociaciones e influencers relacionados al publico objetivo y a la temática.

\section{A. Receptor}

El público objetivo son los jóvenes de ascendencia okinawense que viven en Perú y que han participado de una beca a Okinawa. Tiene entre 18 y 35 años, concentrados principalmente en Lima. Además, los valores okinawenses han sido transmitidos por sus padres, abuelos o bisabuelos, los cuales conservan y practican. Sin embargo, mantienen muchas tradiciones, pero no suelen comprender sus significados.

Principalmente pertenecen a los NSE B, aunque están también en otros. En su mayoría viven en Jesús María, Pueblo Libre, San Borja, La Victoria y el Callao. Se encuentran cursando la universidad o son profesionales.

Asimismo, al volver de las becas, tienen un sentido de gratitud por la oportunidad de haber podido viajar, lo cual se ve manifestado en la participación en las instituciones que les otorgaron el intercambio (sean reuniones mensuales, trimestrales, o anuales).

\section{B. Emisor}

En este caso el emisor es el investigador de este estudio, que a su vez es joven sansei, descendiente de Okinawa. Asimismo, ha sido becario, participando de esta experiencia en el año 2015 en Ginoza (3 meses).

\section{Canales y medios}


Como ya se mencionó, se utilizarán distintos canales y medios para poder alcanzar al público objetivo. Entre ellos están los diseños impresos que se colocarán en los locales donde se realizará el evento (afiches, volantes, trípticos, resúmenes, etc.). Por otro lado, mediante las redes sociales se comunicará información sobre el proyecto mediante afiches digitales, pequeños videos y algunos anuncios. Finalmente el corto documental se subirá a Youtube.

\section{Mensaje}

Por distintos medios se buscará transmitir la realidad de la lengua y su situación de peligro y que es importante que se aprenda algo de ella. De este modo, se despertará en el público objetivo, la preocupación y el interés animándolos a conocer y aprender lo básico de la lengua. Es importante difundir esta información porque no se tiene conciencia de que en unas décadas esta lengua se puede perder.

\subsection{Estudio de la comunicación}

\section{A. Sintaxis}

El mensaje contará con una primera parte que te haga cuestionar y reflexonar sobre el conocimiento y la actitud ante el problema. Luego se aterrizará en la realidad del Perú para dar a conocer cómo es que a nivel local esta lengua también se encuentra en peligro. Finalmente, se planteará enseñar algunas palabras en el idioma para motivar el uso de este. Todo esto se verá reflejado a lo largo del documental y en la ficha resumen final. De este modo, se interrelacióna el diseño de información con lo audiovisual. Posteriormente, se combinará con el uso de las redes sociales como campaña de difusión.

\section{B. Estética}


En cuanto al estilo gráfico, se buscará mantener los colores típicos de los diseños de Okinawa (bingata), así como las formas, líneas y trazos utilizados en esta técnica de diseño.

\section{Simbología}

Los colores que se empleen, están de alguna manera relacionados con los mencionados de Okinawa. Sin embargo, utilizaremos los colores vivos y encendidos de esta prefectura representando de algún modo que toda la riqueza no solo cultural, sino también cromática, podría perderse. Utilizaremos los elementos representativos para poder crear relación directa con Okinawa.

\section{Pragmatismo}

Se optó por realizar un corto documental porque su parte visual tiene un alto valor estético para los jóvenes durante su uso de las redes sociales y les llaman la atención más que solo textos o fotografías. Asimismo, las tomas ayudan a conectar con mayor eficacia la parte emocional y sentimental, que capta la atención mediante el storytelling, lo cual se refuerza con la música. Es importante destacar que un trabajo documental genera credibilidad, debido a la autenticidad de los testimonios y eleva el interés de los espectadores por conocer más acerca del tema. De igual forma, existirá una parte racional que ayudará a comprender mejor numéricamente lo que ocurre. En base a estos componentes se buscará lograr en el público objetivo el interés, preocupación y responsabilidad. 


\section{Capítulo III}

\section{A. Introducción}

Nos presentamos ante el problema de cómo aportar a través del diseño a la preservación de la lengua uchinaaguchi, que se encuentra en peligro de extinción. Con esta premisa se inició la creación del diseño de información para el documental, que se realizó recolectando la información para crear el guión del documental (Ver Anexo 3). Una vez que se tenía el guión, se extrajeron los datos que se querían resaltar para comunicar y diseñar.

Ante esta situación, se descubrió que la información se podía clasificar, que habían cosas en común y se podían categorizar a pesar de que aparecían en diferentes partes de la historia. Esta información se podía colocar al final, y se pensó en una infografía que resuma todo lo prioritario que se ha presentado en el documental, y así, esta herramienta gráfica serviría para retener y reforzar los datos.

A partir de eso, se empezó a trabajar y a emplear una nueva fórmula para utilizar diseño de información en un documental, que sea replicable en otros proyectos. Esta será la primera pieza gráfica que se presentará, debido a su aporte en el diseño.

Asimismo, para poder expresar mejor la fórmula, también se presentará la explicación detallada de esta con ejemplos del proyecto documental sobre el uchinaaguchi. Este consistirá en los diagramas de datos de diferentes momentos del documental y la infografía final de éste.

En este capítulo se busca debatir y confrontar la propuesta con el fin de que se vea su practicidad, su viabilidad y eficacia. Para poder tener la evaluación se realizaron tres entrevistas a diferentes expertos en el tema: Alfredo Oshiro, infografista que ha laborado más de 15 años en el diario El Comercio; Alicia Alvarez, profesora del curso Diseño de Información en la Maestría de la USIL; y Victor Sanjinez, infografista e ilustrador que ha trabajado en el diario El Comercio, con varias exposiciones individuales y colectivas. 


\section{B. Presentación de propuesta de diseño}

\section{a. Fórmula para utilizar diseño de información en un documental}

Para poder comprender mejor la Fórmula para utilizar diseño de información en un documental, vale la pena reforzar los motivos por los cuales se planteó.

Los documentales nos ayudan a conocer la realidad, pero muchas veces involucran datos importantes que deberían llegar de un modo más óptimo a los receptores, con el fin de retenerlos en la memoria. Si bien es cierto el documental contiene audio y video, visualmente no se suelen mostrar los datos. Esta propuesta busca aprovechar lo visual para crear mejor retención y lograr interiorizar con mayor profundidad la problemática. De esta manera, no solo estará la historia, sino que se alinearán lo audiovisual y lo gráfico para obtener este objetivo de comprensión de la información.

Muchas veces los que ven los documentales se quedan con las historias o algunos acontecimientos presentados. Sin embargo, es importante preguntarnos si esto era realmente lo que buscaba el emisor. ¿Cuánto de lo que él quería decir y compartir con la audiencia, que le pareció información interesante y rescatable, ha sido desplazada?

Asimismo, esta propuesta presenta, no solo el apoyo visual durante el documental, sino que además quiere que los conocimientos se vean plasmados, al finalizar la pieza audiovisual, una infografía general que resuma los datos y que se pueda descargar, imprimir y compartir con otras personas.

Con el fin de recopilar información y crear la narrativa para la producción de un documental, se utilizó la siguiente metodología:

- Lo primero que se realizó fue la investigación de gabinete de los documentos existentes para entrar profundamente a la problemática. 
- Luego, se hicieron las encuestas para poder aterrizar todos estos conocimientos adquiridos en la perspectiva y situación actual de los involucrados.

- A continuación, se hicieron entrevistas a profundidad con los expertos sobre el tema, para poder ahondar en todos los aspectos encontrados.

- Y por último, se logró crear una historia que atraviese lo relevante y, con esta línea narrativa, poder mencionar todo lo que se ha destacado y que pueda generar concientización sobre el tema mencionado.

Por otro lado, la propuesta de la Fórmula para la utilización de diseño de información en un documental, se centra a partir de la selección de los objetivos de comunicación que se quieren tener en cuenta desde el documental, hasta la producción de la infografía final. Por esto se plantean seis pasos:

1. Elección de las preguntas: Con el fin de que la información que se comparta sea importante, se buscará elegir entre las 6 preguntas básicas para obtener información: qué, quién cuándo, dónde, por qué, cómo. Se podrá elegir cuantas se consideren necesarias para los objetivos planteados.

2. Selección y categorización de la información: Cada pregunta elegida será respondida por los datos mostrados en las categorías. El primer paso para seleccionar la información será utilizar el guión, para luego categorizarla. Es importante ponerle un título para que los espectadores puedan entender mejor.

3. Estilo gráfico por categoría: Se desarrollará un estilo gráfico que pueda ser reconocido cuando aparezca en escena (puede ser un color, una forma, un elemento, etc.).

4. Aparición en el documental: Por la dinámica del documental, los datos irán apareciendo en diferentes momentos, pero se distinguirán por las 
características que elegiste. El espectador debe poder reconocer a qué categoría pertenece, aunque no es el objetivo que los asocie, sino hasta el final.

5. Construcción progresiva de infografías por categorías: Antes de que los datos desaparezcan de escena, éstos se moverán dentro del encuadre hasta la posición que ocuparán en la infografía de su categoría.

6. Infografía final: Al terminar el documental, aparecerán los datos en una infografía final que recopilará la información de todas las categorías.

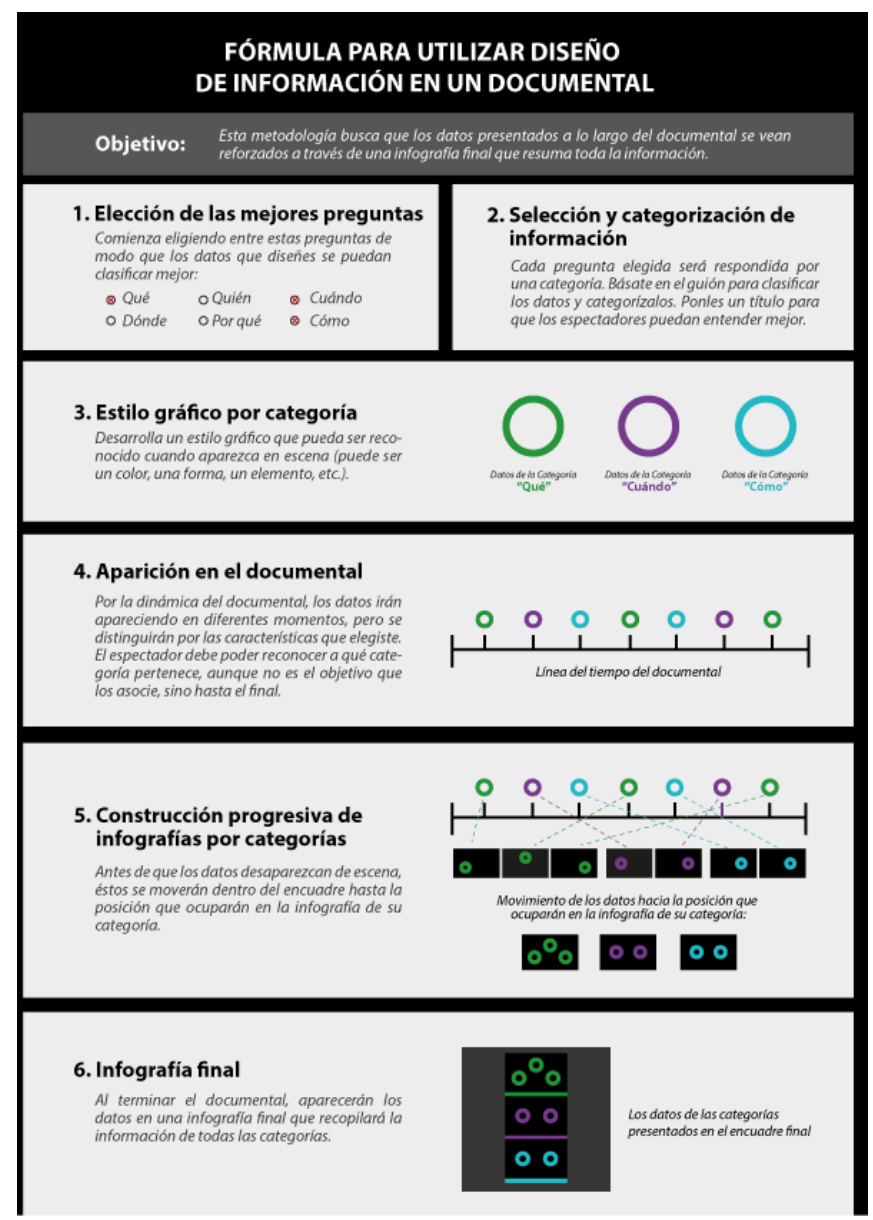

Imagen 6. Fórmula para utilizar diseño de información en un documental

\section{- Consideraciones en diseño}

La línea gráfica debe hacer referencia al tema del que se está conversando y debe remitir constantemente a él. Así, no se sentirá aislado sino 
que formará parte de un todo. Esa línea gráfica servirá como paraguas para todas las demás.

Además, habrán sub-líneas gráficas que deben caracterizarse por elementos especiales y su identidad gráfica debe ser reconocible. Por la naturaleza del documental, no se mostrarán en orden, sino que irán apareciendo en la medida que la narrativa lo permite. Es por ello que deben gozar de una sub línea gráfica específica que permita que el receptor pueda comprender de qué categoría se trata.

Lo importante de haber producido las líneas y sub-líneas gráficas es que todo tenga un orden y al final, en la infografía general, se pueda apreciar un común denominador, pero también una personalidad particular por categoría.

\section{- Aplicación de la Fórmula para utilizar diseño de información en un}

\section{documental}

Para aplicar esta fórmula en el documental sobre el uchinaaguchi, se ha elegido responder a las siguientes preguntas: ¿Qué problema tiene el uchinaaguchi? ¿Por qué sucedió este problema en el Perú? ¿Cómo se puede mejorar esta situación? Ante ellas se ha designado un estilo gráfico que en esta ocasión está basado en el color.

Para la primera categoría (que responde a “qué"), al tratarse de un tema que si no se hace algo podría ocurrir la pérdida del idioma, se optó por el color verde, que representa la esperanza. 


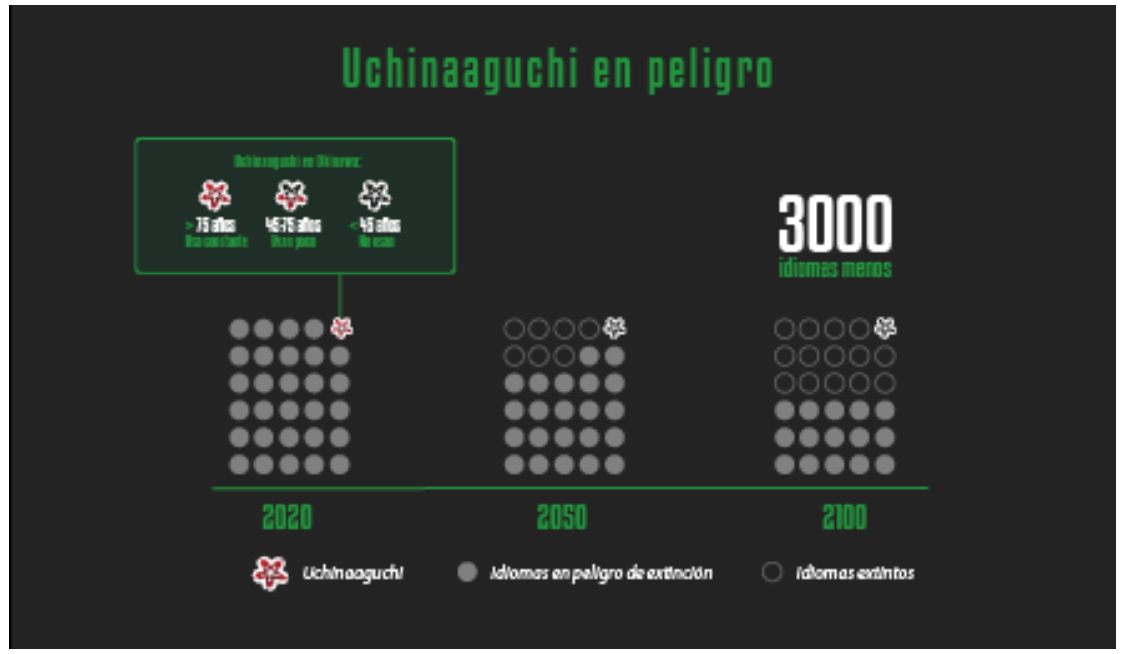

Imagen 7. Uchinaaguchi en peligro, infografía final de la categoría "qué"

La segunda categoría (que responde a "por qué"), implica una parte de la historia difícil para los japoneses y sus descendientes. Por ello se eligió el color morado, que representa melancolía y tristeza.

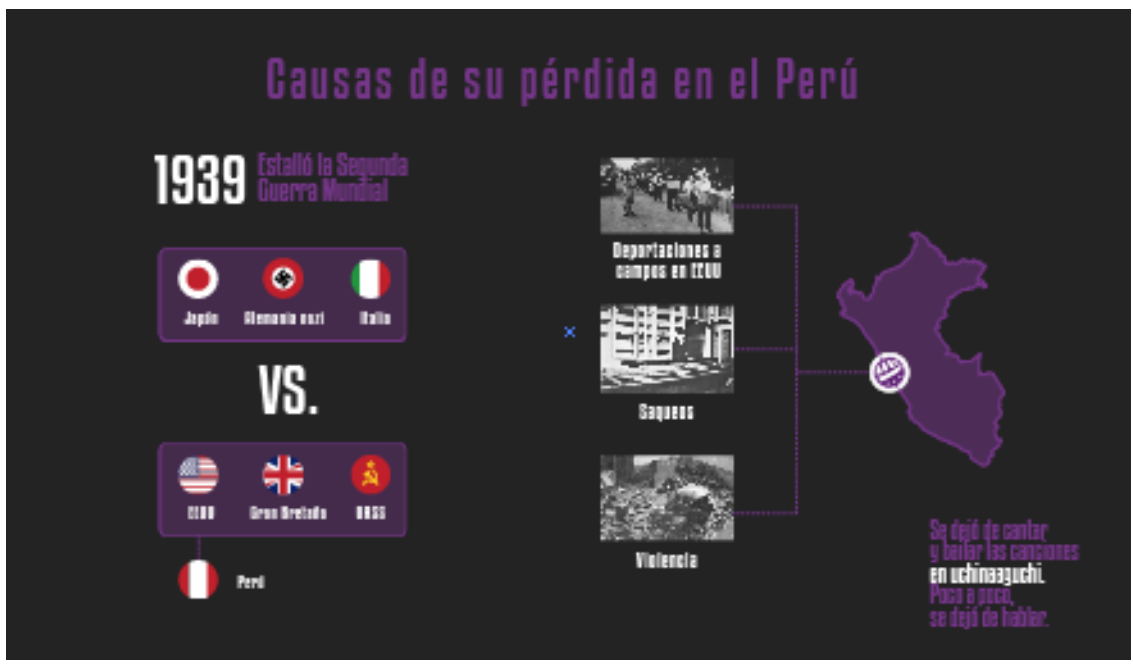

Imagen 8. Causas de su pérdida en el Perú, infografía final de la categoría "por qué"

Por último, la tercera categoría (que responde a “cómo”), se relaciona con el color celeste, pues éste expresa paz y tranquilidad. Esto puede ayudar en el sentido de que ante una amenaza de extinción, el color puede ayudar a dar esa calma que se necesita. 


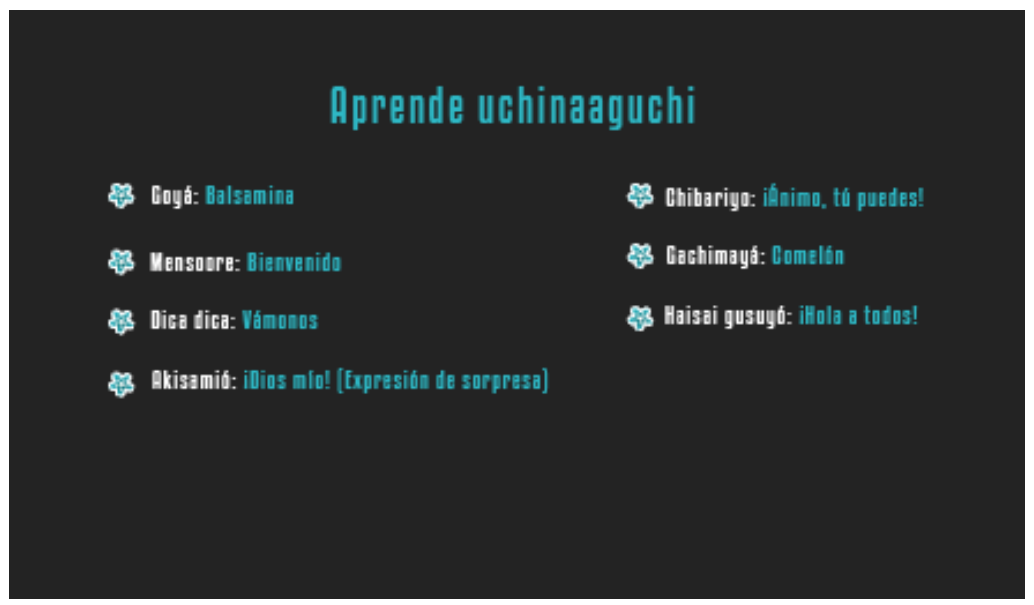

Imagen 9. Aprende uchinaaguchi, infografía final de la categoría "cómo" Finalmente se ha procedido en el diseño de información. Todos los detalles se pueden encontrar en el archivo "Pieza gráfica 2: Aplicación de la Fórmula para utilizar Diseño de información en un documental.” (adjunto).

\section{Evaluación de pares}

En un inicio solo se habían seleccionado los criterios de categorización de la información por similitud o asociación, pero Sanjinez mencionó la posibilidad de que las categorías puedan responder a preguntas importantes, como se suele trabajar en trabajos infográficos. Esto permitió tener un panorama más comunicacional, que permita que la información se pueda agrupar con un sentido que ayude a retener los datos de modo organizado.

Al inicio se quiso crear una infografía muy colorida y alineada a la línea gráfica okinawense (pues el diseño bingata es muy vistoso y llamativo), pero Oshiro comentó que dentro del video esto no sería lo más adecuado, ya que estos elementos se volverían distractores. En ese sentido sugirió que haya un fondo básico, y que sólo algún elemento ayude a relacionar con la cultura. En este sentido, todo lo demás será muy sencillo y permitirá que sea fácil de captar y entender. Por ello, se decidió realizar como diferencia de cada categoría únicamente el color. 
Por su parte, Álvarez sugirió poder dar más importancia a las formas, también extraídas del diseño bingata. Mencionó que se podría hacer una especie de transiciones con estos elementos para crear conciencia de que no son arbitrarios, sino que representan la cultura. Sin embargo, parte de la propuesta es utilizarlos en diferentes momentos del documental (como en la careta, o etiquetas de nombres).

En todo caso, los tres evaluadores estuvieron de acuerdo con la propuesta, considerándola creativa e innovador. Además la vieron práctica y que permite que el mensaje pueda ir en rescate de la lengua.

El trabajo ha mutado y pasado por diferentes validaciones para llegar a los que es hoy, una fórmula que podríamos aplicar a cualquier documental y que sea comprensible, y así lograr que el objetivo de la comunicación se vea reforzado. 


\section{Conclusiones}

Al realizar este trabajo, se puede concluir que el diseño de información es una herramienta poderosa para crear una mejor recordación en los mensajes en los documentales. Se ha visto que los emisores en estos productos audiovisuales invierten mucho esfuerzo y tiempo haciendo una investigación profunda y detallada para poder ofrecer datos valiosos y certeros. Sin embargo, al mostrar a información, ésta no se refuerza para poder ser retenida como se debe, comprendiendo que ha sido presentada con una finalidad comunicativa por parte del director.

Estas piezas audiovisuales suelen estar cargadas de muchos datos interesantes que se pueden perder, pero no debe descuidarse que esta información puede aprovecharse de otro modo, como con el método propuesto. Este permite trabajar la información, priorizar lo que se considere y resumirla, de manera que uno pueda tener una infografía. No solo permite que la información no se pierda, sino que con medios adecuados se puede pensar en oportunidades para difundir la información fuera del medio audiovisual (como con los resúmenes infográficos).

Asimismo, una de los temas que podemos concluir es que existe una carencia de estudios académicos en el rubro de diseño de información en lo audiovisual. Podemos encontrar textos sobre el diseño gráfico en el cine (la utilización en los créditos, o motion graphics, etc.) pero en este tema en específico, los estudios son limitados y es por eso que podríamos considerar esta estrategia como innovadora y de mucha utilidad para futuras investigaciones y para un uso sobre esto.

En el caso del diseño de información aplicado a lo audiovisual, no podemos olvidar que es distinta la aplicación que se da en medios impresos y en video. Existen dimensiones como el espacio, el tiempo, el apoyo sonoro, etc. que son sustancialmente distintos y que son necesarias conocer mejor para poder definir los modos más óptimos de implementación del 
diseño de información en lo audiovisual. Es interesante también encontrar que en el diseño en video, es el diseño es que se mueve, mientras que la línea de mirada cambia en el impreso, pues es el ojo el que está en movimiento. Ante esto también importante tener en cuenta la fuerza que deben tener los elementos para llamar la atención.

Por último, en relación a los estudios que giran en torno a la lengua uchinaaguchi, se puede decir que también hay pocas investigaciones, y mucho menos material audiovisual en nuestro idioma que permita difundir, proteger y enseñar el idioma. Es necesario poder despertar el interés por parte del público objetivo para poder mostrar iniciativas que permitan concoer más de cerca la realidad y también al idioma en sí. 


\section{Recomendaciones}

Por último, al tratarse de un tema poco abordado, es importante ir construyendo entendiendo cómo el diseño de información impreso es distinto al que aparece en video. Para ello, es fundamental poder seguir profundizándose en las cualidades y deficiencias de cada uno de ellos a la hora de estar juntos, para poder encontrar criterios suficientes que permitan tener mayor efectividad.

Asimismo, en las redes sociales se están utilizando cada vez más las infografías y los videos, por lo que es un buen momento para seguir indagando en nuevos métodos para crear piezas de diseño de información que se fusione con video y así seguir aportando a la creación de más material útil.

Por último, con respecto al idioma, considero que si bien es cierto no hay casi ninguna iniciativa en nuestra lengua sobre el uchinaaguchi, debería ser la Prefectura de Okinawa la que se dedique a traducir o a implementar proyectos dirigidos a las comunidades hispanohablantes, con el fin de que este idioma siga manteniéndose vivo entre los descendientes de okinawenses en el mundo. 


\section{Referencias Bibliográficas}

- Arnheim, R. (2006). Arte y percepción visual. Madrid: Alianza forma.

- Azoulay, A. (Agosto, 2019). Mensaje de Audrey Azoulay, Directora General de la UNESCO en ocasión del Día Internacional de los Pueblos Indígenas del Mundo. Recuperado de: https://unesdoc.unesco.org/ark:/48223/pf0000369700.locale=en

- Baer, K. (2010). Information design wordbook. Massachusetts. Rockport.

- Beccaria, G. (2016). Lengua materna. Cuadernos de Filología Italiana, 23, 277-288

- Breschand, J. (2004) . El Documental. La otra cara del cine. Barcelona. Paidós.

- Bringhurst, R. (2008). Los elementos del estilo tipográfico. México: Fondo de Cultura Económica.

- Calderón, B. (2014). Lengua materna y el proceso de iniciación de lecto-escritura (estudio realizado en primero primaria en la Escuela Oficial Urbana Mixta Joselita Allen). Universidad Rafael Landívar, Quetzaltenango.

- Chao-Ming, Y. \& Tzu-Fan, H. (2015). Applying Semiotic Theories to Graphic Design Education: An Empirical Study on Poster Design Teaching.International Education Studies. 8 (12). Recuperado de: https://files.eric.ed.gov/fulltext/EJ1083918.pdf

- Colston, V. (2019). Graphic Design: A Practical Guide for Librarians. Maryland: Rowman \& Littlefield.

- Costa, J. (2007). Diseñar para los ojos. Barcelona: Costa Punto Com Editor.

- Cross, N. (1984). Developments in Design Methodology. Chichester: John Wiley \& Sons Ltd..

- Crystal, D. (1999a). Language Death. Entrevista con Jill Kitson - [Lingua franca (Australian Broadcasting Corporation)]. Recuperado de: https://www.abc.net.au/radionational/programs/archived/linguafranca/languagedeath/3472674\#transcript

- Crystal, D. (20 de noviembre de 1999) Millennium briefing: The death of language. Prospect. Recuperado de: https://www.prospectmagazine.co.uk/magazine/millenniumbriefingthedeathoflanguage

- Crystal, D. (2000). Language Death. Cambridge: Cambridge University Press

- Curry, S., Hijirida, K. \& Serafim, L.(2009). Documenting, teaching, and revitalizing Uchinaa-guchi: the future of the Okinawan language. En Researchgate, recuperado de: https://www.researchgate.net/publication/29740102_Documenting teaching and_revitalizing_Uchinaa -guchi the future of the Okinawan language

- Dalley, T. (1980). Guía completa de Ilustración y diseño. Madrid: Hermann Blume Ediciones. 
- Deltell, L. (2006). El documental de ficción: entretenimiento y manifiesto. En: Rodriguez, I. (Ed.). La ética y el derecho en la producción y el consumo del entretenimiento (p. 183-199). Valencia: Fundación Coso para el Desarrollo de la Comunicación y la Sociedad.

- Eberhard, D.,Simons, G. \& Fennig, C. (eds.). (2019). Ethnologue: Languages of the World. (22da ed.). Dallas: SIL International. Recuperado de: http://www.ethnologue.com

- Eco, U. (2000). Tratado de Semiótica General. Barcelona: Editorial Lumen. Recuperado de: http://mastor.cl/blog/wp-content/uploads/2015/08/ECO-Tratado-de-Semi\%C3\%B3tica-General.pdf

- Ferguson, Ch. (1968) Language Develpment. En: Ferguson, Ch. \& Huebner, T. (Ed). Sociolinguistic Perspectives: papers on language in society, 1959-1994 (pp. 40-47). New York: Oxford University Press.

- Fishman, J. (2001). Can Threatened Languages be Saved?: Reversing Language Shift, Revisited: a 21st Century Perspective. Nueva York: Multilingual Matters.

- Galdames, V., Walqui, A \& Gustafson, B. (2006). Enseñanza de Lengua indígena como Lengua Materna (1ra ed.). Bonn: InWent.

- Gamonal-Arroyo, R., \& García-García, F. (2015). La capacidad discursiva del diseño gráfico. Arte, Individuo y Sociedad, 27(1), 41.

- Goebel, M. \& Fotos, S. (2001). Studies in Japanese Bilingualism. Nueva York: Multilingual Matters.

- Gonzalez (s.f.). Metodología del diseño. Universidad de Londres. Recuperado de: https://www.guao.org/sites/default/files/biblioteca/Metodologia\%20del\%20Dise\%C3\%B1o.pdf

- Grier, Ch. (24 de agosto de 2018). How musicians are keeping endangered languages alive. Toronto now. Recuperado de: https://nowtoronto.com/music/features/music-endangered-languages/

- Hartnett, K. (7 de octubre de 2013). Using art to preserve an endangered language. Boston.com. Recuperado de: http://archive.boston.com/bostonglobe/ideas/brainiac/2013/10/hamid kachmar.html

- Hein, L. \& Selden, M. (Eds.). (2003). Islands of discontent. Maryland: Rowman \& Littlefield Publishers, Inc.

- Heinrich, P. \& Ishihara M. (2017). Ryukyuan languages in Japan. En Seals, C. \& Shah, Sh. (Eds), Heritage Language Policies around the world (pp.165-184). Londres: Routledge.

- Heinrich, P., Bairon, F. \& Brenzinger, M. (2009). The Ryukyus and the New, but endangered, langagues of Japan. The Asia-Pacific Journal. 7(2). Recuperado de: https://apijforg/-PatrickHeinrich/3138/article.html

- Herrera, M.A. (11 de noviembre de 2010). Investigación y diseño: reflexiones y consideraciones con respecto al estado de la investigación actual en diseño. No solo usabilidad. Recuperado de: http://www.nosolousabilidad.com/articulos/investigacion_diseno.htm 
- Hijirida, K., \& Oshiro, T. (2010). Aloha Uchinaaguchi. Inicio. Recuperado de: http://eall.hawaii.edu/alohaokinawan/index.html

- Ishihara, M., Miyahira, K. van der Lubbe, G. \& Heinrich, P. (2019). Ryukyuan sociolinguistics. En Heinrich, P. \& Ohara, Y. (Eds.). Routledge Handbook of Japanese Sociolinguistics. Londres: Routledge

- Jacobson, R. (1999). Information Design. Cambridge: The MIT Press

- Katz, J. (2012). Designing Information. Human factors and common sense in information design. New Jersey: John Wiley \& Sons, Inc.

- Landa, R. (2017). Graphic Design Solutions (sexta edición). Boston: Cengage.

- Lipton, R (2007). The Practical Guide to Information Design. New Jersey: John Wiley \& Sons, Inc.

- Lupton, E., \& Phillips, J. C. (2016). Diseño gráfico: nuevos fundamentos.

- Maffi, L. (2002). Endangered languages, endangered knowledge. International Social Science Journal. Recuperado de: https://www.academia.edu/27506291/Endangered languages endangered knowledge

- Marcos-Marin, F. (2020). Humanidades Hispánicas. Nueva York: Peter Lang. Recuperado de: https://www.researchgate.net/publication/338842908_Semiotica_y_Semiologia

- Marret, A. \& Barwick, L. (Diciembre de 2002). Endangered songs and endangered languages. Conferencia presentada en Seventh conference of the Foundation for Endangered Languages "Maintaining the Links: Language, Identity and the Land". Recuperado el 2 de setiembre de 2019, de https://www.researchgate.net/publication/216019830 Endangered Songs and Endangered Languages

- Mie, A. (19 de mayo de 2012). Okinawans push to preserve unique language. Japan Times. Recuperado de: https://www.japantimes.co.jp/news/2012/05/19/national/okinawans-push-to-preserveunique-language/\#.XW1DL5NKiRt

- Mijksenaar, P. (1997). An Introduction to Information Design. Rotterdam, 010 Publishers.

- Ministerio de Educación (2012). Actas del Congreso Iberoamericano de las Lenguas en la educación. Las lenguas en la educación: cine, literatura, redes sociales y nuevas tecnologías. Secretaría general técnica. Madrid.

- Moreno, C. (2009). El diseño gráfico en materiales didácticos. Bruselas: Centre d’Etudes Sociales sur Améirque Latine (CESAL).

- Moseley, C. (ed.). 2010. Atlas de las lenguas del mundo en peligro (3ra ed.).París: UNESCO. Recuperado de: http://www.unesco.org/culture/en/endangeredlanguages/atlas

- Nichols, B. (1997). La representación de la realidad. Barcelona: Ediciones Paidós.

- Perez, N. (2011). Significación plástica de la tipografía desde la mirada de la semiótica visual. Revista Kepes. 8(7), pp. 269-288. 
- Perez, N. (2010). Apuntes sobre semiótica en tipografía. Revista S. Bucaramanaga: Universidad Industrial de Santander. Vol 4, pp. 11-27.

- Petterson, R (2002). Information design. An introduction. Philadelphia: John Benjamins Publishing Company.

- Pratt, R. (s.f.). Semiotics and Professional Graphic Design. Academia.edu. Recuperado de: https://www.academia.edu/494437/Semiotics_and_Professional_Graphic_Design

- Rabiger, M. (1992). Directing the Documentary. Boston: Focal Press.

- Reina, A. (2011, 14 de octubre). El diseño gráfico en la activación motivacional de las audiencias [versión electrónica]. Entrearte, 6, 158-132.

- Sakihara, Mitsugu (2006). Okinawan-English wordbook : a short lexicon of the Okinawan language with English definitions and Japanese cognates. Honolulu: University of Hawai'i Press.

- Serrano, S. (1999). La Lingüística su historia y su desarrollo (3ra ed.). Barcelona: Montesinos Editor.

- Sherin, A. (2018). Introduction to Graphic Design to Thinking, Process \& Style. Londres: Bloomsbury.

- Shimabukuro, J. (2014, 14 de mayo). Learn basic uchinaaguchi [Liuchiuan]. Recuperado de: https://liuchiuan.com/2014/05/12/learn-basic-uchinaaguchi/

- Strochlic, N. (16 de abril de 2018). The race to save the World's Disappearing languages. National Geographic. Recuperado de: https://www.nationalgeographic.com/news/2018/04/saving-dyingdisappearing-languages-wikitongues-culture/

- TEDxTalk (1 de junio de 2014). Saving endangered languages through music: Susanna Zaraysky at TEDxSantaCruz. [Archivo de video]. Recuperado de: https://www.youtube.com/watch?v=dUdCToPPK5A

- Tejada, J. \& Valencia, A. (2008). Demasiada lluvia sobre el Paraíso (Tesis Licenciatura). Universidad de las Américas Puebla, Puebla.

- Trombetti, A. (1905). L'Unità d'origine del linguaggio. Boloña: Beltrami.

- UNESCO. (2003). Vitalidad y peligro de desaparición de las lenguas. Paris: UNESCO

- UNESCO. (2014). Atlas interactivo UNESCO de las lenguas del mundo en peligro [Unesco.org]. Recuperado de: http://www.unesco.org/languages-atlas/index.php

- United Nations Economic and Social Council (ECOSOC). (2018). Plan de acción para organizar el Año Internacional de las Lenguas Indígenas 2019. (Sesión 17). Nueva York: UNESCO

- Wikitongues. (sin fecha). Inicio. Recuperado de: https://wikitongues.org/

- Wotjak, G. (2006). Las lenguas, ventanas que dan al mundo (1ra ed.). Salamanca: Ediciones Universidad de Salamanca. 


\section{Anexos}

\section{Anexo 1}

\section{Entrevista a Jorge Igei Ikehara \\ Director del Museo de Inmigración japonesa al Perú}

- ¿Podría presentarse, por favor?

Hola, mi nombre es Jorge Igei, soy director del Museo de Inmigración Japonesa al Perú "Carlos Chiyoteru Hiraoka".

\section{- ¿Puede contarnos un poco sobre la migración japonesa al Perú, por favor?}

Este año se cumple 120 años del inicio de la migración japonesa al Perú que se inició en 1899 con la llegada de 790 inmigrantes a trabajar en las haciendas azucareras de la costa peruana. Hasta 1923 los inmigrantes japoneses llegaron bajo la modalidad de contrato y llegaron más de 18 mil japoneses en esos 24 años. A partir de ahí, llegaron bajo la modalidad de llamado: los japoneses que residían aquí podían llamar a sus familiares en Japón para venir a trabajar en el Perú y ayudarles en sus pequeños negocios que tenían.

\section{- ¿Y la inmigración okinawense?}

La inmigración okinawense se inició en 1906 con la llegada de 36 okinawenses a nuestro país y se fueron a las haciendas azucareras al igual que los inmigrantes de las demás prefecturas japonesas.

Los okinawenses que llegaron al Perú fueron a las haciendas azucareras del norte del País, sobre todo en la parte del norte del departamento de Ancash así como el departamento de La Libertad. La inmigración okinawense al Perú llegó a ser la más numerosa abarcando casi el $50 \%$ de la totalidad de la inmigración japonesa al Perú

Los okinawenses y descendientes de okinawenses, trabajaron en diversas haciendas inicialmente y luego fueron creando sus propios negocios, y a raíz de ello, se fueron incorporando a la sociedad peruana y también formando familias.

Okinawa se incorporó a Japón recién en 1872 y tenían costumbres, idiomas muy diferentes al Japón de esa época. Es por eso que su convivencia con los japoneses de las islas principales no eran del todo adecuada y también los okinawenses comenzaron a convivir entre ellos.

Debido a la cantidad numerosa que tenían, podían crear su propio círculo social, es por eso que muchas veces se desarrollaban de forma paralela. Sin embargo en las épocas difíciles que se produjo en el Perú a partir de 1930 contra los japoneses.

A partir de 1930 la situación de los japoneses fue cada vez más difícil pero se empeoró a raíz de que Japón bombardeó Pearl Harbor en Hawai y se inició la guerra nipo americana. Durante la Segunda Guerra Mundial, la situación de los japoneses fue bastante incierta porque de los 2200 japoneses que fueron deportados de latinoamérica hacia Estados Unidos, hacia los campos de concentración, 1771 fueron provenientes del Perú, japoneses que radicaban en el Perú hacia Estados Unidos. Eso originó también la persecución mediante una lista negra, así como la clausura de las instituciones, colegios y prohibiendo incluso el hablar en idioma japonés y eso ocasionó que los japoneses guardaran un perfil bajo tratando de 
adentrarse entre la población. Muchos japoneses se refugiaron en las provincias de la sierra o de la selva; también recibieron el apoyo de la población peruana y eso les permitió sobrevivir la Segunda Guerra Mundial.

A raíz del inicio de la guerra entre Japón y Estados Unidos, el Perú fue aliado de Estados Unidos, se alinea con ese país, y hace una serie de actos como la clausura de colegios, de instituciones, periódicos y prohibiendo incluso que se hable en idioma japonés, así como las reuniones de dos o más personas. Incluso no se podía escuchar la radio de onda corta porque era parte de la información que podían recibir de Japón.

Al terminar la Segunda Guerra Mundial, los japoneses que inicialmente habían venido al Perú en su mayoría, para juntar un poco de dinero y luego retornar a su país, cambiaron totalmente de actitud, decidieron quedarse en el Perú porque era un país al que ya se habían acostumbrado, a pesar de algunos malos momentos vividos, es donde sus hijos habían nacido y también vieron que en Japón no había mayor futuro porque el país había sido devastado por la guerra. Es así como deciden quedarse en el Perú, que sus hijos se conviertan en buenos estudiantes y en el futuro en buenos ciudadanos y es que ante la clausura de los colegios japoneses, van yendo a estudiar a los colegios nacionales y posteriormente a las universidades nacionales también, formándose a partir de 1960 una generación de profesionales nisei que comenzaron a destacar en diferentes ramas. Como decidieron quedarse en Perú vieron que tampoco era necesario seguir la enseñanza del idioma japonés, es por eso que todos, incluso los japoneses comenzaron hablar con sus hijos en un castellano muchas veces rudimentario pero que les permitía una comunicación con sus hijos.

\section{- ¿Cómo es el uso del idioma uchinaguchi en las familias Okinawenses?}

El uchinaaguchi, el idioma de Okinawa, estaba difundido entre los inmigrantes japonés y durante la época de la pre-guerra estaba bastante difundido también entre los hijos. Era un idioma que se practicaba en familia o dentro de la comunidad okinawense en el Perú; sin embargo era un idioma difícil, o mejor dicho, imposible para los que no eran okinawenses conocer el significado de ese idioma.

\section{- ¿Cómo es su contacto con el uchinaaguchi?}

El uchinaaguchi, idioma de los okinawenses, se solía hablar entre los mayores y uno de tanto escuchar hablar a ellos comenzó a conocer ese idioma, valga la redundancia, pero no podía hablarlo porque es un idioma un poco difícil de pronunciar. Sin embargo, la música, los bailes de los okinawenses están basados en ese idioma, en el uchinaaguchi. Es por eso que a raíz de la prohibición del idioma japonés en el Perú, también la lengua de los okinawenses se fue perdiendo. A mediados de los años 80, el puente que se tendió entre Okinawa y sudamérica, con la recepción de jóvenes descendientes okinawenses, algunos pueblos de Okinawa comenzaron a recibir jóvenes descendientes de Okinawa de sudamérica. A su retorno estos jóvenes comenzaron a difundir la cultura okinawense que habían aprendido durante su estadía en Okinawa y, entre ellos, también poco a poco el idioma. Es así que a partir de la época de los 90 prácticamente se crean nuevos movimientos culturales de okinawenses propiciados por estos jóvenes, sobre todo con la música, las danzas, el taiko (tambor okinawense) y eso ha permitido también que los jóvenes sean los precursores de esta nueva cultura okinawense en nuestro país. Por otro lado también la música de los okinawenses ha cambiado: durante mi niñez escuchaba música que era un poco triste, melancólica, que realmente no nos gustaba. Cuando tuvimos la oportunidad de conocer 
Okinawa, descubrimos otra música, más joven, más melódica, que llenó nuestro vacío, digámoslo así, del contacto con la cultura okinawense. Eso nos permitió acercarnos a sus canciones, a sus danzas, a sus bailes.

\section{- ¿Cuál es la situación del uchinaaguchi entre sus descendientes?}

El uchinaaguchi prácticamente no se habla, más que algunos saludos; no es un idioma que se está enseñando metódicamente. Creo que tampoco hay mucho interés en aprenderlos, salvo aprender unas canciones que se cantan en ese idioma. Por otro lado no tenemos más que unos cuantos profesores que saben ese idioma y tampoco creo que se da la fuerza necesaria como para aprenderlo.

\section{- Actualmente, ¿las personas mayores lo hablan?}

En estos momentos las personas que están bordeando los 80 años, osea los que han tenido su niñez durante la época de la Segunda Guerra Mundial pueden entender un poco más el idioma okinawense pero prácticamente los menores de esa edad es un poco difícil que puedan entender fácilmente, sobretodo los jóvenes de la tercera o cuarta generación.

\section{- ¿Por qué consideramos que existe esta pérdida?}

Creo que los isei okinawenses tampoco propiciaron el aprendizaje de la esta lengua porque ya había la prohibición del idioma japonés. Entonces para un peruano era lo mismo un idioma japonés o el idioma okinawense, entonces igualito los mayores no propiciaron esa práctica de esa lengua entre los jóvenes.

\section{- ¿Qué supondría la pérdida del uchinaaguchi para los descendientes de Okinawa} del Perú?

Yo creo que toda pérdida cultural, es una gran pérdida realmente. Sin embargo, debemos poner esfuerzos si es que realmente estamos interesados en rescatar esa forma cultural como es el idioma okinawense. Creo también que por parte de Okinawa deberían ser los principales interesados en que en nuestro medio no se pierda esta cultura y deberían, a su vez, propiciar la difusión del idioma mediante cursos o canciones. Difundir la cultura okinawense mediante el uchinaaguchi.

Bueno, para mantener o rescatar el idioma okinawense en nuestro medio creo que la misma prefectura de Okinawa debería ser precursora de esta iniciativa enviando profesores del idioma uchinaaguchi, enviando números culturales en que se utilice dicho idioma y, a su vez, propiciar de alguna manera la difusión en este medio.

- ¿Qué podrías decirle a las generaciones de okinawenses del Perú sobre este idioma o sobre la cultura okinawense y sus raíces?

Yo creo que una persona aprende a valorarse más cuando sabe de dónde proviene y realmente para mí haber conocido Okinawa como ex becario a nivel de "shi-cho-son" fue para mí una magnífica oportunidad para conocer mis raíces, para conocer el espíritu okinawense, de solidaridad, de ayuda mutua y sobre todo que se dice que es el pueblo más acogedor del mundo y realmente uno tiene una gran satisfacción de ser un peruano con raíces okinawenses. 


\section{- ¿Cómo ha sido el proceso de desaparición del idioma en Okinawa?}

Okinawa luego de terminar la guerra fue ocupada por las fuerzas norteamericanas de 1945 hasta 1972 en que se produjo la devolución de Okinawa hacia el Japón. En ese lapso, los norteamericanos prohibieron la difusión del idioma okinawense, la enseñanza e incluso su práctica, solo lo practicaban de forma clandestina, por decir, las personas mayores que habían aprendido durante su niñez esa lengua. Es por eso que los jóvenes que nacieron durante la dominación norteamericana prácticamente no aprendieron el idioma okinawense.

\section{- ¿Cuéntanos sobre la experiencia en tu casa sobre el uso del idioma?}

Mi padre y mi madre ambos tenían raíces okinawenses. Mi padre nació en Okinawa y mi madre era una nisei hawaiana que fue a Okinawa a estudiar su primaria y secundaria, y luego retorno a Hawai. Entre ellos hablaban en idioma okinawense pero muchas veces tenían que contactarse con otras personas japonesas que normalmente utilizan el idioma japonés o utilizaban el idioma okinawense cuando había una reunión de gente de la misma comunidad okinawense. Por otro lado, también cada pueblo okinawense tiene una forma diferente de hablar su propio idioma, así que a veces entre ellos también era un poco difícil entenderse.

\section{Anexo 2}

Resultados de las encuestas a la pregunta:

\begin{tabular}{|l|}
\hline ¿Por qué los jóvenes no se interesarían por aprender este idioma en el Perú? \\
\hline No saben que existe \\
\hline No hay donde estudiar \\
\hline Por tiempo. Por no sentir la necesidad. \\
\hline No hay profesores \\
\hline $\begin{array}{l}\text { Falta de difusión, cursos, actividades de parte de AOP e instituciones. En general la } \\
\text { misma institución no le da la misma importancia a la lengua y a la historia. Más se } \\
\text { enfocan en cultura como baile y música. En el país tampoco se le da importancia a las } \\
\text { lenguas, no se valora como parte de la cultura. }\end{array}$ \\
\hline $\begin{array}{l}\text { Porque las culturas costumbres se van renovando. Porque no tenemos tiempo para } \\
\text { cultivar cultura, vivimos muy apresurados con el tiempo } \\
\text { (trabajo,estudios,familia,amigos)Los jóvenes nikkei actualmente estamos más } \\
\text { insertados en la sociedad peruana màs que los Issei nisei }\end{array}$ \\
\hline $\begin{array}{l}\text { A mi me parece interesante pero de acuerdo a la respuesta tal vez porque no es muy } \\
\text { usado y no habría con quien conversar }\end{array}$ \\
\hline $\begin{array}{l}\text { Quizas por que no lo practicamos lo suficiente, y por esa razon algunos jovenes no } \\
\text { conocen el uchinaguchi }\end{array}$ \\
\hline Porque no les suma en su CV y no se sienten identificados con sus raíces uchinanchu \\
\hline Porque no hay un círculo en donde utilizarlo \\
\hline
\end{tabular}


Si no les interesa el quechua mucho menos uchinaguchi

Yo creo que el problema raíz es que no hay mucho conocimiento general sobre la lengua y sobre su enseñanza mas que la falta de deseo de aprendizaje.

Porque no tienen interes, desde pequeños no les incuncan el idioma

Pocas oportunidades que abre fuera de Okinawa. Incluso en Okinawa mismo

No hay mucha gente con quien practicar.

Primero tendrían que interesarse por aprender japonés

Porque podrían percibir que no tienen donde aplicarlo, solo se que lo enseñan en el AOP y es un lugar que me queda lejos. . Por otro lado, quizás prioricen aprender el japonés que pueden usarlo más que el uchinaguchi.

Creo que no lo toman como algo necesario o que les vaya a servir más adelante

Por lo poco que se usa

Yo considero que sí hay interés, sin embargo, parece que aún no hemos hallado la dinámica adecuada para enseñarlo. Por otro lado, en el caso de las personas

desinteresadas, creo que sería porque no le encuentran utilidad.

Por lo complicado/poco práctico

Puede ser que no sea de su agrado, les paresca extraño

No hay alguien que domine el uchinaguchi en el Perú y no se utiliza mucho en el okinawa actual.

Porque no es practico y no se usa en la vida cotidiana

"no es muy necesaria" como inglés

Porque ya no de usa, ni los mismos pobladores de okinawa lo manejan, almenos eso fue lo que me dijeron cuando estube en la beca. Es como aca el quechua

Flojera? Desconocimiento tambien

Creo que podría ser porque no es un idioma muy practicado actualmente, no es muy

práctico aprenderlo

Puede no parecerles útil o interesante

Porque no es de uso común o práctico (es difícil encontrar con quién hablar en uchinaguchi)

Generalizando: por la gobalización; no hay gran población que lo emplearía y si lo hubiese sería un círculo pequeño en comparación a otras lenguas indígenas

No hay mucha oportunidad para practicarlo como otros idiomas 


\section{Anexo 3 \\ Selección de los textos desde el Guión del documental}

\section{INT. PASILLO DE AUDITORIO - NOCHE}

KENJI, de 33 años, está sentado, firmando autógrafos en la mesa donde venden sus discos luego de su concierto. Las personas se toman foto con él.

\section{INT. AUDITORIO - NOCHE}

Se ve a Kenji cantando "Haisai gusuyo" en su concierto.

\section{INT. SALA - DÍA}

$$
\text { ENTREVISTADO } 1
$$

Hola. Soy nikkei de 3ra generación. La verdad que no se nada de uchinaaguchi.

$$
\text { ENTREVISTADO } 2
$$

Hola. Soy nikkei de 3ra generación. No sé mucho sobre el uchinaaguchi

\section{ENTREVISTADO 3}

Para el año 2100 se calcula que se perderán 3000 idiomas y, si no se hace nada, una de ellas será el uchinaaguchi

\section{(Careta) - "Uchinaaguchi: el idioma de oji y oba" (título)}

Me cuesta mucho pensarlo, y en general saber que hace menos de 5 años en realidad no me importaba. Hay cosas valiosas a nuestro alrededor que muchas veces no valoramos y dejamos que poco a poco mueran. Ese era yo, un nikkei de tercera generación que iba a hacer que la cuarta no viva todo lo que yo he vivido, es por eso que hago esto para decirte:

Umarejima nu kutuba washinnee, kunin washun (si olvidas la lengua de tu tierra natal, olvidarás también a tu tierra natal)

\section{EXT. AOP - DÍA}

Kenji caminando en el AOP, mostrando la imagen de su abuelito en un mural

\section{VOZ EN OFF}

Este es mi abuelito, mi oji. Su nombre era Ginyu Igei. Las cosas se ponían feas en Japón y encontró en la migración una oportunidad y salió en búsqueda de un futuro mejor en Perú. El vivió hasta que yo 
tuve 18 años, aprendió a hablar español aquí (me imagino cuánto le habrá costado), me imagino el sentimiento de no poder comunicarse y por qué no la impotencia. Me imagino cuántas veces se habrá gritado a sí mismo: "Chibariyo" (Vamos, tu puedes). Mi oji no solo dejó su tierra sino que poco a poco también su lengua.

Mi papá me cuenta que los escuchaba hablar a él y a mi oba (abuela) en uchinaaguchi, pero yo la verdad no lo recuerdo bien. Pero soy consciente que en mi casa no solo se usa el español para referirnos a las cosas.

Mi oji era alguien especial, un luchador que buscaba crear un puente entre su tierra natal y la tierra que ahora lo acogía. El y los primeros migrantes se esforzaron mucho para poder mantener sus costumbres, tenían actividades y eventos donde bailaban, cantaban, y continuaban con algunas de sus tradiciones. Además, crearon colegios donde se seguía el sistema de enseñanza japonés pues muchos de ellos tenían la ilusión de volver. Todo andaba bien hasta que en 1939 estalló la Segunda Guerra Mundial. Japón era aliado de Alemania e Italia, quienes eran enemigos de Estados Unidos. Por su parte, Perú hizo un pacto con el país americano, asi que los migrantes japoneses y su descendencia empezaron a ser perseguidos, hubieron saqueos, deportaciones a campos de concentración en EEUU, hubo violencia contra la comunidad como si nosotros tuviésemos la culpa. No solo se perdieron muchas cosas materiales, sino que también la herencia cultural se estancó. Se dejó de cantar y bailar las canciones en uchinaaguchi. Poco a poco, se dejó de hablar.

INT. CASA. DÍA.

JORGE IGEI

La migración okinawense fue 1906, cuando llegó el primer grupo de okinawenses para buscar nuevos horizontes. Poco a poco llegaron más, hasta ser el grupo más numeroso de japoneses en el Perú.

El interés se fue perdiendo durante la guerra, en que el gobierno peruano prohibió la enseñanza del idioma japonés. Esto hizo que los japoneses no se comunicaran ni en japonés, ni en ningún dialecto. En el caso del uchinaaguchi se fue perdiendo porque no era un idioma que se enseñara sino en el que se hablaba con familias y amigos. 


\section{EXT. AOP - DÍA}

Kenji caminando en el AOP

\section{VOZ EN OFF}

En el 2015, fui de beca a Ginoza, el lugar donde mi oji nació. Podría decir que ahí fue donde me redescubrí, encontré mis raíces. Muchas de las cosas no me parecían nuevas, sino que me eran muy familiares.

Una de las cosas que más caracteriza Okinawa es el "Okaeri", bienvenido de vuelta a casa. No puedo describir la emoción que sentí cuando llegué. El "Icharibachode" (cuando nos conocemos somos hermanos) era muy palpable y real y sé que así como yo, todos los que han vivido esa experiencia de volver a sus raíces, lo han sentido también.

Aparecen tomas en Okinawa durante la beca de Kenji

(CONT.)

Durante la beca descubrí que habían algunas expresiones que usaba desde niño, que pensaba que eran en japonés, pero en realidad estaban en uchinaaguchi. "Kwatchi sabira", "Goyá","Dica dica", "Akisamio","Gachimayá"... Fue una experiencia consciente y un descubrir sorprendente para mí.

Cuando uno va de beca, a todos los becarios nos enseñan como mínimo la presentación en esa lengua. Y como en varias ocasiones nos hacían presentarnos ante diferentes personas, fue algo que aprendí muy bien. "Wanne Igei Kenji yaibin".

Estando en Okinawa, fui descubriendo mi identidad y mis raíces de un modo particular y todo ello lo traduje en una canción que compuse. Esta narra lo que fui encontrando y me faltaba un cierre para culminar el coro. Y pensé, ¿por qué no decir "soy okinawense"? Y cómo había aprendido mi presentación en uchinaaguchi, simplemente reemplacé mi nombre por uchinanchu. Y me di cuenta que esta oración resumía completamente lo que quería expresar.

Lo increíble es que la canción no era un reflejo solo de mi identidad, sino que muchas más personas pudieron cantar conmigo, que somos okinaweneses. 
Aquí en Perú, una vez tuve la oportunidad de cantar en un programa de televisión. Me pidieron que hable algo en japonés, pero decidí presentarme en uchinaaguchi, pues marcaba mucho mi identidad.

Aparecen tomas de "Los 4 Finalistas"

Haisai gusuyo, chuu uganabira, wanne Igei Kenji yaibin. Yutasarugutu unigee sabira.

INT. SALA - DÍA

\section{KARINA VALLEJOS}

Este sistema de beca es importante porque permite a los jóvenes acercarse a su cultura y parte de ello al uchinaguchi. Nadie puede valorar algo que no conoce y al vivir esta experiencia empiezan a valorarlos.

Existen diferentes tipos de beca para ir a Okinawa. Hay de la prefectura de Okinawa (beca kenpi y Junior Study Tour) y las que ofrecen los mismos municipios (shi cho son).

\section{VOZ EN OFF}

Desde el año 1970, han viajado "cientos" de becarios. Algunos programas son de un mes, otros de 3 meses, otros de 6 y hasta de un año.

\section{INT. SALA - DÍA}

\section{MUNETAKA GANAHA}

Hoy en día, el uchinaaguchi se encuentra en peligro de extinción. Es cierto que en el gobierno de Okinawa hay algunas iniciativas para preservarla, pero aún son insuficientes, los jóvenes no lo hablan.

\section{EXT. AOP - DÍA}

Kenji caminando en el AOP

\section{VOZ EN OFF}

Cuando fui a Okinawa, me di con la sorpresa de que la mayoría de jóvenes no hablaban esta lengua. Allá existe una crisis generacional en el uso del idioma: la población que lo considera como un idioma vivo es mayor de 75 años; aquellos que lo entienden y lo usan poco tienen entre 45 y 75 años, mientras que los menores a 45 usan solo el japonés. 
"Si las comunidades de hablantes y los lingüistas no actúan inmediatamente, todas las lenguas de Okinawa habrán desaparecido para el 2050".

Una vez me dijeron que estando allá aprenda y utilice palabras en uchinaaguchi, y que los mayores se emocionarían de que un joven esté interesado en preservar su lengua. Y así hice. Llené mi libreta de notas digital y fui poniendo en práctica ese consejo. A partir de ahí, el uchinaaguchi se volvió un mundo al que le tomé cariño y fue una herramienta para unirme con Okinawa.

\section{EXT. AOP - DÍA}

Kenji caminando en el AOP, saludando a los jóvenes

\section{VOZ EN OFF}

En el Perú, la mayoría de los jóvenes no conocen esta lengua, no saben palabras, ni tienen un contacto cercano con ellos.

\section{INT. SALA - DÍA}

\section{JORGE IGEI}

En la postguerra, los de segunda generación (los que nacieron antes del inicio de la guerra) podían comunicarse un poco en uchinaaguchi. Por otro lado, los que nacieron después, no lo podían hacer pues todo estaba castellanizado.

Nosotros como nikkeis peruanos no tenemos mayor incentivo en aprender; no tenemos con quién conversarlo y de quién aprender. Si habláramos entre nosotros, lo hablaríamos mal, y eso no sería una buena práctica.

INT. SALA - DÍA

\section{KARINA VALLEJOS}

El uchinaaguchi en nuestro país, yo creo que se está perdiendo lamentablemente. Hay una razón, razón de ir avanzando en generaciones; ya no tenemos de donde aprender; ya no tenemos oji, oba que nos enseñe.

\section{VOZ EN OFF}

Realice unas encuestas con decenas de ex becarios, personas que habían vivido la misma experiencia que yo y me di con grandes sorpresas:

- $75,9 \%$ se siente okinawense 
- 87.5\% conoce menos de 25 palabras

- 62,5\% de becarios dice que estaría interesado en aprender si sabe que está en riesgo

A pesar de que estos resultados, son positivos, no podríamos generalizar ni me atrevería a decir que los que no han tenido la oportunidad de conocer Okinawa responderían de la misma manera. El 71,9\% de los encuestados respondió que aprendieron uchinaaguchi durante la beca.

La realidad es que, como yo antes de ir de beca, la mayoría de los jóvenes no sienten interés por sus raíces y menos por una lengua que no es suya ni que les da ningún beneficio laboral o profesional, y por qué no, ni siquiera una satisfacción personal.

\section{KARINA VALLEJOS}

El acercamiento de los becarios con la lengua de Okinawa es desde que llegan a la isla, cuando ven un cartel que les dice "mensoore" (bienvenido). No todos tienen clases directamente, no todos tienen, pero el acercamiento está en todos lados porque todavía se habla. Es un acercamiento de la vida diaria.

\section{INT. AOP - DÍA}

Kenji caminando en el hall del teatro

\section{VOZ EN OFF}

"Es a través de las canciones, los bailes y las ceremonias que los pueblos indígenas mantienen sus culturas y un sentido de identidad dentro del mundo." Esto también pasa en Perú.

Se ven afiches, videos y fotos de los eventos que se van mencionando.

(CONT.)

Aquí hay muchas actividades artísticas y culturales que permiten mantener los lazos con las raíces. Cada cierto tiempo hay eventos como el Icharibachoode, el Okinawa Matsuri, el Uchiná engeikai

KARINA VALLEJOS

A través de la música es por donde los jóvenes se acercan a Okinawa en primera instancia. 
JORGE IGEI

La música expresa lo que siente el uchinanchu por su tierra; al perder el conocimiento del significado, se pierde el "kimochi".

VOZ EN OFF

En la Prefectura de Okinawa existen iniciativas para cultivar la lengua, pero aquí en Perú esto se ve un poco dificil de lograr, en especial porque no hay quien la enseñe. ¿Se imaginan todo lo que perderíamos si la lengua se llegara a extinguir? No solo hablo de Okinawa, si no también aquí en Perú.

\section{KARINA VALLEJOS}

El uchinaaguchi es parte de la cultura de tus antepasados; perder el uchinaaguchi es perder parte de tu vida. Si se pierde y no lo valoramos, nosotros vamos muriendo, también.

Siendo eso la parte principal, no solo perderíamos la lengua sino el arte, y perderlos no hace que entendamos nuestra historia.

\section{JORGE IGEI}

La pérdida del idioma uchinaaguchi traería un gran vacío por el impacto cultural y social, ya que muchas de las obras artísticas, están en ese idioma.

INT. CASA. NOCHE .

Imágenes sobre lo que se narra

\section{VOZ EN OFF}

Hace unos meses, se quemó el Castillo de Shuri: un emblema para todos los okinawenses y un Patrimonio de la Humanidad según la UNESCO. Representaba la historia, la cultura, el arte... representaba a Okinawa.

A raíz del desastre, han habido varias iniciativas que han buscado obtener fondos para reconstruirlo. En una campaña de crowfunding, que se inició un día después del incendio, se recaudaron a los tres días el doble de la meta (2 millones de dólares). Al terminar la campaña (152 días después) se logró recaudar nueve veces más del objetivo. Además, de esta hubieron varias otras iniciativas en favor de la reconstrucción que mostraron la capacidad y la disposición de los okinawenses para volver a tener su castillo de vuelta. Los uchinanchus han 
demostrado el orgullo por su identidad, por su historia, por sus raíces.

La buena noticia es que el castillo se puede reconstruir. La mala es que es necesario ponerse la mano al corazón para darnos cuenta que así como se hicieron esfuerzos para reconstruir el castillo, deben darse los esfuerzos para recuperar, mientras estemos a tiempo, la lengua de oji y oba. Si de aquí a unos años se extingue, ni por más que tengamos 9 millones de dólares, lograremos revivirla. No se tratará de dinero recaudado, sino de iniciativas, preocupación, enseñanza, utilización y difusión de la lengua. Ahora es cuando. El castillo del uchinaaguchi está en llamas y todas las riquezas que lleva dentro, sean canciones, poemas, libros, bailes, frases, podrían terminar siendo ceniza. Unidos podemos. Chibariyo!

Yo quiero poner mi grano de arena desde la música. Varias de mis canciones tienen frases en uchinaaguchi como "ippe nifee debiru", "nuchidu takara", "icharibachoode", "haisai gusuyo", "wanne uchinanchu yaibin", entre otros. Cada vez que las canto, voy explicando sus significados y me interesa que las personas puedan conocerlas.

Esta vez, desde el diseño, también estoy aportando con este propósito. Comprendí que se me entregó un regalo, y que éste debe ser compartido. Se me ha entregado algo frágil y fácil de romper, de extinguir, que de mi parte merece un cuidado. Si tú, al ver esto, sientes que también tienes un gran regalo cultural, desde lo que tú eres y de tu vida diaria, lo podrás valorar y sobretodo compartir con otros, en memoria de quienes lo usaban a diario. Juntos podemos hacer algo por el uchinaaguchi, el idioma de oji y oba.

Uchinaaguchi ya muchikasashiga, shinee nuyatin naisa! (el uchinaaguchi es difícil, pero todo es posible!) 


\section{Anexo 4 \\ Categorización de la información}

PERSONAL, COMUNIDAD, HISTORIA Y ESTADISTICAS, PALABRAS, FRASES

Para el año 2100 se calcula que se perderán 3000 idiomas y, si no se hace nada, una de ellas será el uchinaaguchi

la población que lo considera como un idioma vivo es mayor de

75 años; aquellos que lo entienden y lo usan poco tienen entre

45 y 75 años, mientras que los menores a 45 usan solo el japonés.

"Si las comunidades de hablantes y los lingüistas no actúan inmediatamente, todas las lenguas de Okinawa habrán desaparecido para el 2050".

- 75,9\% se siente okinawense

- 87.5\% conoce menos de 25 palabras

- 62,5\% de becarios dice que estaría interesado en aprender si sabe que está en riesgo

El 71,9\% de los encuestados respondió que aprendieron uchinaaguchi durante la beca.

Ese era yo, un nikkei de tercera generación que iba a hacer que la cuarta no viva todo lo que yo he vivido

Las cosas se ponían feas en Japón y encontró en la migración una oportunidad y salió en búsqueda de un futuro mejor en Perú.

Mi oji no solo dejó su tierra sino que poco a poco también su lengua.

Mi oji, buscaba crear un puente entre su tierra natal y la tierra que ahora lo acogía.

1939 estalló la Segunda Guerra Mundial. Japón era aliado de Alemania e Italia, quienes eran enemigos de Estados Unidos. Por su parte, Perú hizo un pacto con el país americano, asi que los migrantes japoneses y su descendencia empezaron a ser perseguidos, 
hubieron saqueos, deportaciones a campos de concentración en EEUU, hubo violencia contra la comunidad como si nosotros tuviésemos la culpa. No solo se perdieron muchas cosas materiales, sino que también la herencia cultural se estancó. Se dejó de cantar y bailar las canciones en uchinaaguchi. Poco a poco, se dejó de hablar.

La migración okinawense fue 1906, cuando llegó el primer grupo de okinawenses para buscar nuevos horizontes. Poco a poco llegaron más, hasta ser el grupo más numeroso de japoneses en el Perú.

Esto hizo que los japoneses no se comunicaran ni en japonés, ni en ningún dialecto.

Hay de la prefectura de Okinawa (beca kenpi y Junior Study Tour) y las que ofrecen los mismos municipios (shi cho son).

Desde el año 1970, han viajado "cientos" de becarios. Algunos programas son de un mes, otros de 3 meses, otros de 6 y hasta de un año.

ya no tenemos oji, oba que nos enseñe.

una lengua que no es suya ni que les da ningún beneficio laboral o profesional, y por qué no, ni siquiera una satisfacción personal.

"Es a través de las canciones, los bailes y las ceremonias que los pueblos indígenas mantienen sus culturas y un sentido de identidad dentro del mundo." Esto también pasa en Perú.

Cada cierto tiempo hay eventos como el Icharibachoode, el Okinawa Matsuri, el Uchiná engeikai

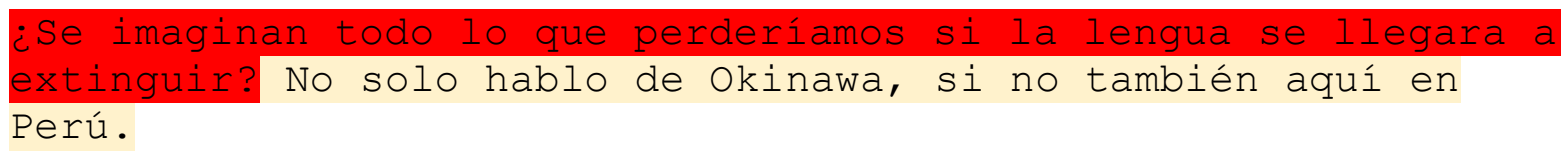

se pierde y no lo valoramos, nosotros vamos muriendo, también.

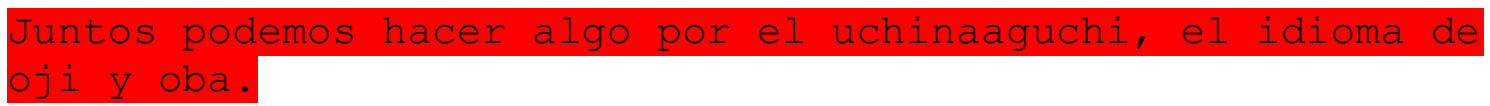


Umarejima nu kutuba washinnee, kunin washun (si olvidas la lengua de tu tierra natal, olvidarás también a tu tierra natal)

Me imagino cuántas veces se habrá gritado a sí mismo:

"Chibariyo" (Vamos, tu puedes).

$----$

Una de las cosas que más caracteriza Okinawa es el "Okaeri", bienvenido de vuelta a casa.

El "Icharibachode" (cuando nos conocemos somos hermanos)

"Kwatchi sabira", "Goyá","Dica dica", "Akisamio","Gachimayá"..

"Wanne Igei Kenji yaibin".

Haisai gusuyo, chuu uganabira, wanne Igei Kenji yaibin.

Yutasarugutu unigee sabira.

$---$

"mensoore" (bienvenido).

Unidos podemos. Chibariyo!

Yo quiero poner mi grano de arena desde la música. Varias de mis canciones tienen frases en uchinaaguchi como "ippe nifee debiru", "nuchidu takara", "icharibachoode", "haisai gusuyo", "wanne uchinanchu yaibin", entre otros. Cada vez que las canto, voy explicando sus significados y me interesa que las personas puedan conocerlas.

Uchinaaguchi ya muchikasashiga, shinee nuyatin naisa! (el uchinaaguchi es difícil, pero todo es posible!)

Representaba la historia, la cultura, el arte... representaba a Okinawa.

En una campaña de crowfunding, que se inició un día después del incendio, se recaudaron a los tres días el doble de la meta (2 millones de dólares). Al terminar la campaña (152 días después) se logró recaudar nueve veces más del objetivo.

Los uchinanchus han demostrado el orgullo por su identidad, por su historia, por sus raíces. 
Darnos cuenta que así como se hicieron esfuerzos para reconstruir el castillo, deben darse los esfuerzos para recuperar, mientras estemos a tiempo, la lengua de oji y oba. Si de aquí a unos años se extingue, ni por más que tengamos 9 millones de dólares, lograremos revivirla. No se tratará de 